Historic, Archive Document

Do not assume content reflects current scientific knowledge, policies, or practices. 



\subsection{3}

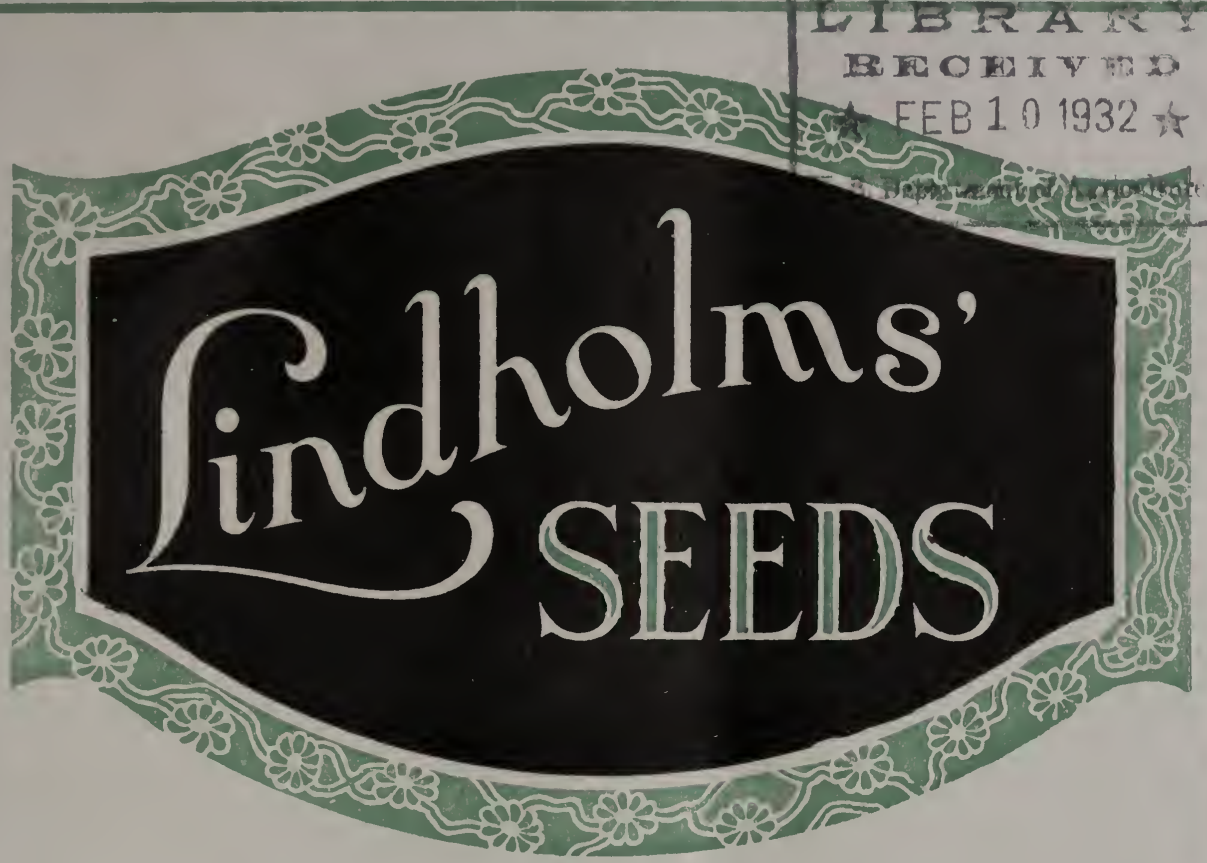

\section{MARKET GARDENERS' WHOLESALE}

1932

\section{CHAS. J. LINDHOLM}

Residence:

4133 Lyndale Ave. No.

Res. Phone: HYland 1966
Retail Store:

4170 Washington Ave. No.

Bus. Phone: HYland 7424 


\title{
Market Gardeners' Price List
}

STORE: HYLAND 7424

RESIDENCE: HYLAND 1966

\section{Plant Lindholm's Honest Seed for Profit}

\author{
JANUARY 1, 1932
}

In presenting this catalogue please accept my kindest thanks for your liberal patronage for past years.

Our constant aim is to furnish Seeds, Bulbs and Plants of Strictly First-Class Quality at the Lowest Possible Prices and our reputation for handling the best things for the garden and the farm is fully demonstrated every year by many testimonials which we receive and by the rapidly increasing demand for our goods.

I have taken great pains in the revision of my list to cut out all varieties which have no sale for the market gardener or shipper, and to catalogue only such varieties as I consider the best for the northwestern gardener.

I am keeping constantly on the watch for new varieties of vegetables and flowers which have proven in my judgment to be superior to any of the present products.

The list which follows contains, with very few exceptions, a complete list of all true varieties of vegetables and flowers, which have proven to be $O$. K.

Every precaution is taken to keep my stock free from mixture and I am very careful that everything I send out be true to name and will gladly replace such seed without charge that is not true to name.

We make a specialty of supplying market gardeners with the best strains of seeds that can be produced. We are always on the look-out for a better strain, and we spare no expense in securing seed stock of it.

\section{HOW MANY SEEDS WILL GROW?}

This is a question every gardener asks himself when sowing seeds. In order to sow or plant just the right quantity in a row or "hill" he ought to know what percentage of the seeds will germinate. Very few seeds are 100 per cent good. There are almost always a certain number of seeds that will not germinate. In some kinds the number is usually quite large and in others very small. It also varies very much according to the condition during the harvest and character of the season while growing.

To give the gardener this information so that he can tell just how many seeds to use, germination will be marked on the packets, if asked for.

\section{WHAT WE GUARANTEE}

We assume all risk of the seeds, plants, etc., we sell, reaching the purchaser in good condition. Should any seed bought of us fail to grow under favorable conditions, or not prove to be true to name, we will refund the money paid for them.

If seeds or plants are lost or destroyed while on the way to the purchaser, we will replace them without charge, or refund the money paid for them at our option.

\section{WHAT WE DO NOT GUARANTEE}

We do not guarantee that the purchaser will get a crop from the seeds, nor will we be in any way responsible for loss of a crop. We are willing to refund the money paid for the seeds if they are not as represented, but we do not assume any responsibility for the crop.

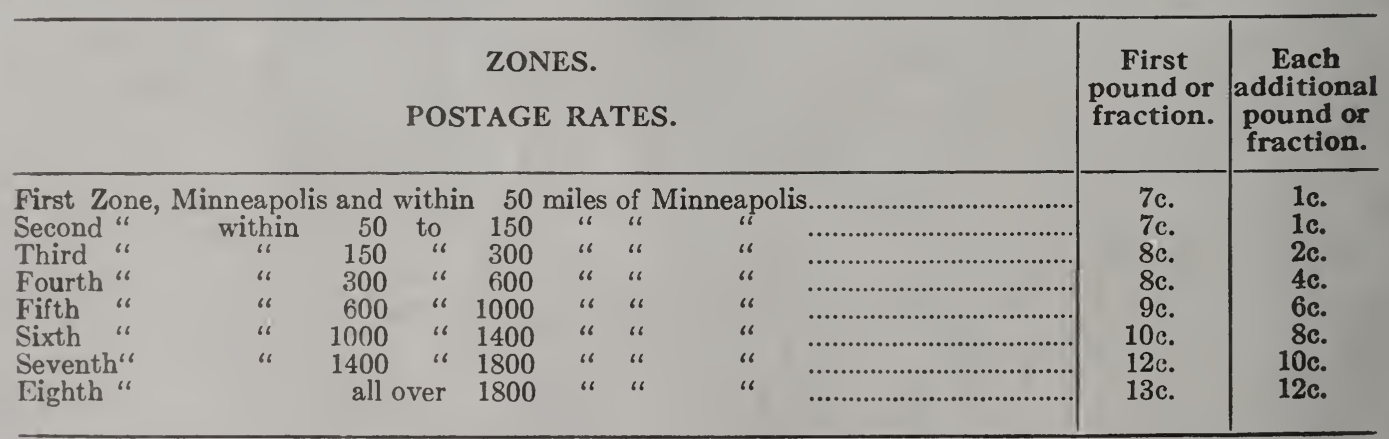




\section{Lindholm's Novelties for 1932}

After careful trial and comparison of relative merit, we offer a number of outstanding new vegetable strains. Each one is a leader in its class. You will find these to show decided improvement over strains offered previously. They are all worthy and of the highest quality. We unhesitatingly recommend them and hope you will try them.

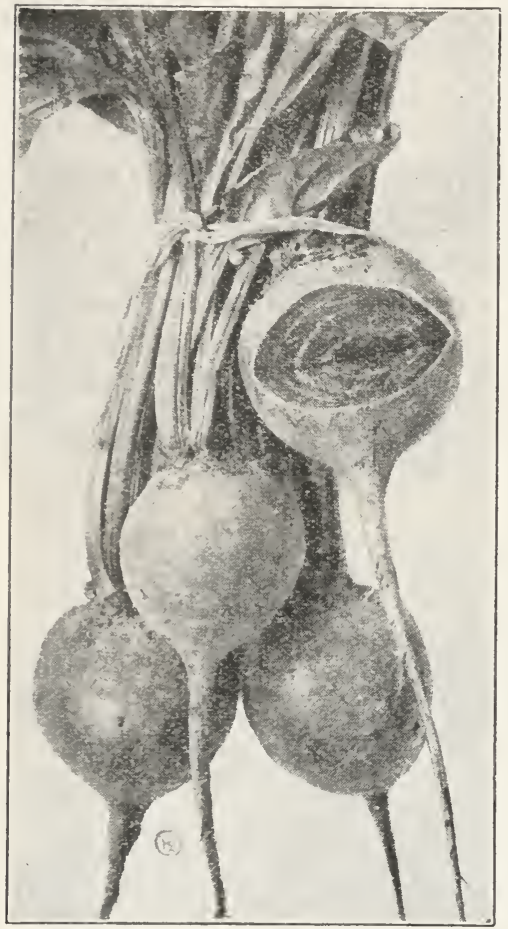

In planting Beets, Carrots and Onions I would recommend the use of Potash liberally, either alone or in a fertilizer which I believe will help toward a better color in the roots. We often time h e a $r$ complaint that the Beets are white streaks inside and we find that those who use Potash and plant the same seed are never troubled about that. the Beets will be white streaks in and this will also apply to Carrots and Onions.

B I R D S E E D - We carry a nice clean stock of Canary, Rape and Hemp Seed for Canaries, and Sunflower Seed for Parrots. This is much cleaner, more economical, and better in every way than the ordinary mixed bi r d sced put up in packages.

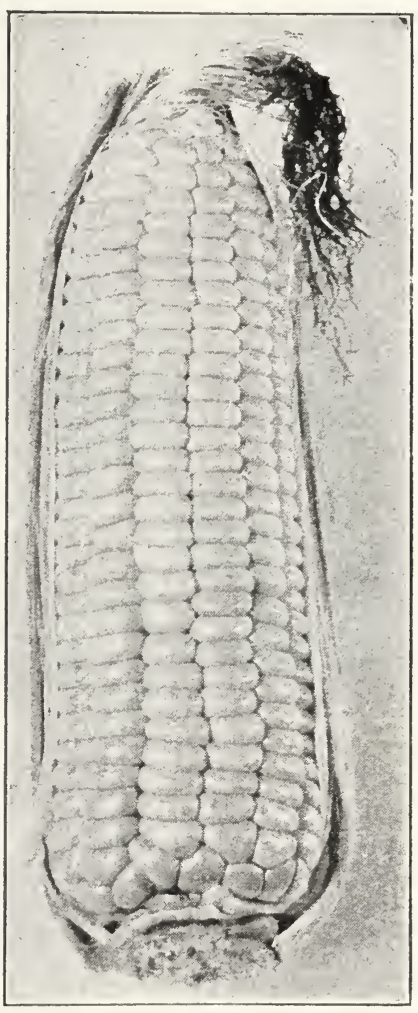

BEET DETROIT DARK RED SELECT STRAIN-This strain of Detroit Dark Red comes from the best seed grower in Ame-ica. It is as perfect as it can ever be grown. Roots are globe shaped. Very smooth and of medium size. Skin dark red. Flesh intense deep red withcut zones. Very sweet and tender. 1 oz., $10 \mathrm{c} ; 1 / 4$ lb., $25 \mathrm{c} ; 1$ lb., $85 \mathrm{c}$.

If you are interested to make some real money from a very small acreage plant the Early Gem Sweet Corn and the Extra Early Sunrise Musk Melon they surely are money makers. The Early Gem is the earliest of all Sweet Corn and the Sunrise Musk Melon is the earliest of all yellow meated melons out and anything that is early and at the same time good will always bring a good price.
EARLY GEM SWEET CORN-Decidedly the earliest and best of all early Golden Bantam type developed by Professor A. F. Yeager of the North Dakota Experiment Station. The plant growth is distinctly dwarf, three or three and $a$ half feet in height, and the ears are borne close to the ground. It is a productive sort can be planted more closely than most varieties. The ears are eight to ten rows and the color is golden yellow. It is three to five days earlier than the Early Dow. We are sure market gardeners will find this a very profitable Corn as it can be put on the market before any other variety. We have only a limited amount of it this year. So we can not sell more than 12 Ibs. to a customer. 1 lb., 35c; 3 lbs., $\$ 1.00$ : 12 lhs., $\$ 3.50$. 


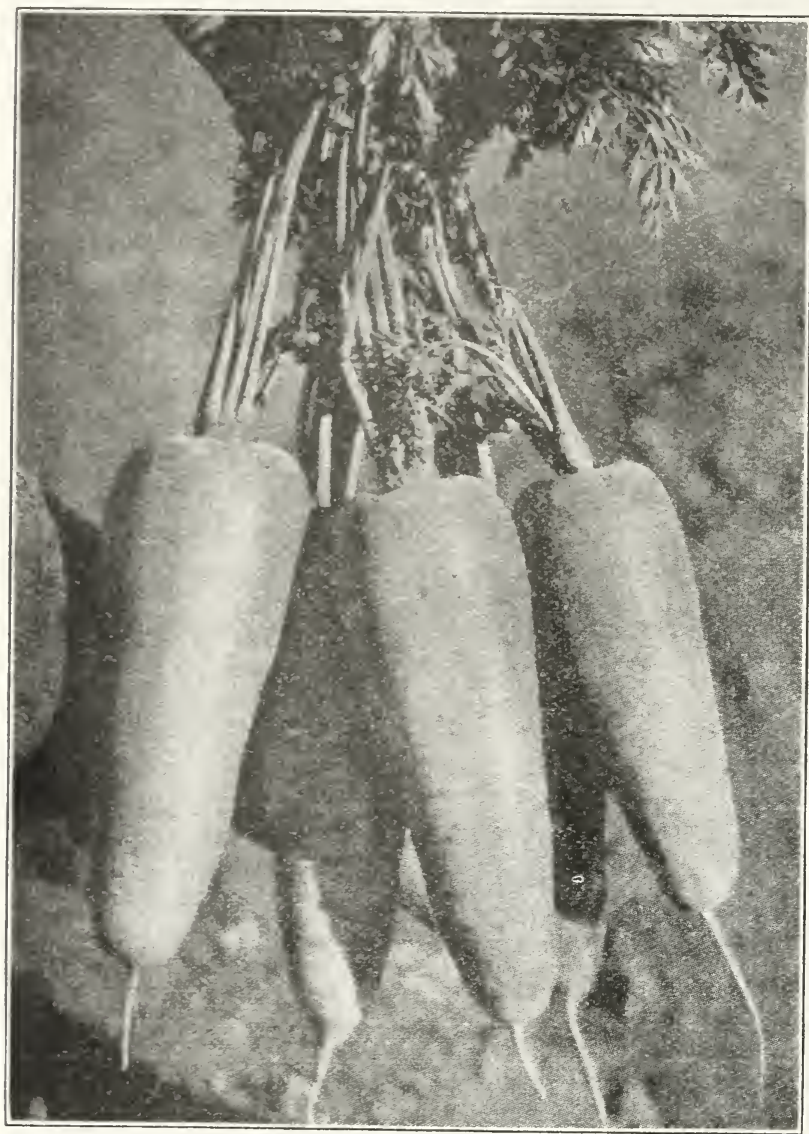

RICE'S CORELESS CARROT -The most strikingly handsome a rly carrot we are acquainted with. Roots are deep orange in color, exceptionally smooth, cylindrical in form, 7 inches in length by $1 \frac{1}{2}$ inches in diameter, free from woody heart or core and of the highest quality. The flesh is crisp and sweet. We predict it will be a wonderful market carrot for bunching and should be raised on peat soil. 1 oz., 15c; 1/4 lb., 35c; 1 lb., \$1.25.

Rice's Coreless Carrot

\section{CUCUMBER}

LONGFELLOW - An excellent, long, slender, dark gre e $\mathrm{n}$ variety equally desirable for greenhouse forcing or out-door culture, and an ideal type for the private garden or as a "straight pack" variety for shipment to market. It measures 12 to 14 inches long by $2 \frac{1}{2}$ inches in diameter. A good healthy grower, very productive, and is fairly early. $1 \mathrm{oz} ., 20 \mathrm{c} ; 1 / 4 \mathrm{lb} ., 60 \mathrm{c} ; 1 \mathrm{lb} ., \$ 2.00$.

ONION. RIVERSIDE SWEET SPANISHThis is a California grown strain of the Spanish Onion, it grows larger than the American prizetaker and does not produce the stiff necks usual in the Spanish type. It is the most popular Onion in southern California and when grown as a specimen attains enormous size, 3 to 4 pounds. If started very early in hot bed it will produce a mammoth Onion the first season. 1 oz., $30 \mathrm{c} ; 1 / 4 \mathrm{lb} ., 85 \mathrm{c}$; $1 \mathrm{lb} ., \$ 3.00$.

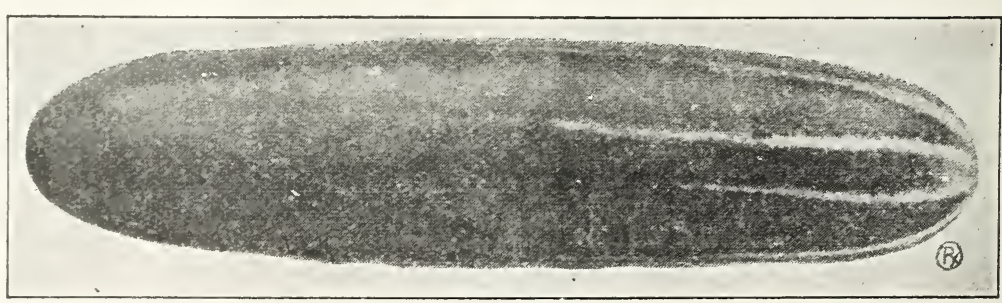

Longfellow

We also have in stock the following new varie ${ }^{t i e s}$ of Watermelons. 1 oz., $10 \mathrm{c}$; $1 / 4$ lb., 30c; 1 lb., $\$ 1.00$.

NEW CHILEAN-Attractive, of medium size, nearly round, skin deep green, faintly mottled and striped, stripe of brighter shade.

STONE MOUNTAIN-A very large, nearly round or "blocky" melon of high quality. Rind fairly tough, dark green; flesh sweet, rich scarlet, with few seeds; very prolific. 
CAULIFLOWER (Snowdrift)-Snowdrift is a more vigorous type of the Snowball class and selected to produce a larger head than Snowball. Without losing in earliness, very robust, and strong growing this new strain will mature with great evenness and harvesting may be completed in 120 days after date of sowing. The pure white heads are remarkable for their great depth and unexcelled white color. Also heads in which small green leaves appear will be sought in vain. The foliage is some-

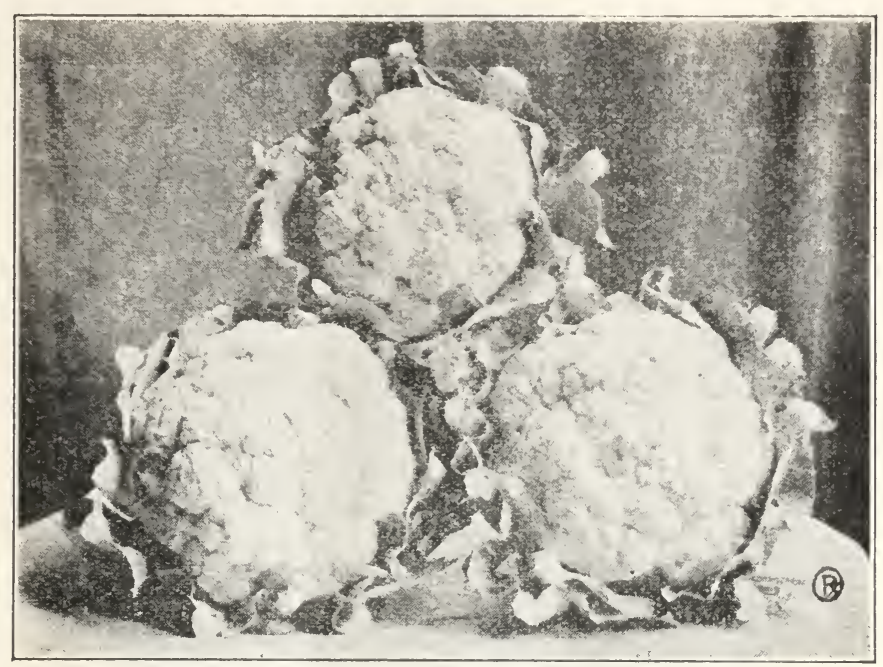
what larger than of Snow-

ball and the inner-leaves are perfect protecting the head until nearly full grown. This strain comes from one of the best Cauliflower growers in Europe. We are sincere in believing that Snowdrift ranks as one of the very superior stocks of Cauliflower available anywhere at any price. 1 oz., $\$ 2.00 ; 2$ oz., $\$ 3.75 ; 4$ oz., $\$ 7.00$.

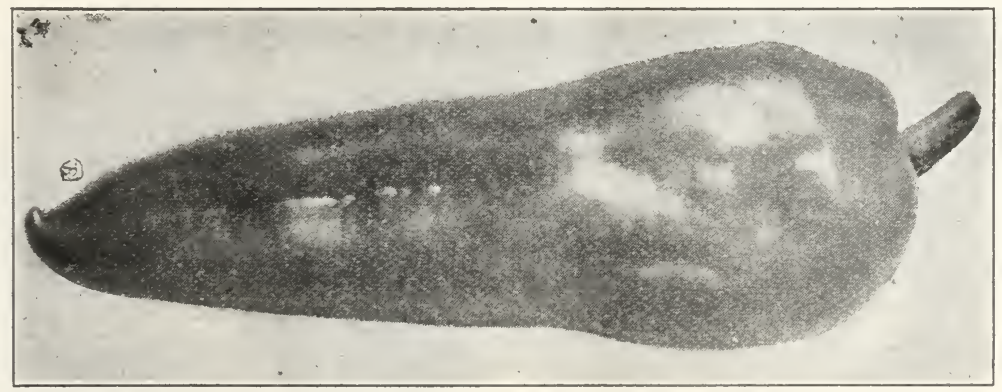

HUNGARIAN YELLOW PEPPERFruit very pungent, 5 to $6 \mathrm{in}$. in length, rather slender and tapering to a somewhat twisted point. Waxy canary yellow in color, turning crimson at maturity; very prolific. Also known as Bulgarian Yellow Wax.

We think in time it will take the place of long Thick Red. 1 oz., 50c; $1 / 2 \mathrm{lb}$., $\$ 1.75$.

We offer our customers the choicest stocks of Sweet Corn at very low prices, quality considered.
COCOZELLE (Italian Vegetable Marrow)-A bush summer variety. Fruits oblong, ribbed, 12-16 inches in length. Color dark green marbled with yellow and dark green stripes. Very fine flavor. 1 oz., 15c; 1/4 lb., 35c; 1 lb., \$1.25.

PEPPER. California Wonder-This new variety resembles Chinese Giant in shape, but has much thicker flesh. The fruit will average 4 inches in diameter at the top, tapering slightly. It matures its fruit somewhat earlier than Chinese Giant and is very prolific. Color glossy dark green, turning to crimson. Pkt., $15 \mathrm{c} ; 1$ oz., $50 \mathrm{c}$. 


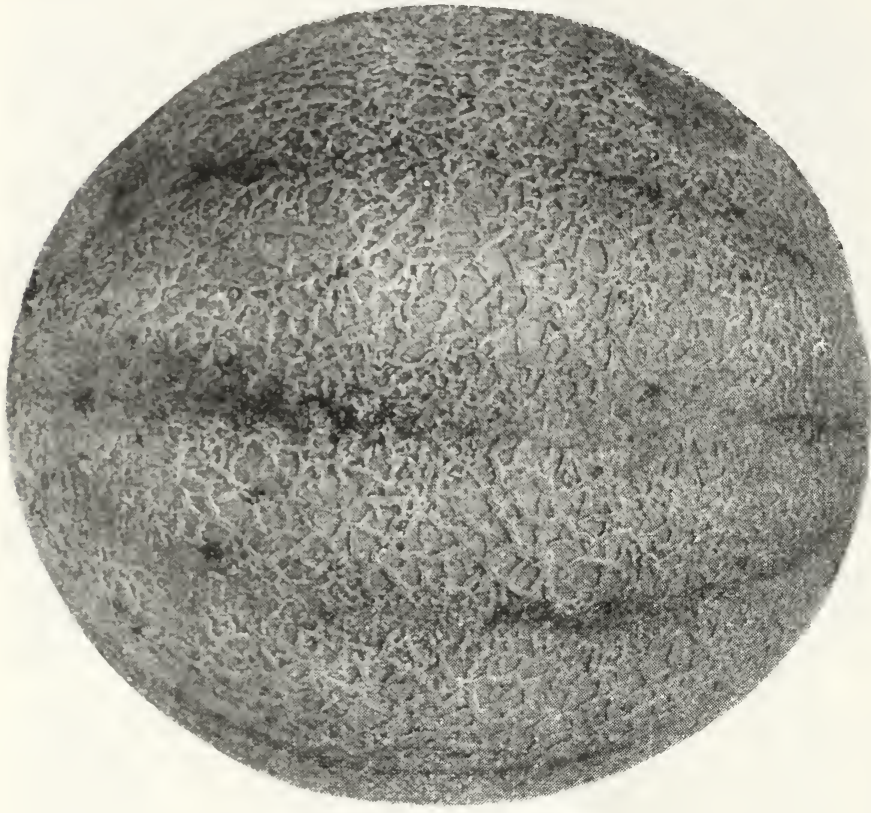

Extra Early Sunrise
MUSK MELON - EXTR A EARLY SUNRISE - This new Melon is a wonder. It will certainly be the best money maker Melon on this market for years to come. This Melon is very early, it ripens as early as the Lake Champlain which is considered the earliest of all the yellow meated melons grown. The melons grow quite large, average 5 lbs, or more and are of oval shape, light golden yellow, and covered with fine netting; the flesh is firm deep orange yellow, and of high flavor, very sweet. The combination of earliness, high quality and good size, is not found in any other melon on this market. Growers will do well to give it a trial. All orders will be filled as received until supply of seed has been exhausted and would advise that if you are interested in obtaining a quantity of this seed that you get your order in at the earliest possible date as the supply is limited. $1 \mathrm{oz}$., $20 \mathrm{c} ; 1 / 4$ lb., 60c; 1 lb., $\$ 2.00$.
SUGAR ROCK MUSK MELON-This new melon has proved to be a very valuable variety, it is one of the most delicious melons we have ever eaten. Every melon is of high flavor and very sweet. Medium size, about twenty-five melons to a bushel basket. Round as a ball, and covered with heavy coarse netting. The fruit is of deep orange color. Firm and of good thickness. The color of the melon is very light green turning when ripe to a light golden yellow. The melon ripens medium early and the vines are very productive. An excellent melon for the home garden and very profitable for market and shipping. Its handsome appearance and high quality will make it command good prices in any market. The introducers stock put up in $1 / 2 \mathrm{lb}$. packages only. $1 / 2$ lb., $\$ 2.00 ; 1$ lb., $\$ 3.75$.

Seed in bulk grown from the introducers stock. 1 oz., 15c; 1/4 lb., 40c; 1 lb., \$1.50.

FEWER BUT BETTER VARIETIES-The consumer wants the very best qualities not a great many sorts, therefore we are concentrating our energy on a limited number of varieties and this enables us to give the closest attention to the growing of our seeds.

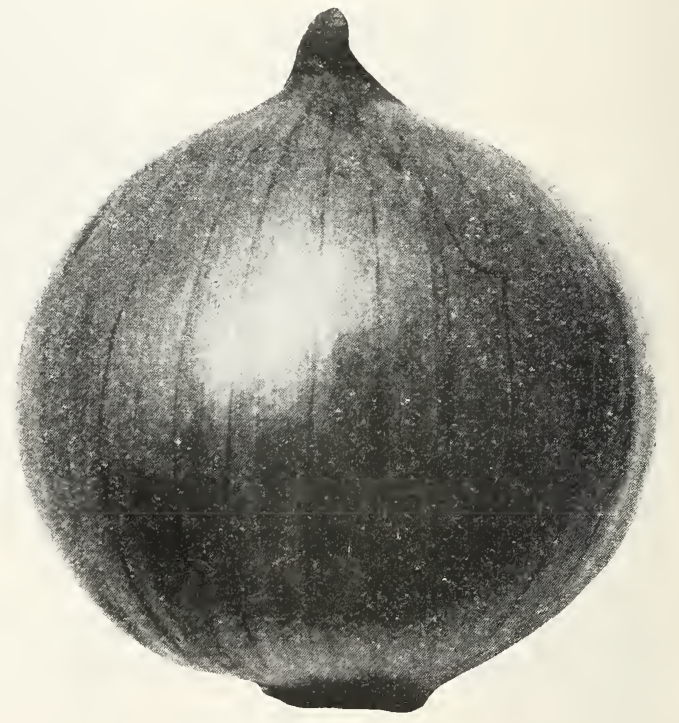

Extra Early Yellow

ONION. EXTRA EARLY YELLOW-Half way between globe and flat. Ripens even three weeks earlier than yellow globe. It is deep yellow in color, very hard and solid; the flesh is crisp and very mild, of extra good quality. 1 oz., 25c; $1 / 4$ lb., 70c; 1 lb., \$2.50. 
WATERMELON-Black Seeded Angeleno. The most attractive in appearance of all watermelons. Its large size, beautiful dark green rind with a tinge of gold showing through the green, no other variety compares with the Angeleno in its bright red flesh, red to the rind and entirely free from fibre. Simply melts if the picker will observe the gold shining through the green as soon as it is ripe. He need never pick an unripe melon. This will surely be the best selling watermelon on this market and also on the roadside stand. Oz., 10c; $1 / 4$ lb., 25c; 1 lb., 90c.

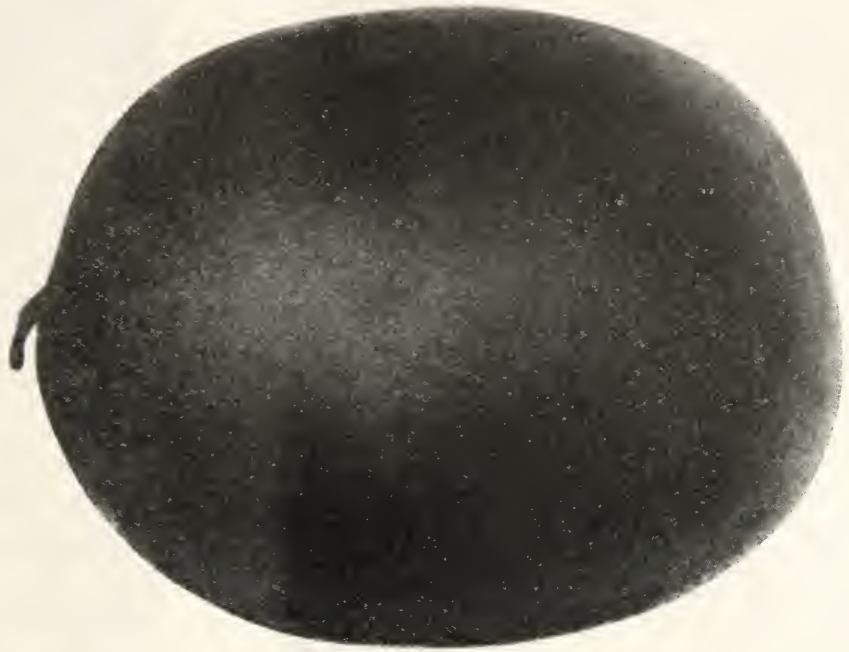

Angeleno

SQUASH-Giant yellow summer straightneck. A selection from the crookneck Squash but with a straight rather than a crooked neck, and thus being more easily packed for shipment. Fruits intensely warted 18 to 20 in che s long. Deep orange in color with a thick, meaty neck. The flesh is a beautiful light yellow. It is sweet and buttery. Oz., 10c; $1 / 4$ lb., 35c; 1 lb., $\$ 1.25$.

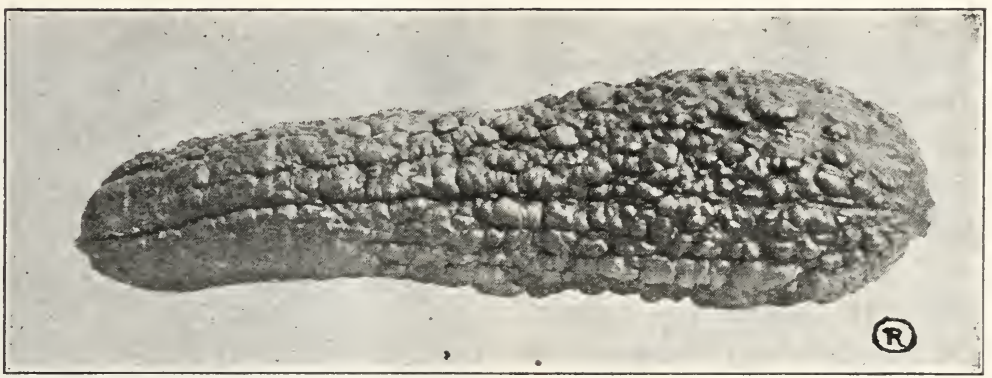

SPINACH-NOBEL, GIANT LEAVED-By far the best of the so-called smooth leaved sorts. It produces a large mass of rather smooth, very thick, rounded leaves, of enormous size and although it is a very quick grower, it stands very long before bolting. Being a very shy seeder it is impossible to grow Nobel at the prices of the old varieties but though there is some difference in price one will seldom get better value for that money. Nobel is an ideal variety for truckers and for canners. When using Nobel there is no longer any need for listing the older sorts of this type. Such as improved thick leaved viroflay, large round leaved, Flanders broad leaved. 1 lb., 35c; 10 lbs., $\$ 3.00$.
SPINACH. EXTRA EARLY DARK GREEN BLOOMSDALE-New. A better and darker strain of the well known early Bloomsdale. Market gardeners are very much impressed with this attractive selection. Its darker color gives the plants a fresh appearance for a longer time after being cut than ordinary Bloomsdale. It remains much longer in marketable condition than the old savoy-leaved. Being quite as early it entirely displaces the old strain. 1 lb., 30c; 10 lbs., $\$ 2.50 ; 100 \mathrm{lbs}$., $\$ 22.50$.

The varieties on these few pages are among the best of their respective classes. Most of them are kinds which we have introduced to the trade and of which we have very carefully bred strains. Owing to the fact that we are taking the greatest care to have them of the very best quality. 


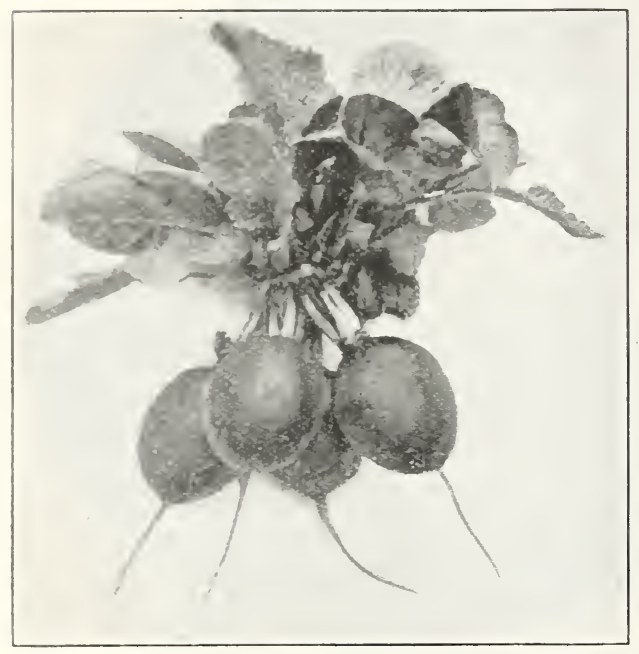

Glowing Ball
RADISH-Glowing Ball. New. (Extra Early Forcing Variety)-We have great pleasure in offering you "Glowing Ball" a splendid forcing Radish which is a striking advance over the present scarlet forcing varieties such as Saxa, Nonplus Ultra, Express, Scarlet Button and others.

We never came across a Radish of such an unusual brilliant color. Bright fiery scarlet-red, it has a glow all its own. When pulling these Radish it looks like getting coals of fire out of the ground. This color will never fail to attract the attention of the grower as well as of the consumer, it has a small top and the shape is perfect round. $1 \mathrm{oz} ., 10 \mathrm{c} ; 4 \mathrm{oz}$, $30 \mathrm{c} ; 1 \mathrm{lb} ., \$ 1.00$.

RADISH. Scarlet Globe-Special outdoor strain (with more top) this new strain of Scarlet Globe Radish which will produce somewhat larger tops than our regular Scarlet Globe. It sometimes occurs that the tops of the latter variety when sown outside remain too short so that they do not bunch well for shipment. This demand has prompted the grower to select a strain with somewhat larger tops and we are glad to be able to offer it to the trade now. This Radish differs from our regular strain only in the length of the tops. As for the rest it is quite as perfect in every respect. It is unsurpassed for outdoors truckers work. $1 \mathrm{lb}$, $65 \mathrm{c} ; 10$ lbs., $\$ 6.00 ; 50$ lbs. $\$ 27.50$.

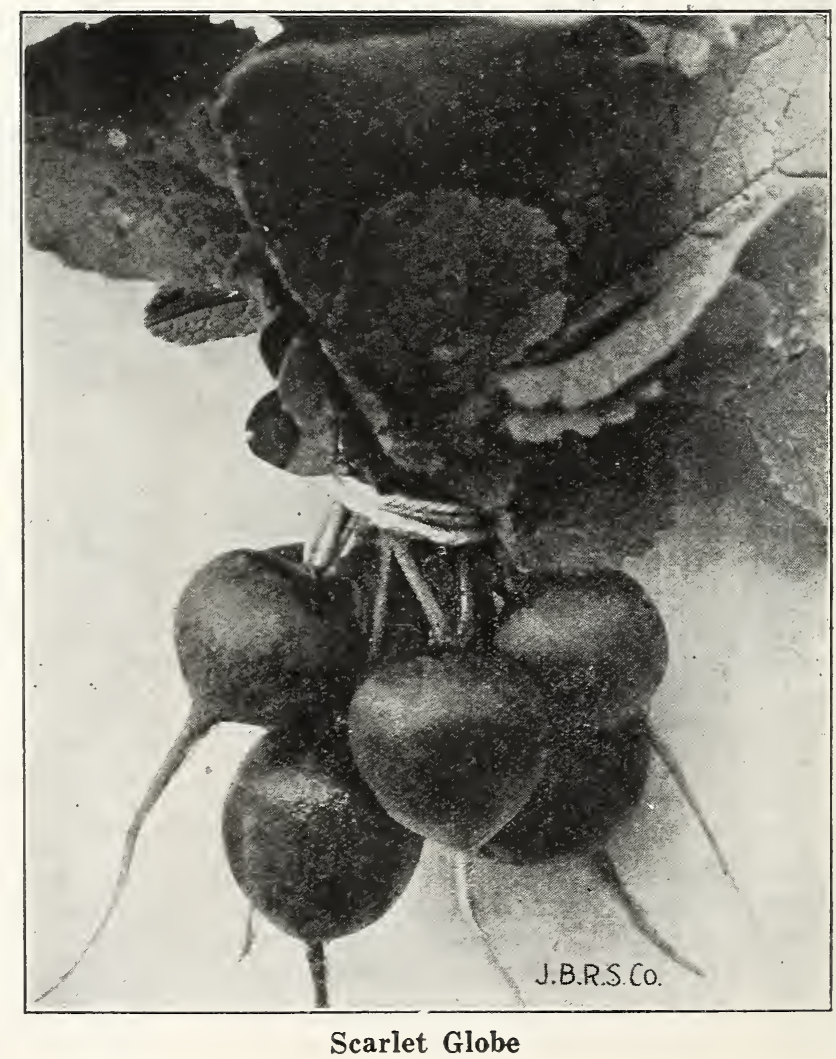


RADISH-Bicolor. New-An increasing demand on some markets for a Radish with a larger portion of white than sparkler, has prompted us to introduce this new Radish to the trade on which the white extends from the tip up to the middle of the root, or even a little farther. Upper half is a vivid scarlet. In shape it is quite similar to our Sparkler. A Radish of very attractive appearance, which has always proved to be a favorite with truckers. 1 oz., 10c; 4 oz., 20c; 1 lb., 6 sc.

RADISH - New crimson giant from (transplanted strain) the stock we offer now is pure ball-shaped, has a bright red color and is exceedingly uniform. It grows twice the size of Scarlet Globe, is only a few days later and of excellent quality as it stands longer than any other variety without becoming pithy. 1 oz., 10c; 4 oz., 20c; 1 lb., 65 c.

C A B B A G E-Ferry's Hollander-A strain of the Danish Ballhead type. Sure heading, very solid and one of the very best keepers. This is particularly desirable for distant markets or for late spring use. The plants are vigorous and compact with short stems. They are exceedingly hardy in resisting cold and stand dry weather well. The leaves are distinctly upright in growth-few but rather large, long and narrow, thick, smooth, bluish green covered with whitish bloom. The heads are medium sized, round, exceptionally solid and stand shipment better than any other late sort. This is the pure strain of Ferry's own growing and no substitute. 1 oz., 50c; $1 / 4$ lb.. $\$ 1.75 ; 1$ lb., $\$ 6.00$.

SQUASH-Banana-An excellent winter squash with a superior flavor. The fruit is commonly 18 to 24 inches long and about 7 inches in diameter. The skin is gray-blue and not as hard as the Hubbards, while the flesh is fine grained. deep yellow, dry, sweet and of prime quality. It keeps very well into the winter. 1 oz., $10 \mathrm{c} ; 1 / 4$ lb., 35c; $1 \mathrm{lb}$., $\$ 1.25$.
A DELICIOUS BEAN-“Tendergreen" -If you want really delicious tender, fine flavored, early snap beans plant some of the Tendergreen. There is no bean of its class that is of quite as fine quality. The pods are long, round as a pencil, very meaty and of light green color. They mature early. Pods about 6 inches long, stringless, very productive. Market growers will find this the most profitable green podded bean. It is not often that so many good qualities are combined in one variety. $1 \mathrm{lb} ., 30 \mathrm{c} ; 15$ lbs., \$3.75.

BEANS - Black Valentine - Beautiful large pods about 6 inches long. Slender, nearly round and almost straight, fine grained, dark green in color. A very early, productive, profitable gardener's variety. $1 \mathrm{lb.}, 25 \mathrm{c} ; 1.5 \mathrm{lbs} ., \$ 3.00 ; 30 \mathrm{lbs}$, $\$ 5.40$.

\section{When You Buy Seeds}

\section{YOU HAVE A RIGHT TO KNOW HOW MANY ARE GOOD}

Each lot of seed which we raise or have raised for us is tested either in soil or in a germinating apparatus and the number of seeds which germinate out of one hundred seeds tested is put on the label.

With this information you can tell just how thick to sow the seed to get the right number of plants in the row and avoid wasting the seed. 
TOM A TO. BONNY BEST. (Extra Selected)-An exceptionally high-class strain prod u c in $g$ remarkably heavy yields of uniformly perfect large. Smooth, round intense scarlet fruits very early in the season. This seed, sele cted with infinite care at great cost, will produce very fancy attract ive Tomatoes commanding top prices.

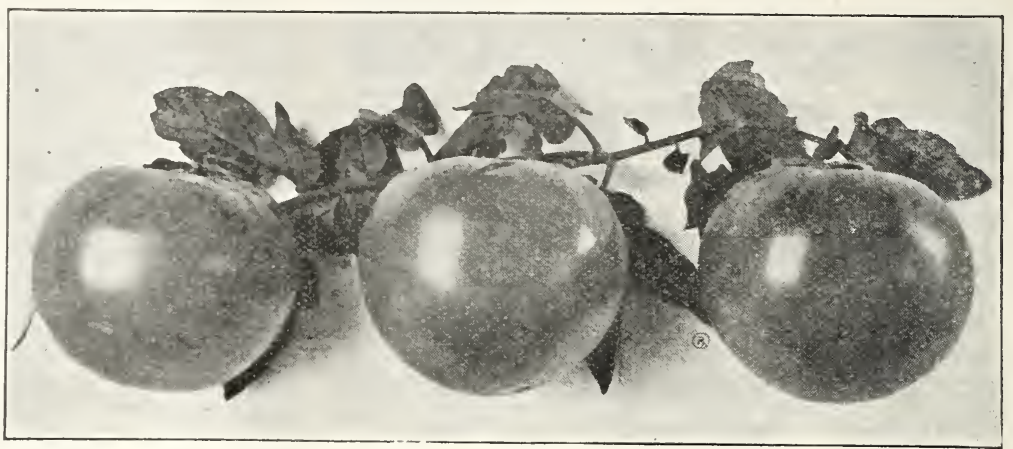

The old tendency toward cracking of the skin has largely been overcome. The plants produce enormous crops which continue to ripen until the vines are killed by frost. The Tomatoes are large, as smooth as an apple and of a deep scarlet color which extends right up to the stem without any green tinge. This seed is raised by $H$. P. Langdon and it is the best seed that can be had no matter how much you pay for it. $1 / 2$ oz., $\$ 1.15 ; 1$ oz., $\$ 2.00$; $1 / 4$ lb., $\$ 7.00$.

\section{CROP FAILURE}

PARSLEY - EMERALD NEW - This new strain combines a very rich dark green color with extreme curliness. It has a dwarf habit and a most attractive appearance. No other strain equals "Emerald" and we do not hesitate in recommending it as the best of all curled parsley-varieties. Oz., 15c; 1/4 lb., 50c; 1 lb., $\$ 1.60$.

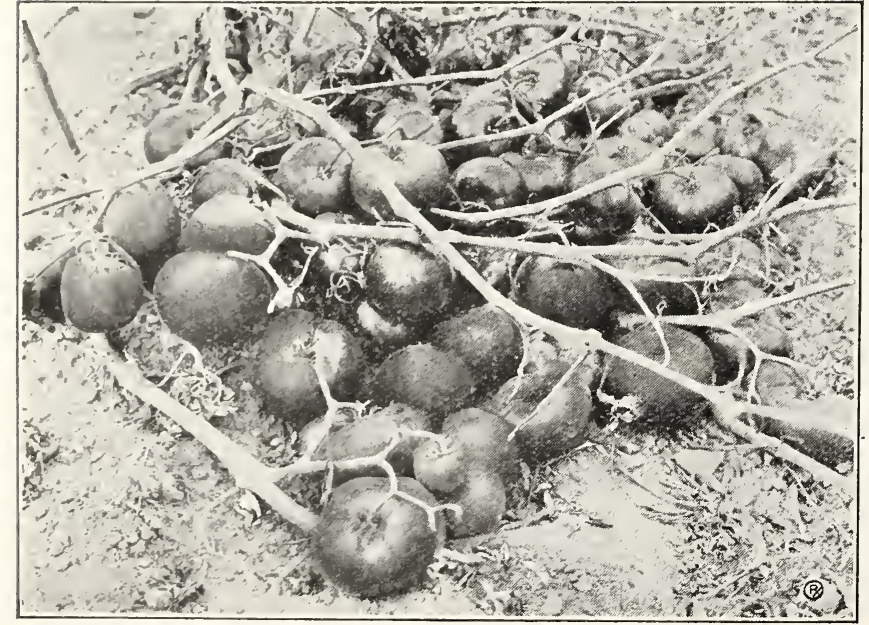

Bonny Best

BREAK O' DAY TOMATO-This new tomato resulted from a cross between Earliana and Marglobe. It retains the vigor of vine and globe shope of the Marglobe, combined with the earliness of the Earliana. The fruit is as round and smooth as an apple, deep orange red and colored well up to the stem. Within the color is deep red and flesh is very solid and remarkably few seeds. The vines are of spreading habit and carry an abundance of fruit and resist blight well. We are sure gardeners will find it a very desirable variety. It is not only very early but also of the highest quality for table use or canning. $1 \mathrm{oz}$., $75 \mathrm{c} ; 4$ oz., $\$ 2.50$.

Earliana

NEW EARLIANA TOMATOLindholms Special Strain. This is the earliest market variety of which we know. It is smooth, quite deep and firm. Seed cells are small and with thick walls. The color is a good hearty red extending for an Earliana, remarkably well back toward the stem. The vines, though compact, are vigorous and prolific. Gardeners find this a most profitable Tomato to raise. The early crop brings high prices and the fruit that ripens later is of such good shape and color that it brings almost as much as the later varieties. The seed of this improved strain is not very plentiful so it will command a high price. $1 / 2$ oz., 90c; $1 \mathrm{oz} ., \$ 1.50$. 


\section{Lindholm's Reliable Vegetable Seeds}

\section{ASPARAGUS}

CULTURE-Sow early in Spring in rows one foot apart; when one year old the roots may be taken up and transplanted in permanent beds, which should be made by taking out the soil to a depth of about 20 inches; fill in with six inches of well rotted stable manure, then six inches of soil somewhat firmed. Place the roots on the same about 18 inches apart and 4 to 5 feet between the rows with the roots well spread out, and cover so that the crown will be about four inches below the surface. Keep the surface well raked to keep down the weeds until the shoots appear.

Asparagus from the home garden is one of the most delicious and earliest of crops. It may be grown in any deep, rich soil, either from seed or roots. One ounce of seed for 40 feet of drill; 2 pounds of seed produces enough roots for 1 acre.

MARTHA WASHINGTON-The most thoroughly rust-resistant variety. Originated at the plant breeding station of the U. S. Department of Agriculture at Washington. This strain is not only practically free from rust and other diseases but it is also larger and niore vigorous than the common kinds. The stalks are large, deep green with purple tips.

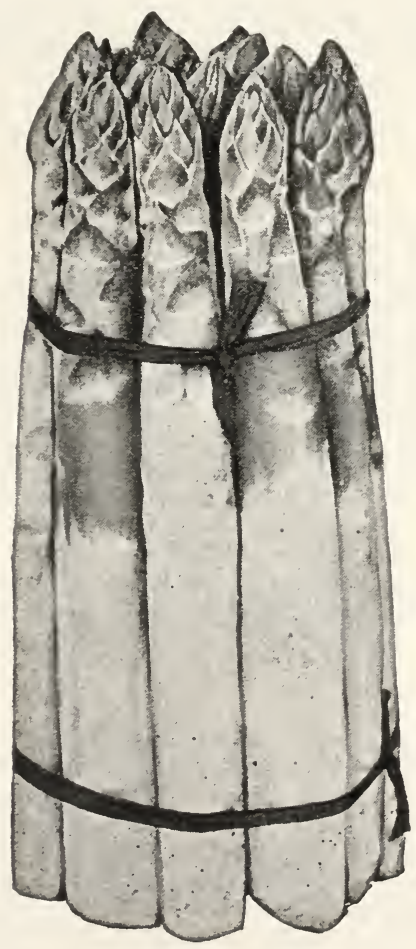

Mary Washington
GIANT WASHINGTON ASPARAGUS-Giant Washington Asparagus is a combination of female plants Mary and Martha, together with other selected female plants approved by the U. S. Department of Agriculture, all bred through the male plant Washington. This is a quality asparagus and under good conditions will produce a superior crop of earlier and larger stalks and possessing good rust resistance. This variety will yield more money per acre than all other sorts, as no other variety is as good.

MARY WASHINGTON-There are several strains of Asparagus originated by Prof. Norton, of the U. S. Department of Agriculture. The original strain was called Washington, another selection Martha Washington, and another Mary Washington. The Mary is considered the best strain, as the shoots are larger and grow more rapidly than the other kinds. This variety is so vigorous that seedlings grow considerably larger the first year and can easily be distinguished when growing by the side of other varieties by their taller growth. The stalks are very thick and grow unusually tall without branching. The color is deep green with purple tips.

CONOVER'S COLOSSAL - In old standard and more largely grown than any other sort. It is unsurpassed in flavor. Prices, by mail, postpaid.

PALMEITO - This is one of the best varieties It. produces large, light green shoots early in the season, and is said to be less subjert to rust than any other kind.

\begin{tabular}{|lrrr|}
\hline \multicolumn{4}{c|}{ ASPARAGUS } \\
& $1-0 z$. & 4 -oz. & 1 -lb. \\
Giant Washington & $\$ 0.10$ & $\$ 0.30$ & $\$ 1.00$ \\
Mary Washington & .10 & .30 & 1.00 \\
Martha Washington & .10 & .30 & 1.00 \\
Conover's Colossal & .10 & .20 & .75 \\
Palmetto & .10 & .20 & .75 \\
\hline
\end{tabular}




\section{BEETS}

One ounce will sow 50 feet of drill; 6 lbs. for an acre.

One of the earliest vegetables the garden yields and one of the first to be sown or planted into the garden. For an extra early supply, sow seeds in a hotbed or cold frame by middle of March. Be sure to press the soil in firm contact with the seeds to insure prompt and even germination. By middle of April, plants will be 4 inches tall, when they should be set out in the garden in rows 18 inches apart, with the seedlings four inches apart in the row. For a continuous supply throughout the season, make the first sowing outdoors along middle of April, and again every two weeks up to August 1st. To be most palatable, Beets should be eaten while quite young, when the bulbs average two inches in diameter, no more. To secure a good start outdoors, the gardener should always walk over the rows after the seeds are sown. To secure a uniformly well shaped product, seedlings should be thinned out to stand 3 to 4 inches apart in the row. Those that are pulled up will make good greens or may be transplanted into other rows.

\section{BEET SEED GROWING}

To particular gardeners who want something choice for a critical market it will be interesting to know that our growers are continually selecting perfect shaped beets of our two leading sorts.

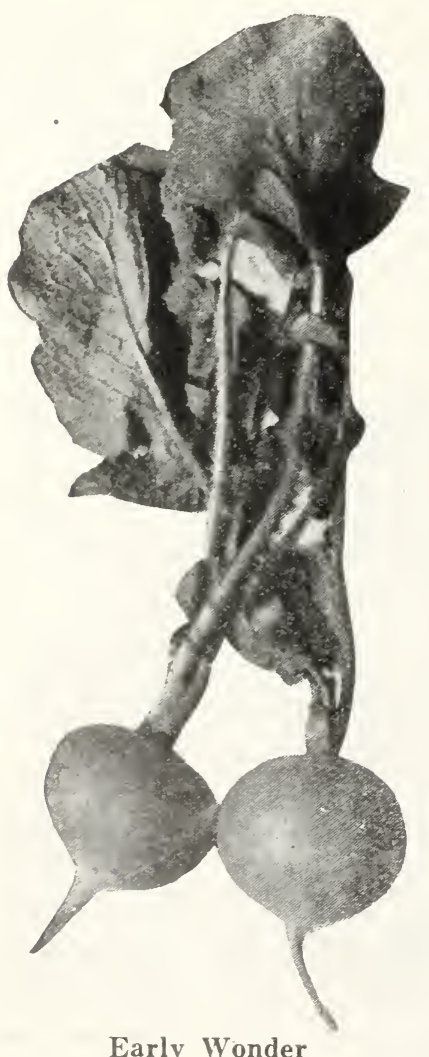

Early Wonder
EARLY WONDER AND DETROIT DARK RED BEET-For the size of the top and shape of the Beet and their color. To test for color, each beet that goes into our stock seed selection receives a single gash on the top of the beet with the knife, and if it shows dark red it is accepted and if it shows a light color, it is rejected.

EARLY WONDER-This is an early beet with a very small tap root, small top and exceptionally dark red color. It matures very evenly so that when you commence to pull on a piece of beets you can pull the pieces clean. The fact of this beet having such a small top makes it a very small seed, therefore a light yielder in seed, making it cost a trifle more than other varieties, but it is well worth the cost. Roots are globular and peculiarly smooth; color is of blood red, very crisp, tender, finegrained and sweet, remaining so for a long time. We believe this excellent new stock will produce a crop more uniform in shape, color and quality than any other beet ever placed in the hands of the trucker. To retain earliness it should be grown with greatest care-it is worth the attention it demands; market gardeners have proved the Early Wonder Beet is splendid for bunching, attractive in size and excellent in general appearance.

EXTRA EARLY SUNRISE-Is remarkable for its uniform shape, deep-colored flesh, and fine sweet flavor. The globeshaped roots are smooth and free from any woody fiber. Both skin and flesh are of an unusually deep rich red, this intensity of color being retained when cooked, making the beets most attractive for both canning and pickling. Although very early (quickly reaching a diameter of 2 inches), if left growing, the larger roots retain their fine flavor and deep coloring. Fully grown roots measure 3 inches across. Excellent for the home garden, and one of the best varieties for market on account of its earliness. 


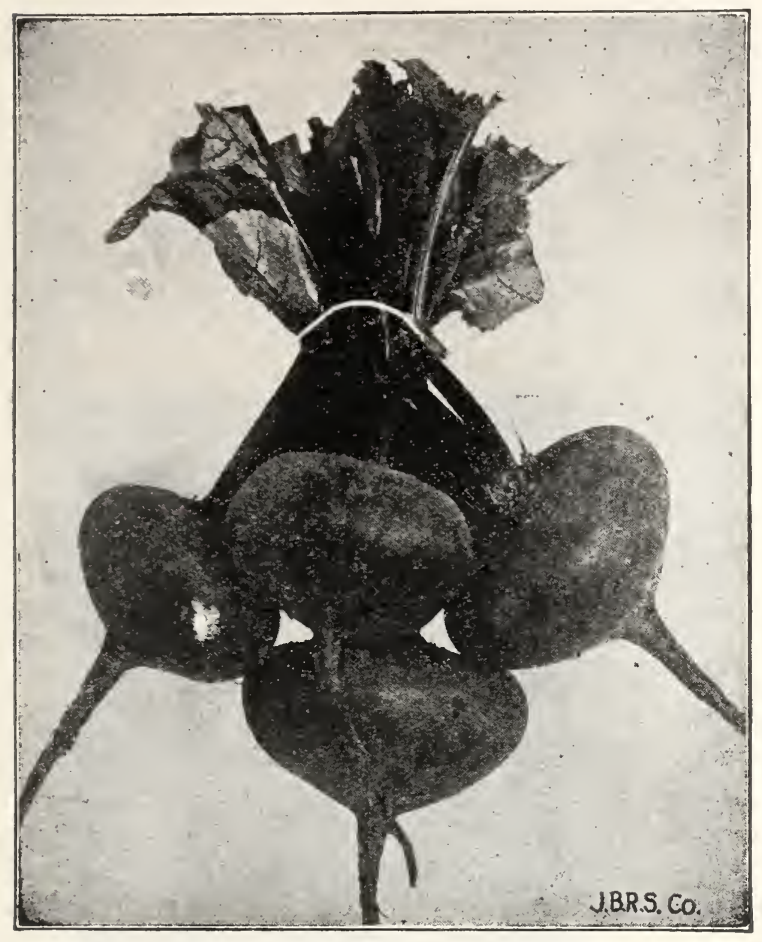

Crosby's Improved Egyptian
CROSBY'S IMPROVED EGYPTIANThis is the best extra early variety grown for this market. Has a small top and excellent form and a small tap root; it is in every way a great improvement over the old variety of Egyptian Beet. It was improved by the late Josiah Crosby of Arlington, Mass. Our stock is selected as to trueness of shape and color.

DETROIT DARK RED-A grand beet for market gardeners; tops exceptionally small and upright, roots are a perfect turnip shape with small top rods. Color of skin dark blood red, flesh bright red. Quality is the very best, sweet, tender and lasting. All through the western country the Detroit has an unequalled reputation. Exposed on the market by the side of other beets it at once catches the eye of the customer and completely dwarfs in appearance all other sorts.

EXTRA EARLY EGYPTIAN-One of the very earliest, with small top; roots distinctly flat and moderately thick, very dark red; flesh dark purplish red, zoned a lighter shade.

BEET SEED FOR BEET GREENLarge topped dark red beet.

\section{MANGEL WURZEL, FOR STOCK FEEDING}

MAMMOTH LONG RED, or NORBITON GIANT-This variety has produced the largest yield of any kind of mangel. The quality of the roots for feeding is high. The roots grow very large and keep well. They are quite long, light red in color and grow well out of the ground so are easily harvested.

\begin{tabular}{|c|c|c|c|}
\hline \multicolumn{4}{|l|}{ BEET } \\
\hline & 1-oz. & 4-oz. & $1-1 b$. \\
\hline Early Wonder.. & $\$ 0.10$ & $\$ 0.20$ & $\$ .75$ \\
\hline Crosby's Egyptian. & .10 & .20 & .75 \\
\hline Detroit Dark Red.. & .10 & .20 & .75 \\
\hline Extra Early Egyptian ... & .10 & .23 & .75 \\
\hline Seed for Beet Greens.. & & .15 & .50 \\
\hline Mangel Long Red. & & .15 & .50 \\
\hline Giant Half Sugar Rose.. & & .15 & .50 \\
\hline Golden Tankard....... & $\ldots$ & .15 & .50 \\
\hline Sludstrup & . & .15 & .50 \\
\hline Swiss Chard & .10 & .20 & .75 \\
\hline Extra Early Sunrise............. & .10 & .20 & .75 \\
\hline
\end{tabular}

GIANT HALF SUGAR ROSE-White with a rosy top. Flesh is pure white, yields enormously; grows half out of ground and is easily harvested.

GOLDEN TANKARD - The tops are comparatively small, with the leaf stalks and veins distinctly tinged with yellow. The neck is small. The roots are large, oval, but with bottom usually of larger diameter than top, light gray above ground, deep orange below. The flesh is yellow, zoned with white.

SLUDSTRUP - This variety is more extensively grown in IIolland by dairymen than any other. Its uniform growth of large, well-shaped beets makes it rich in saccharine. Its record for producing rich milk and sweet butter, has made it the popular beet of that country.

SWISS CHARD, LUCULLUS - This variety will quickly produce plants from which leaves may be cut all summer, as you can cut right down to the ground, and new shoots will soon spring up and make a fast growth. Those plants which are allowed to grow will make large curly leaves, with thick lightcolored mid-ribs, which are delicious when cooked and served like asparafus. 


\section{GARDEN BEANS}

\section{Duarf or Bush---Wax Podded Varieties}

Our strains of Beans are exceptionally fine. They are produced by the best growers in this country, who make a specialty of Beans and Peas. The fields are carefully rogued each year, the best seed is handpicked, so that our stock will be found first-class.

WEBBER WAX-or "Cracker Jack"-One of the earliest and best wax varieties. Pods long, straight flat, stringless and of good quality. A prolific bearer and quite free from rust.

UNRIVALED WAX - There is probably no variety of Wax Bean grown that has a greater all-round value than this one. It has a small plant, is very early, and bears enormous crop of pods about $5 \frac{1}{2} 2$ inches long, somewhat curved, semi-flat, rather slim, but fleshy and of the finest texture and tenderness. The color is a translucent pale yellow, and the flavor and appearance when cooked are all that can be desired.

ROUND POD KIDNEY WAX-A round podded wax bean of the finest flavor you can find. It is fairly early, nearly straight and stringless. Being very prolific it makes an excellent marketing variety and it is very brittle, and very meaty with a clear light yellow skin.

CHALLENGE BLACK WAX-Early; pods tender and stringless; seed black.

DA V IS WAX - Good market gardener variety, long attractive yellow pods, fairly early and productive.

BLACK WAX, PENCIL POD-The best of the dwarf, black-seeded wax varieties. Early and very productive. Pods large, $6 \frac{1}{2}$ to 7 inches long, round, straight and crease-backed; strictly stringless, free from fiber, fleshy and brittle; of highest quality; color very clear yellow. Plant growth exceptionally strong and vigorous.

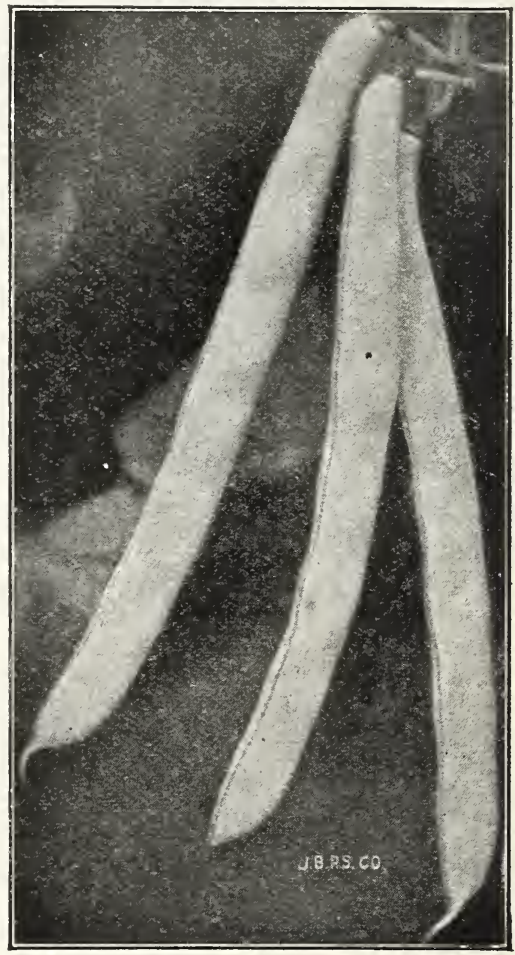

Unrivaled Wax

BEANS, WAX

$1 \mathrm{lb} .15$ lbs. 60 lbs.

Early Wonder Wax $\ldots \ldots . . . \$ 0.25 \quad \$ 3.00 \quad \$ 10.8$

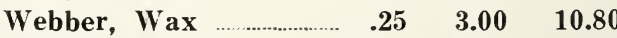

Unrivaled, Wax ……….... $.25 \quad 3.00 \quad 10.80$

Round Pod Kidney, Wax

$3.75 \quad 15.00$

$\begin{array}{llll}\text { Challenge Black Wax } \ldots . . . & .25 & 3.00 & 10.80\end{array}$

Sure Crop Stringless

Wax

$3.00 \quad 10.80$

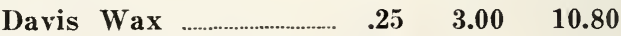

Pencil Pod Black Wax... $.25 \quad 3.00 \quad 10.80$ 


\section{BEANS}

\section{Dwarf or Bush-_-Green Podded Varieties}

GIANT STRINGLESS GREEN POD-Somewhat similar to Burpee's Stringless, but pod is a little longer, straighter and more slender, more depressed between beans and slightly lighter in color; early, hardy and of highest quality. A desirable canner's variety. (Crop Failure)

BOUNTIFUL-Best of the flat-podded stringless varieties. Pods $6 \frac{1}{2}$ to 7 inches long, thick, flat and slightly curved, stringless, slightly fibrous, attractive and of fine quality; color light green. Very early, vigorous, hardy and productive.

REFUGEE, or Thousand to One- A very productive, hardy, vigorous late sort, much in favor with the canning trade. Pods 5 to $5 \frac{1 / 2}{2}$ inches long, somewhat slender, round and slightly curved; almost stringless; fine-grained and good quality; color light green.

FULL MEASURE-A bush variety, popular on account of its wonderful yield and quality. Handsome long green, round pods, of the highest quality and perfectly stringless. It also remains in picking condition many days after maturing, a strong point in its favor, either for market or home garden.

LONGFELLOW-A round, solid, very early, greenpodded bean. Good quality, very tender and crisp, and exceedingly prolific. One of the best for the home garden or market.

HORTICULTURAL DWARF or Cranberry Bush -Late and productive. Broad, flat, loose, stringless pods. The beans are buff splashed with red and are chiefly used for shelling.

\section{FIELD BEANS}

CHOICE NAVY-Our stock of this well known variety has been carefully selected and cleaned and will be found superior to beans commonly offered as "Navy Stock."

BROWN OR SWEDISH - There is a large call for these beans and although we have given them small space, have sold large quantities. It is a fine field variety and the demand is usually good and the price high. The beans are brown in color, medium size and excellent for cooking.

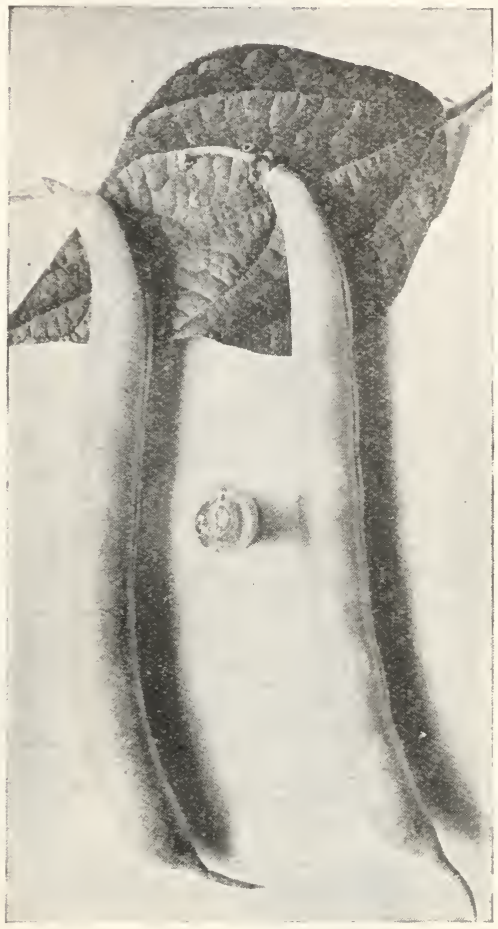

Longfellow

\section{DWARF BUSH LIMA BEANS} FORDHOOK BUSH LIMA-Without doubt the best Dwarf Bush I.ima. Earlier than the Pole Limas by ten days. Pods ineasuring from 4 to 5 inches in length, containing 4 to 5 large beans of excellent quality. The plants grow to a height of 20 to 30 inches; are strong and bushy, and a rich dark green in color.

BURPEE'S BUSH LIMA-New Wonder Strain - This improved strain bears larger crops and is earlier than the old and original variety. The beans are large, flat and of fine quality. This is the earliest large podded Lima, and with us the most prolific of the bush type with large pods.

WOODS EARLY - Is hardy,early and an enormous producer, a grand variety for northern climates. Pods are dark green, medium long, well filled with 3 or 4 large, tender, fleshy beans of excellent quality.

BURPEE'S IMPROVED BUSH LIMABurpee's Improved grows a more vigorous vine than the original Burpee's Bush Lima, with heavier foliage. The single Beans of the Burpee's Improved are also larger, and of even better quality. 


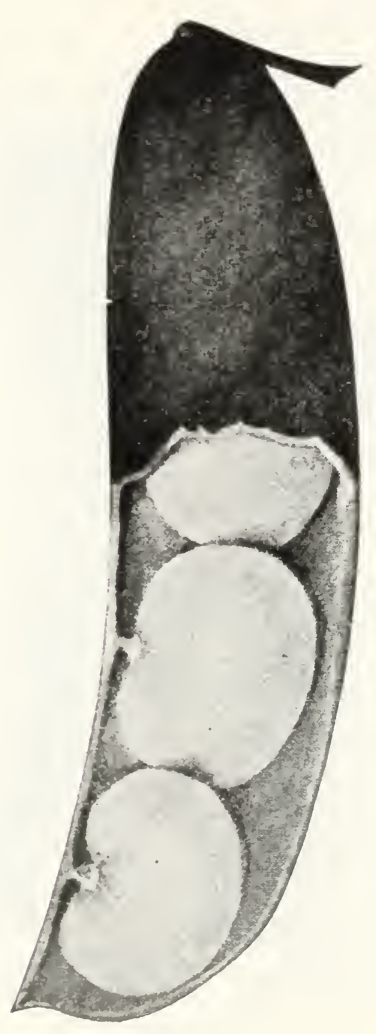

Fordhook Bush Lima

\section{POLE OR RUNNING BEANS}

EARLY LEVIATHAN-A very early, large podded variety, the earliest of the Large Lima class. Pods 5 to 6 inches long, containing 5 to 6 large, flat, white beans.

SCARLET RUNNER-This well-known variety grows about 10 feet high, bearing large sprays of bright scarlet pea-like flowers which are very ornamental. When fully ripened, the Beans are bright scarlet, heavily blotched with purple.

KENTUCKY WONDER - The best early greenpodded Pole Bean for home or market garden. Vigorous and productive; of fine quality.

KENTUCKY WONDER WAX - One of the earliest of the pole wax sorts. Pods 8 to 9 inches long, thick, decidedly crease-backed, very fleshy, brittle, attractive and of fair quality; color light yellow.

\section{BEANS}

ITALIAN GREEN SPOUTING BROCCOLIWe are pleased to announce that we are now able to offer a dependable stock of this very desirable Broccoli, for which there is now a growing demand that will increase rapidly when this splendid vegetable becomes better known.

This variety develops in about 90 days, producing a large head, like cauliflower, consisting of a compact cluster of bluish-green flower heads. When the central head is removed the plant produces many branches, each bearing small heads. These are cut with 3 or 4 inches of the branch attached and tied in bunches for market. The stems as well as the flower heads are cooked and served like cauliflower.

\section{BRUSSELS SPROUTS}

LONG ISLAND-This is by far the most delicately flavored of the cabbage family. Our strain is of half dwarf growth, bearing handsome, solid, round sprouts of best quality crowded together on the stalks.

\section{BEANS, GREEN PODDED}

1. 1b. $15 \mathrm{lbs}$.

\begin{tabular}{|c|c|c|}
\hline Giant St & $\$ 0.25$ & $\$ .300$ \\
\hline Bountiful. & .25 & 3.00 \\
\hline Refugee or $1000-1$. & .25 & 3.00 \\
\hline Full Measure........ & .25 & 3.00 \\
\hline Longfellow. & .25 & 3.00 \\
\hline Horticultural or Cranberry. & .25 & 3.00 \\
\hline White Navy Beans. & .12 & 1.50 \\
\hline Swedish Brown Beans......... & .12 & 1.50 \\
\hline Lima Beans, Fordhook Bush.. & .35 & 4.50 \\
\hline Lima Beans, New Wonder Bush & .35 & 4.50 \\
\hline Lima Beans, Burfee's Improved & .35 & 4.50 \\
\hline \multicolumn{3}{|l|}{ POLE BEANS } \\
\hline Early Leviathan .......... & .35 & 4.50 \\
\hline Scarlet Runner. & .35 & ......... \\
\hline Kentucky Wonder... & .30 & 4.23 \\
\hline Kentucky Wonder Wax....................... & .30 & 4.20 \\
\hline \multicolumn{3}{|c|}{ Italian Green Broccoli, oz. $\$ 1.25,1 / 41 b . \$ 4.00$} \\
\hline Brussels Sprouts........... “ “ $\quad .25$ & “ & .85 \\
\hline
\end{tabular}




\section{HIGH BRED DANISH GROWN GABBAGE SEED}

One ounce of seed will produce 1000 to 2000 plants sown in open ground, or 3000 if sown in frames. It requires 4 to 6 ounces of seed to produce plants for an acre of ground.

METHODS OF CULTURE. To get very early cabbage in the Northern States the seed should be sown in hot beds in February or March, or about six weeks before the ground outside is ready to receive the plants.

\section{NEW EARLY GABBAGE}

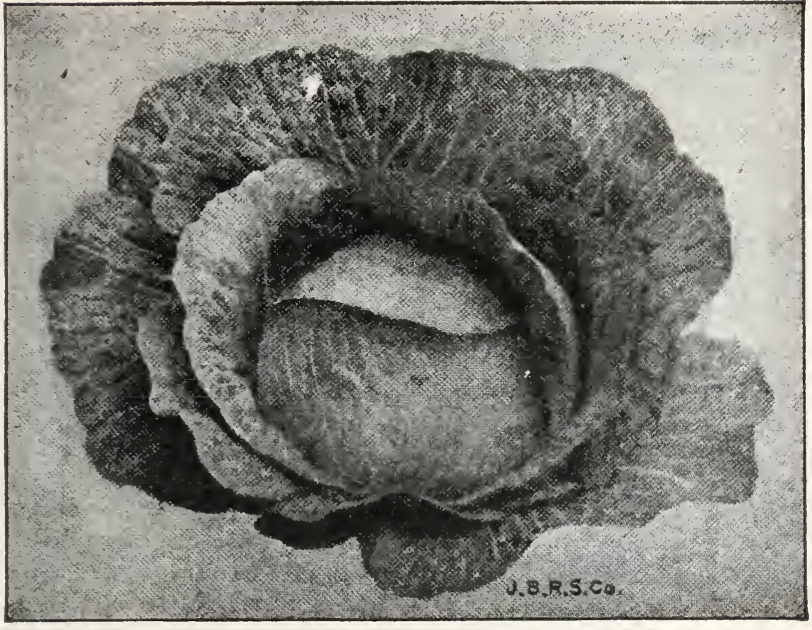

Golden Acre
GOLDEN ACRE-A wonderfully fine early variety with perfectly round heads of good size and which mature a week earlier than Jersey Wakefield. The heads resemble Copenhagen Market of a very finely bred type. Plants are small with but few leaves but the head is of good size, weighing 5 to $6 \mathrm{lbs}$., as round as a ball, very firm and of good bright green color. Every plant produces a good head and they are all just alike.

Owing to its extreme earliness this cabbage will prove profitable for the first early crop. The supply of seed is so limited that we can offer it only in very small quantities this season.
NEW CENTURY - This variety matures between the Copenhagen Market and the Glory of Enkhuizen. It is round headed, gets larger than the Copenhagen and does not erack as easily. It has done splendidly under dry weather conditions, developing perfect heads. We recommend it for both early and late. The heads are very solid and will keep almost as well as those of the Danish Winter Cabbage.

GLORY OF ENKHUISEN-Earlier than the All Seasons; of medium size, globe shaped and handsome dark green color, just right for the market. Leaves fine ribbed; outer leaves set close to permit close planting. Where this variety has been tried in market growing districts the growers have been very enthusiastic.

ALL SEASONS-Heads large, round and very deep; can be planted for early or late crop; a splendid keeper; in season a late second early, coming in with Early Flat Dutch; a favorite with kraut manufacturers
HACO, EARLIEST ROUND RED, (New)-This new sort originated in Denmark, and the seed we offer was grown especially for us by the originator. After extensive field tests we have found it superior to all other varieties of red cabbage in earliness, productivenesss and quality. The color is intense dark red throughout, the heads after being trimmed for market, average 3 lbs. each. If you use Red Cabbage try this one.

BUGNER'S VERY SOLID LATE WINTER (True Strain)-"Yellow Resistant"-This is the best variety of late cabbage we know of. It is very popular around Chicago, Ill., from where this variety originated. It is a type of Holland Short Stem Cabbage, but is entirely distinct. The outer leaves are of a bluish green color. Heads are extra crdinary solid and are splendid keepers. Our stock seed was obtained direct from the originator, Mr. Bugner, a market gardener near Chicago.

MAMMOTH ROCK RED-The largest heading of any red sort. Heads are hard, of deep red color. Quality excellent: 


\section{CABBAGE}

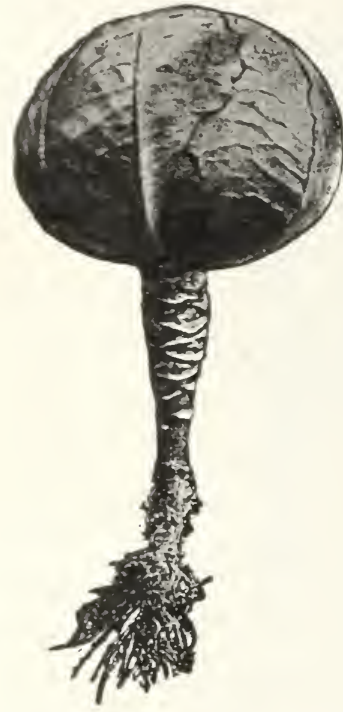

Short Stemmed Holland
SHORT STEMMED HOLLAND - Of late years the gardeners find the short-stemmed Holland cabbage way ahead of the tall stem, with larger heads and give mole tonnage to the acre. This seed is direct from grower of Denmark, so can without doubt, recommend this seed to be first class.

D A N I S H B L L H E A D S H O R T STEMMED-Heaviest yielding strain. Crops of 22 tons per acre are not uncommon -the heads are large, almost perfectly round and very solid, and of good color. Under good average conditions practically every plant produces a solid head. Under general conditions this is probably the most profitable Danish cabbage to raise.

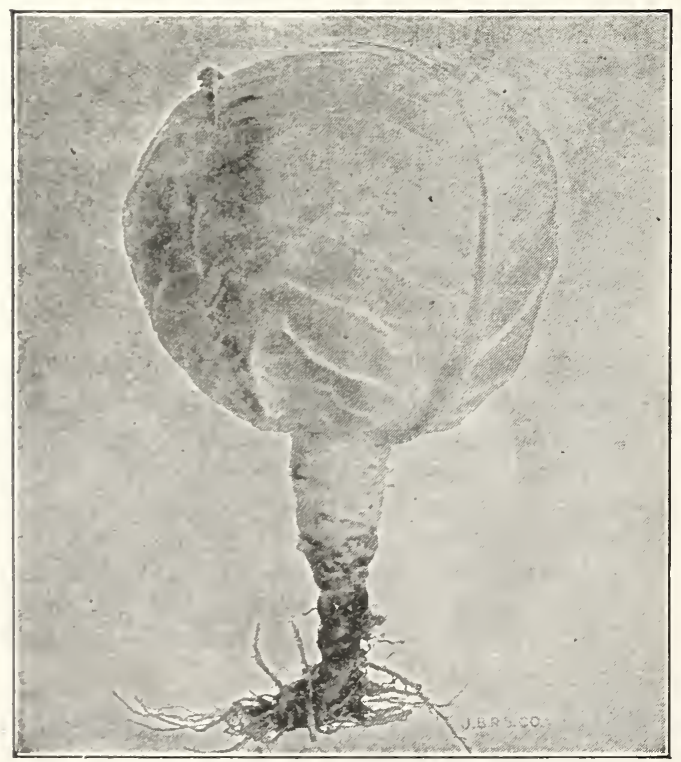

Copenhagen Market
DANISH BALLHEAD, INTERMEDIATE-This strain is much like the Short Stemmed except that the stems grow a little longer and the heads are harder and of deeper green color and, therefore, come out of storage looking better. There is very little difference in the yield of these two strains and where the cabbage is to be stored until spring we would recommend the Intermediate rather than the Short Stemmed Strain.

WISCONSIN No. 8-A "yellows" resistant strain of cabbage developed out of our stock of Hollander under the direction of Dr. L. R. Jones of the University of Wisconsin.

PREMIUM LATE FLAT DUTCH-One of the most popular late sorts where a large head is desired. Heads are large, oval shaped, solid and of splendid quality which will keep for a long time in good condition.

SAVOY PERFECTION DRUMHEAD - This is the hardest heading, most satisfactory, and best allround Savoy Cabbage.

NEW STRAIN OF COPENHAGEN MARKETThis is an extra early strain that is heading up all at once, different from the old strain that used to head up all summer. This is the earliest large round headed cabbage offered today, this is the first year that we have been able to supply this variety of real improved Copenhagen Market.

\begin{tabular}{|c|c|c|c|}
\hline Golden Acre & $\begin{array}{l}\text { E } \\
\text { oz. } \\
0.30\end{array}$ & $\begin{array}{l}4.0 z . \\
\$ 1.15\end{array}$ & $\begin{array}{l}1-1 \mathrm{~b} . \\
\$ 4.00\end{array}$ \\
\hline \multicolumn{4}{|c|}{ New Strain Copenhagen } \\
\hline Market ......................................... & .25 & .95 & 3.50 \\
\hline New Ce & .25 & .95 & $\begin{array}{l}0 \\
0\end{array}$ \\
\hline Season ……........................ & .20 & .60 & 2.00 \\
\hline ly Round Red.. & .40 & 1.35 & \\
\hline Red.... & .2 & .85 & 0 \\
\hline Short Stemmed Holland... & .25 & .8 & 3.00 \\
\hline \multicolumn{4}{|l|}{ Danish Ball Head Short } \\
\hline \multirow{2}{*}{\multicolumn{4}{|c|}{$\begin{array}{l}\text { Danish Ball Head Inter- } \\
\text { mediate }\end{array}$}} \\
\hline & .25 & .85 & \\
\hline \multicolumn{4}{|l|}{$\begin{array}{l}\text { Bugners } \\
\text { Wisconsin No. } 8\end{array}$} \\
\hline Wisconsin No. 8 .. & .45 & 1.60 & 6.00 \\
\hline \multicolumn{4}{|l|}{ Premium Late Flat } \\
\hline \multicolumn{4}{|c|}{ 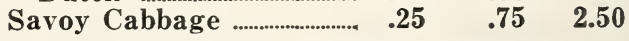 } \\
\hline OR CEI & & $\triangle \mathrm{PR}$ & \\
\hline Pe Tsai & .25 & .7 & \\
\hline Wong Bok & & & \\
\hline
\end{tabular}




\section{LINDHOLM'S FINE STRAIN OF GAULIFLOWER}

Cauliflowers delight in a rich, moist soil, and in dry seasons should be abundantly watered, especially when heading. Sow the seed in the hotbed in January or February and transplant the plants 2 or 3 inches apart in another hotbed, until such time as they are safe to be planted in the open ground. If properly hardened off, they are seldom injured by being out too early. When heading tie the outside leaves loosely over the head to protect it from the sun.

One ounce produces from 1,500 to 2,000 plants.

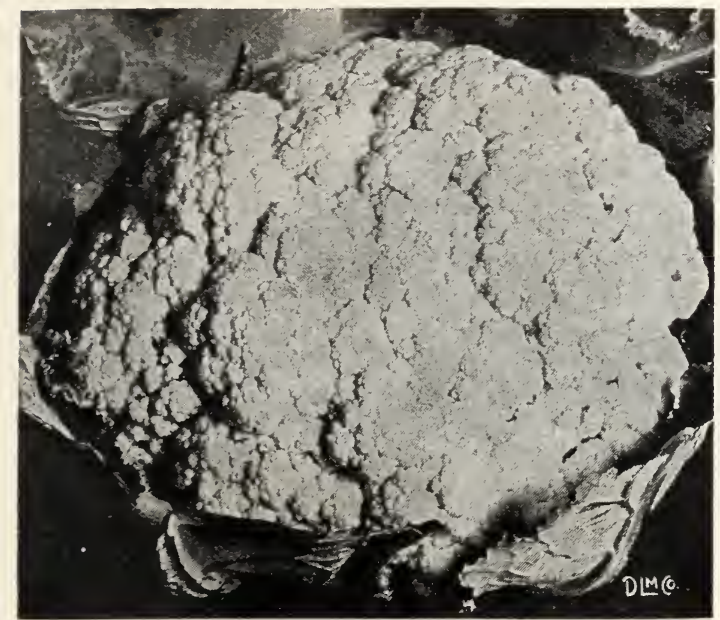

Henderson Early Snowball

EXTRA EARLY COPENHAGEN SNOWBALL - The very best cauliflower for early planting, with a trifle smaller leaves than Henderson's Snowball, but one of the surest headers we have ever tried.

HENDERSON'S EARLY SNOWBALL-One of the most popular sorts for growing outside. Heads good size and compact. Our strain of this important variety is unsurpassed.

DANISH GIANT (Dry Weather)-The growth is very similar to that of Early Dwarf Erfurt, but with heavier foliage, and is less liable to blight in hot weather. It has been grown with excellent results where other varieties fail to form heads, especially in locations subjected to long droughts.

AUTUMN GIANT - The best large late Cauliflower especially desirable for mixed pickles.

\section{CHOICE CELERY SEED}

G O L D E N S E L F . BLA NCHING -This grand Celery is of French origin. It has the de$\mathrm{m}$ a $\mathrm{nd}$ above all other sorts because of its many superb qualities. It has the same self blanching habit as White Plume, but it is much heavier and more c $0 \mathrm{~m} \mathrm{p}$ a c $\mathrm{t}$, though not so early. Grows to good size, is very tender and free from strings, the heart large and solid, crisp, brittle, of excellent quality and very beautiful.

WHITE PLUME (Perfected)-A very superior stock. Does not require to be earthed up, but if only loosely tied and soil drawn close around the base of the leaves to keep them close together, all the inner leaves and stalks will turn white and crisp.

\section{CELERIAC, OR TURNIP- ROOTED CELERY}

LARGE SMOOTH PRAGUE-(Extra Select)In our Extra Select Stock we claim to have the finest strain of Root Celery it is possible to produce. The bulbs are globe-shaped, large, smooth, and are entirely free from side roots.

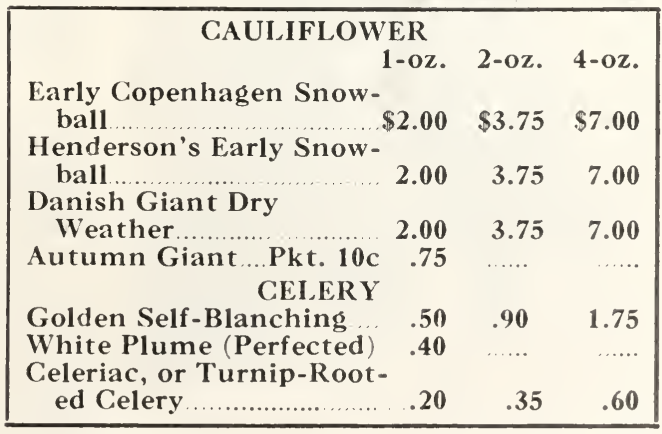




\section{CHOICE GARDEN GARROTS}

Carrots are not alone one of the most wholesome of foods, supplying precious vitamines, but when half-grown are one of the greatest delicacies possible to place on the table. Persons who say they do not like carrots usually will be found never to have tried them young. The seeds are very slow to germinate and they should be marked in the row with radishes or some other quickly-maturing crop which will be harvested before the carrots crowd. Mellow soil which will not bake over the seeds and will not harden in midsummer is the kind carrots like. Plant in rows 20 to 24 inches apart. Carrots do best on peet ground.

EARLY CHANTENAY-The best bunching carrot. This is the best early carrot in existence, one which market gardeners should plant for their main early crop. The carrots grow about six inches long, are stump rooted, very smooth, deep red, fine grained, sweet and sugary, and not apt to crack open while growing. An excellent table sort and a heavy cropper. Our seed is most carefully selected.

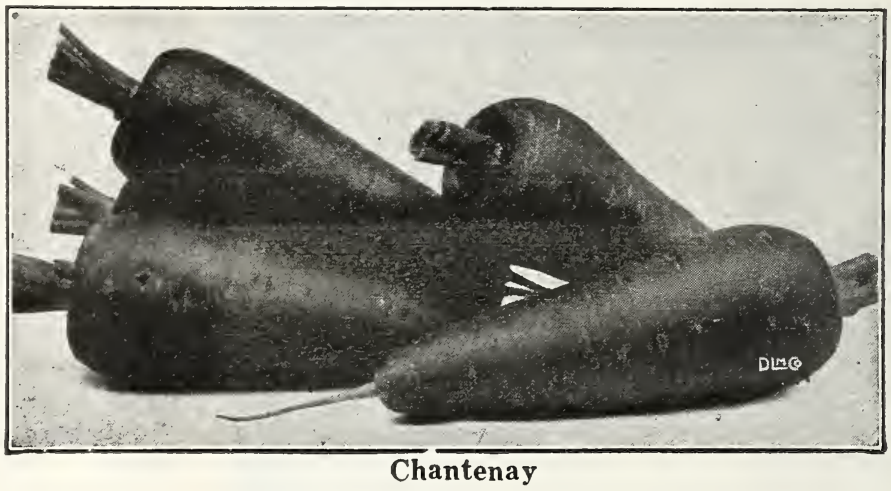

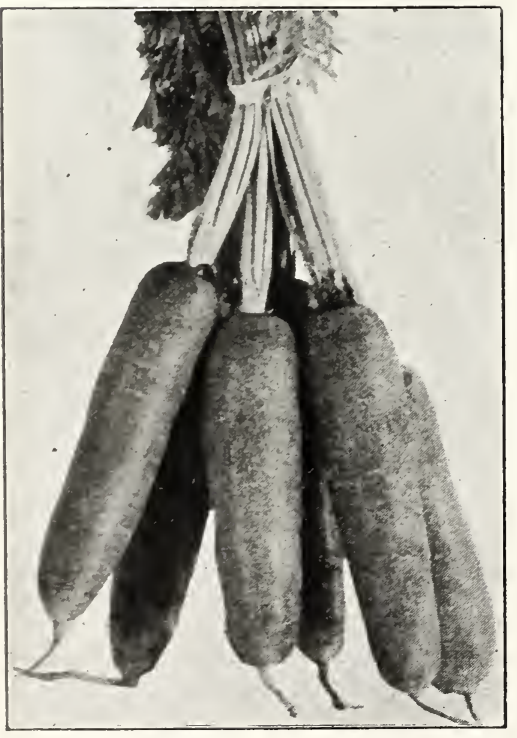

Select Danvers Half Long

\section{A NEW CARROT}

BAGLEY - A large and very productive carrot of fine quality. It has a beautiful red orange color, shows no green around the top of the root, and grows a medium size top. Where the bushel box is used for marketing they will pack very handsomely, as two roots just about cross the box. Should be planted on low ground only.

SELECT DANVERS HALF LONG-This is a big improvement over the ordinary Danvers half long. Is a well known stump rooted variety. The root is of a rich dark orange color, smooth and heavy yielding, making it very desirable for both marketing and stock feeding. Roots will grow to 7 or $7 \frac{1 / 2}{2}$ inches in length. This is an excellent bushel carrot and one of the most popular of American varieties. Grows a little longer and larger than Danvers. 


\section{GARROTS}

SUNRISE CARROT-This is a new carrot crossed between the Chantenay and the Danvers half long, with the length of Danvers and almost the shape of Chantenay. The Market Gardeners have been looking for sometime for a carrot that will grow a little longer than the Chantenay especially on the low ground. I think this is the carrot they have been looking for, but it will be a week or ten days later than the Chantenay, but it will be a fine late bunching carrot. It is a blunt point. The color is a rich, deep orange, the table quality excellent, and its yield greater per acre than any other.

IMPROVED LONG ORANGE-An excellent intermediate season, standard sort; roots 12 inches long, about 3 inches broad at the crown, tapering regularly to a point; deep orange color.

OXHEART, OR GUERANDE-Mature roots $41 \frac{1}{2}$ to 5 inches long, very stout and thick, ending in an abrupt, small tap root; small top and easily harvested; color light bright orange.

NANTES CORELESS-For extra sweetness, this is all by itself. It is of good shape and size. The leaves are fine and the roots almost cylinderical,very smooth and grow about six inches long; the flesh is entirely red and very sweet and almost entirely without a core.

\section{STOCK CARROT}

VICTORIA - The largest and unquestionably the heaviest cropping yellow carrot in cultivation. The roots are remarkably fine, very symmetrical, and of excellent quality, possessing high feeding properties. It is especially adapted for rich land, although a heavy cropper on all soils. It is easily harvested, as the roots grow largely above the ground.

MASTODON, OR WHITE VOSGES-A large white carrot for stock. The roots grow very large, but being thick and not too long, they can be easily pulled. We think this variety will yield more good, nutritious carrots per acre than any other variety.

\section{CRESS}

TRUE WATER-This is a distinct variety of cress with small, oval leaves. It thrives best when its roots and stems are submerged in water although a fair growth may be obtained in soil which is kept wet. It is one of the most delicious of small salad plants and should be planted wherever a suitable place can be found. The seed is usually sown and lightly covered in gravelly, mucky lands along the borders of small, rapid streams. The plants will need no subsequent culture, as under favorable conditions they increase very rapidly by self-sown seed and root extension.

BORAGE - A hardy annual used as a pot herb and for bee pasturage. The bruised leaves immersed in water give it an agreeable flavor and are sometimes used in salads to give a cucumber-like taste.

\begin{tabular}{|c|c|c|c|}
\hline \multicolumn{4}{|c|}{ CARROTS } \\
\hline Early Chantenay & $\begin{array}{c}1 \text {-oz. } \\
\$ 0.10\end{array}$ & $\begin{array}{r}4-o z . \\
\$ 0.20\end{array}$ & $\begin{array}{r}1-\mathrm{lb} . \\
\$ 0.75\end{array}$ \\
\hline Improved Long Orange $\ldots$ & .10 & .20 & .75 \\
\hline Oxheart, or Guerande & .10 & .20 & .75 \\
\hline Nantes Coreless ..................... &. .15 & .35 & 1.25 \\
\hline Bagley ..... & .15 & .40 & 1.50 \\
\hline Sunrise & .10 & .20 & .75 \\
\hline Select Danver's half long & .10 & .20 & .75 \\
\hline \multicolumn{4}{|c|}{ STOCK CARROT } \\
\hline Victoria & .10 & .25 & .75 \\
\hline Mastodon, or White & & & \\
\hline Vosges & $\begin{array}{r}.10 \\
1-\mathrm{oz} .\end{array}$ & $1 / 4-25$ & .75 \\
\hline CRESS, True Water......... & .25 & .90 & $\ldots$ \\
\hline BORAGE & .10 & .35 & $\ldots . . . .$. \\
\hline
\end{tabular}




\title{
LINDHOLM'S SELEGT GUGUMBER SEEDS
}

\author{
New Cucumber
}

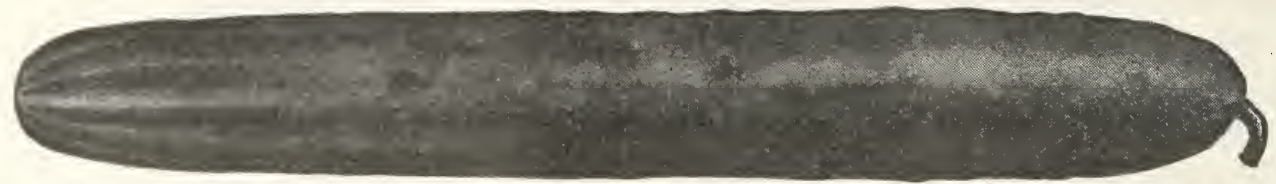

Ideal Market

LINDHOLM'S IDEAL MARKET - We have for many years searched for a long cucumber suitable for indoor or outdoor culture and believe we have at last found in it this new variety. Lindholm's Ideal Market is more uniform in shape and size, thinner and more prolific than any of the long white spine sorts. We consider this variety the acme of perfection for the market gardener and amateur alike. Sure to please. Since we introduced Ideal Market the demand has been so great and the call so persistent for seed of this strain of Cucumber, at a price that will allow it to be grown as a general out-of-door crop, that we grew several acres last summer from the Original Greenhouse Grown Selected Seed. Field grown Ideal Market Cucumbers are as perfect as those grown under glass. They have the size, shape, color and quality of the perfect cucumber and are money-makers for the grower. The cost of the seed puts it within the reach of every grower.

LINDHOLM'S NEW PERFECTION-A wonderful choice variety, which, though developed and selected for years for greenhouse culture, has, on a large scale, proved remarkably successful outdoors. Under good culture and favorable conditions this variety will give a crop that will compare favorably with the best indoor Cucumber as to size, color and finish. It will average 12 inches in length, is a beautiful dark green, almost spineless, and will keep its color under the leaves for several days. It is admirably adapted for packing in flats, in the same way as the greenhouse crop is shipped for the highest class trade.

\section{EX'TRA LONG or EVERGREEN WHITE SPINE} - A very fine strain of the White spine type; is longer than the ordinary White Spine and holds its rich dark green color well down to the blossom end; immense cropper. A choice variety for hot-house growers; also hard to excel for outdoor cultivation.
IMPROVED LONG GREEN-Is a strain improved and developed by re-selection. The vines of our strain are very vigorous, and productive; the fruit (12 to 15 inches long) is formed almost as easily as the short sorts. As a cucumber of the "black spine" variety, for slicing and for pickles, this is one of the very best. The flesh is very firm and crisp and has a distinctive fine flavor, quite its own; they make excellent pickles, and when yellow and ripe the best sweet pickles. The fine dark green color, the size, shape, crispness, and flavor, make this the best of the "black spine" varieties.

DAVIS PERFECTION-By using this variety gardeners can produce out-of-doors cucumbers that will sell in the market for hothouse forcing varieties. The shape is ideal. It is almost seedless one-third of its length from the stem, and the few seeds that are contained in its blossom end when in eating condition are so small and tender that they are hardly noticeable. Most important of all, it does not lose its dark, rich color when grown out doors. It is hard to tell the difference between it and a hothouse cucumber.

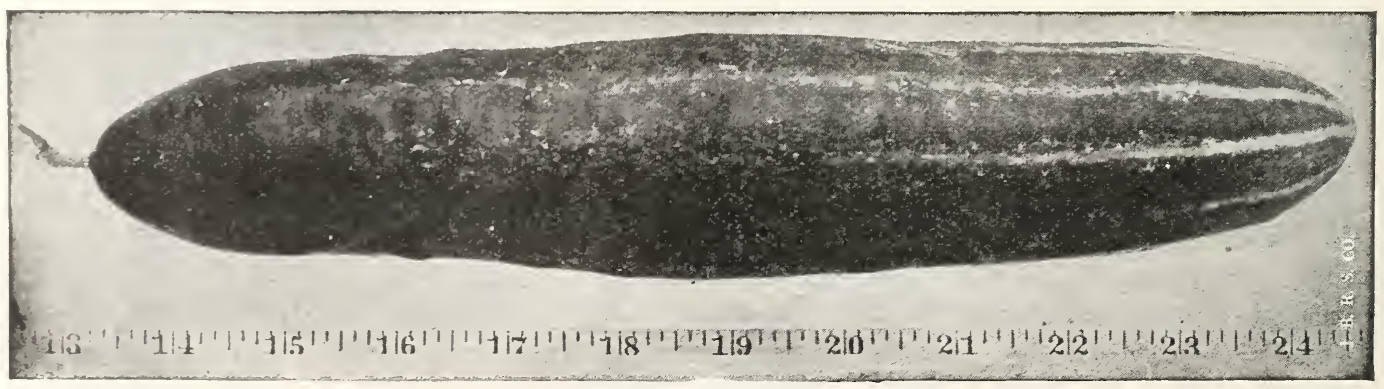

DAVIS PERFECT 


\section{LINDHOLM'S SELECT CUCUMBER SEEDS}

SELECT EXTRA EARLY WHITE SPINE-A selection of the Improved White Spine, but earlier, more perfect in shape and more prolific. The best slicing variety we have seen, being solid in flesh, fine-grained, tender and of delicious flavor. Vigorous, healthy grower. A splendid sort for the home garden, and absolutely without an equal for market.
EARLIEST OF ALL-An extra early, prolific, desirable White Spine much in favor in the south for early shipment to northern markets. Fruit very full and uniform, tapering slightly but abruptly at both ends; color a good deep green. A week to ten days earlier than Early Fortune.

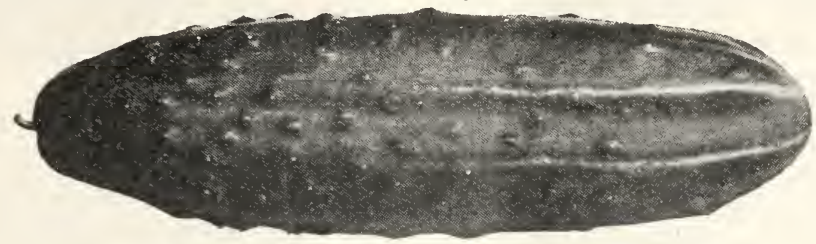

Early Fortune

EARLY FORTUNE CUCUMBER - Is the earliest and best cucumber for table, market or shipping purposes. Having a rich dark green color, retaining its color a longer period than any other variety.: it!is a longer cucumber than any of the White Spine varieties. Ripe in 55 days.

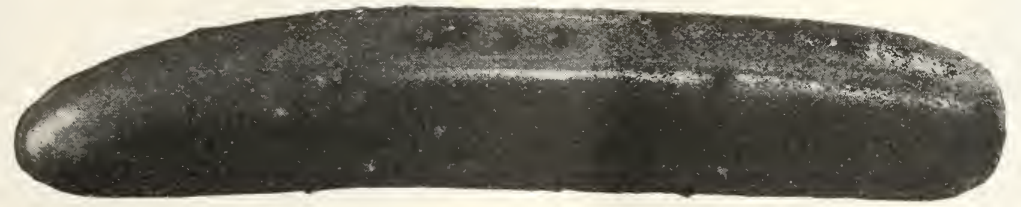

Woodruff's Forcing

WOODRUFF'S HOT-HOUSE PERFECTION-A surprising new cucumber, obtained from the crossing between Davis Perfection and a long English forcing. The introducer claims this cucumber to be 12 to 15 inches in length. The color being dark green with the shape of White Spine. This seed is?out-door grown, which brings the price down for gardeners' general use.

NEW PICKLING CUCUMBER-Picklers Early Perfection is a new cucumber, being the very earliest grown, having the same shape and color as the White Spine, only smaller in size. With early planting the gardeners will find this to bring more money for

\begin{tabular}{|c|c|c|}
\hline \multicolumn{3}{|l|}{ CUCUMBERS } \\
\hline 1-oz. & 4-oz. & $1-1 b$ \\
\hline Lindholm's Ideal Market $\$ 0.20$ & $\$ 0.60$ & $\$ 2.00$ \\
\hline " New Perfection & .60 & 2.00 \\
\hline Extra Long Evergreen & & \\
\hline White Spine $\ldots \ldots \ldots \ldots \ldots$ & .35 & 1.25 \\
\hline Woodruff's Hothouse Per- & 45 & 1.50 \\
\hline Improved Long Green & .45 & $\begin{array}{l}1.50 \\
1.25\end{array}$ \\
\hline Davis Perfection ............. & .35 & 1.25 \\
\hline Select Early White Spine. & .30 & 1.00 \\
\hline Early Fortune & .35 & 1.25 \\
\hline Earliest of All.. & .30 & 1.00 \\
\hline New Pickling. & .30 & 1.00 \\
\hline Chicago Pickling & .25 & .90 \\
\hline Snow's Fancy Pickling & .30 & 1.00 \\
\hline Sunrise................................. .20 & .60 & 2.00 \\
\hline
\end{tabular}

early slicing than any other, as it can be used until the White Spine is ready and still have the finest cucumber to be had for pickling.

CHICAGO PICKLING - An early maturing, very small, dark green cucumber; cylindrical, square ended, and very popular with many growers who want an ideal bottle pickle. The seed we offer was grown from a very fine lot of stock seed, procured from the originator.

SNOW'S FANCY PICKLING - This is a selection made from the "Chicago Pickle" by a veteran pickle grower in the West. The type is shorter when ripe than the Chicago Pickle and is broad at the stem end, tapering slightly to the tip. The small pickles are dark green, cyclindrical and square ended. We offer a strain of most carefully selected seed. Ready for market in about 50 days.

SUNRISE-A very fine long, slender, dark green cucumber of high quality. The fruit is 10 to 12 inches long and only 2 to $2 \frac{1}{2}$ inches in diameter, very deep green and holds its color a long time after picking.

We have never seen finer cucumbers growing in the open ground. They are equal to the hothouse products. The vines are vigorous and productive. Gardeners will find this new variety one of the very best for home use or market. 


\section{NORTHERN GROWN SWEET GORN}

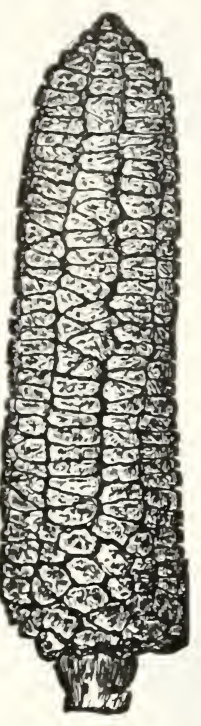

Early Dow

\section{Sweet Corn---It is Air Dried---It is Tested}

DOW'S EXTRA EARLY - This is an improvement of the Extra Early Cory Corn that has been selected for a number of years by Geo. Dow, one of the best market gardeners, as being the finest of all Sweet Corn for table use. The cobs being better set and rarely produce less than two well developed ears to a stock, and generally more. The largest improvement being it is earlier than any corn put in the Minneapolis market. The stocks are very short. The market gardeners would do best by using this corn altogether for early marketing.

CROP FAILURE

When ordering Sweet Corn do not forget the Early Gem and Ex Early Sunrise, also the Golden Cory, the 3 best Early Sweet Corn on this market.

\section{Mustard}

SOUTHERN GIANT CURLED-Plant vigorous and hardy, of upright, spreading growth; leaves 5 inches long by 3 inches wide, light green, tinged yellow, much crumpled and frilled at the edges. The popular market variety in the South; seed small, dark reddishbrown.

\section{Collards}

TRUE SOUTHERN-A plant of the cabbage family. It is well adapted to the South, enduring extreme heat; excellent for greens.

\section{Kale or Borecole}

DWARF GREEN CURLED OR SCOTCHVery dwarf and spreading. The leaves are beautifully curled and of a bright green color. Hardy.

EARLY SUNRISE SWEET CORN. We regard this as the most important new variety introduced in years. With this new strain it can be had a WEEK TO TEN DAYS EARLIER than ordinary strains of Bantam.

Think what this means to the Market Gardener and those who sell corn at the roadside stand. They who are fortunate enough to have this new early corn will be able to sell it quickly and at much better prices than others who have only the three early white varieties.

The ears are like Golden Bantam in all respects. They have 8 to 10 rows of medium size yellow kernels. The stalks are about five feet tall.

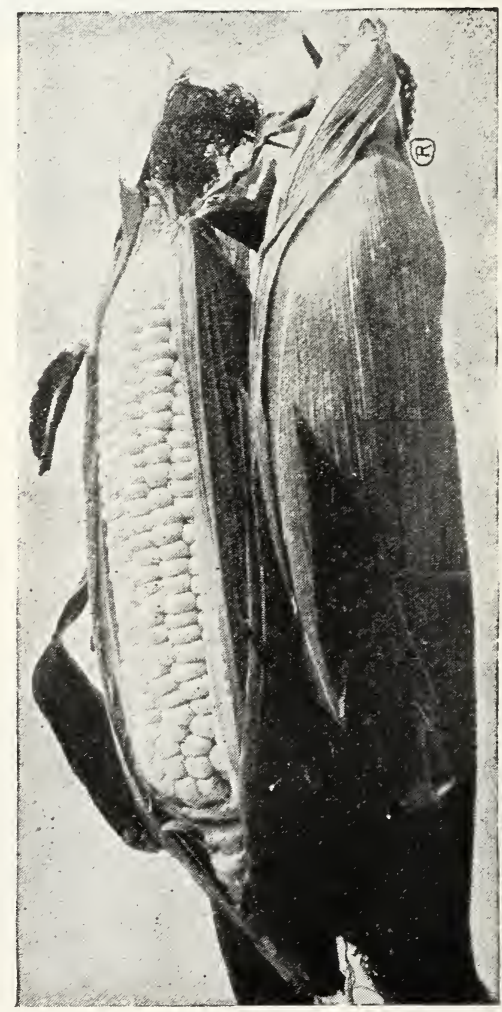

Early Sunrise 


\section{SWEET CORN}

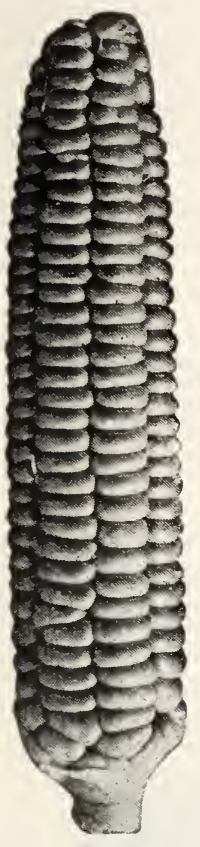

Golden

Bantam
LINDHOLM'S SELECT EXTRA EARLY GOLDEN BANTAM - Twice as many ears of the same famous flavor. Since the introduction of the Golden Bantam Sweet Corn many new and supposedly superior varieties have been introduced. We have tested a number of them and have yet to find one its equal in sweetness. The only objection to Golden Bantam has been its tendency to produce a few small ears. This fault we have overcome by years of selection, saving our seed from the largest and most perfectly formed ears and the strongest and most productive plants. In this way we have worked up a strain of Golden Bantam with two and three large ears to the stalk and retained the same sweet, juicy flavor that has made Golden Bantam the most sought for corn on the market.

This corn is earlier than the common Golden Bantam.

\section{SWEET CORN}

\begin{tabular}{|c|c|c|c|}
\hline Extra Early Dow................... & $\begin{array}{l}1-1 b . \\
\$ 0.30\end{array}$ & $\begin{array}{c}12-1 b s .4 \\
\$ 2.50\end{array}$ & $\begin{array}{r}8-1 b s . \\
\$ 9.00\end{array}$ \\
\hline Stowell's Evergreen. & .25 & 2.25 & 8.00 \\
\hline Whipple's Yellow................ & .25 & 2.50 & 9.00 \\
\hline \multicolumn{4}{|l|}{ Select Extra Early Golden } \\
\hline 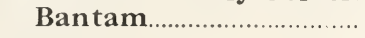 & .25 & 2.50 & 9.00 \\
\hline Golden Leader.................. & .25 & 2.25 & 8.00 \\
\hline Golden Giant... & .25 & 2.25 & 8.00 \\
\hline Bantam Evergreen... & .25 & 2.50 & 9.00 \\
\hline Golden Cory............... & .25 & 2.50 & 9.00 \\
\hline Sunshine...$\ldots \ldots \ldots \ldots \ldots \ldots$ & .25 & 2.50 & 9.00 \\
\hline Sunrise.. & .25 & 2.50 & 9.00 \\
\hline Common Golden Bantam & .25 & 2.00 & 7.00 \\
\hline Mustard ............................... & .10 & .30 & 1.00 \\
\hline Collards ............................ & .10 & .30 & 1.00 \\
\hline Kale or Barceole................... & .10 & .30 & 1.00 \\
\hline
\end{tabular}

GOLDEN BANTAM-This is becoming more popular each year as people begin to appreciate the wonderful flavor and sweetness of the yellow varieties of sweet corn. No market or home garden can afford to be without at least two plantings of this wonderful corn during the season.

WHIPPLE'S YELLOW-A new yellow Sweet Corn that matures two weeks later than Golden Bantam and in addition grows ears 7 to 8 inches long and 12- to 16-rowed, with often two ears to one stalk. Whipple's Yellow grows quite tall and the quality of the Corn is excellent. This will take the place of Bantam Evergreen.

\section{LINDHOLM'S GOLDEN LEADER SWEET CORN-} This corn is a cross between the Golden Bantam and Quincy Market, having the flavor of Golden Bantam and the shape and size of Quincy Market but larger, growing from 12 to 16 rows. There is no corn in the market that can compete with this.

GOLDEN GIANT-A little later than Golden Bantam, but is larger and of good quality. Color light yellow

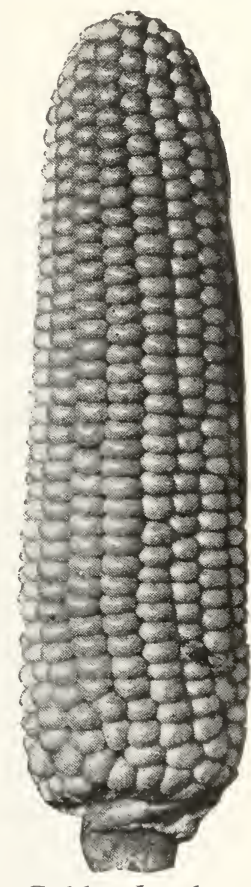

Golden Leader

BANTAM EVERGREEN-When once you have tasted a yellow grained Sweet Corn no other will ever again satisfy you. Bantam Evergreen has the good qualities of the Early Bantam but is a much heavier yielder. Ears eight to ten inches long with twelve rows of delicious and tender yellow grains.

EARLY SUNSHINE-A wonderful new extra early North Dakota, by Prof. Yaeger of the N. D. Agricultural, a cross between Golden Bantam and an English variety, ears are larger than Golden Bantam, 12 rowed, ready for use 6 to 10 days earlier than Bantam. 


\section{SWEET CORN}

GOLDEN CORY-This corn is crossed between the Mammoth Cory and the Extra Early Golden Bantam. It is just as early as the Early Sunrise but it has a good deal larger ears. They have 10 to 12 rows. This new variety has a beautiful golden color, fine flavor and it is a big yielder with two ears to nearly every stock. Market gardeners around Minneapolis and St. Paul make more money on the Golden Cory and the Early Sunrise than all the other kinds of sweet corn put together.

\section{CHINESE or CELERY CABBAGE}

PE TSAI-Produces a long top or head 12 to 15 inches long, which blanches to a beautiful clear white. Sow in hot beds for early or treat as late cabbage for winter use. This was originally imported from China. It resembles in growth Romaine or Cos Lettuce.

WONG BOK-The heads of this sort are shorter and average heavier than other varieties. Wong Bok has beautifully curled leaves of fine quality and is a sure header.

\section{EGG PLANT}

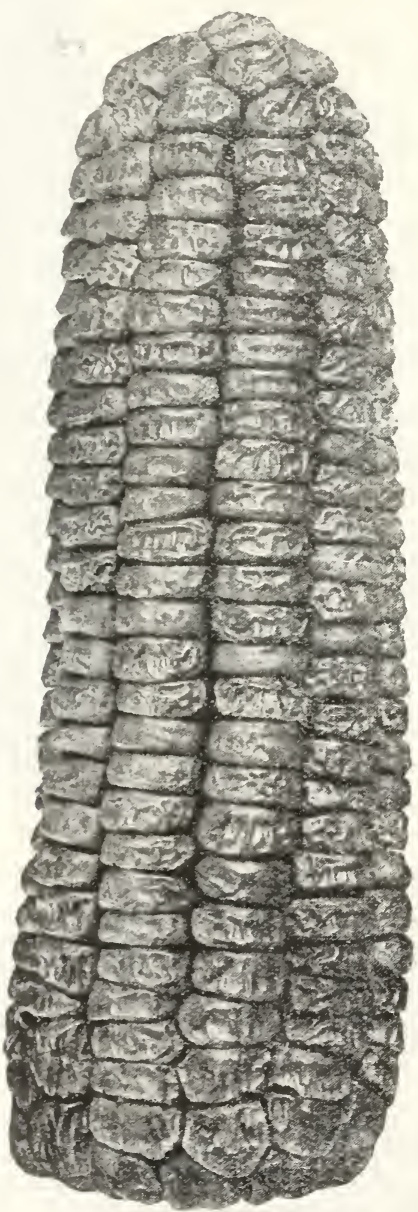

NEW YORK IMPROVED LARGE PURPLE: This variety is largely grown and produces the Eggplants in great quantities, as the plants bear from six to eight fruits each. They are large, nearly round, dark purple, free of thorns and of excellent quality.

\section{BLACK BEAUTY}

- Is ten days to two weeks earlier than New York Improved The fruits are large, of a rich, glossy purplish black color, very handsome and attractive -It is entirely free from spines.

ENDIVE, MOSS GURLED - One of the best autumn, winter or spring salads. Plants form large, dense clusters

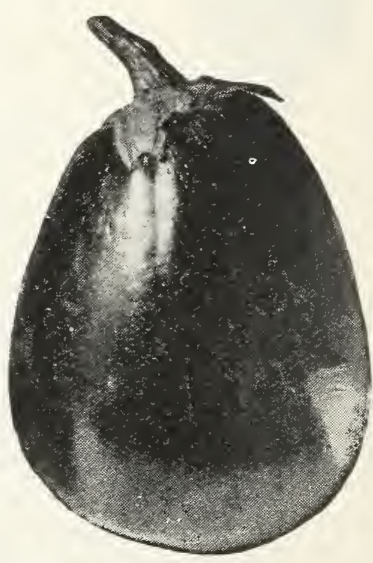

Black Beauty of finely divided, green leaves, which when properly blanched, are exceedingly crisp and tender.

\section{CHINESE OR CELERY CABBAGE}

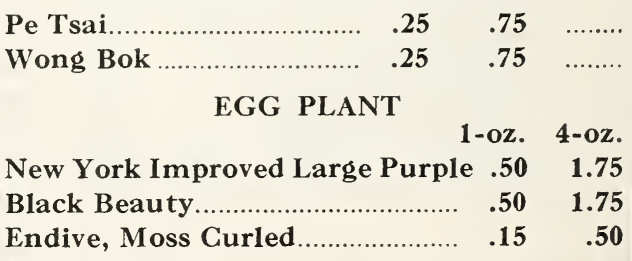




\section{LINDHOLM'S SUPERIOR LETTUCE SEED}

SELECTED GRAND RAPIDS --Especially adapted for greenhouse culture in Winter; also a good Lettuce to sow outside early in the Spring for family use.

Grand Rapids does not form a head, but makes large, compact bunches of light, attractively curled and fringed leaves. It grows very rapidly and keeps in good marketable condition for a long time after cutting. We take special pains to have our strain of Grand Rapids very true to type and are selling some of the largest greenhouse_Lettuce growers their supply annually.

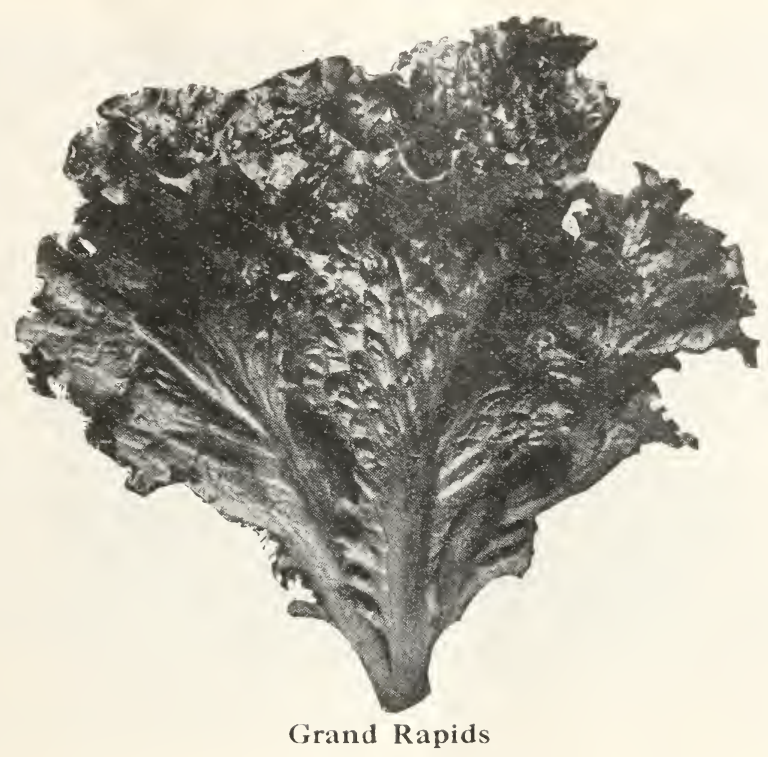

BLACK SEEDED SIMPSON-Forms a large bunch of curled, crisp and very tender leaves which are of excellent quality. One of the best of the large loose-leaved varieties.

BIG BOSTON-Very popular for outside culture as well as cold frame forcing. Head large and compact; leaves broad, almost smooth, but wavy at the edge; color light green, slightly tinged reddishbrown; heart greenish-white, tinged yellow; of fair quality.

PRIZE HEAD - Mammoth heads; even the outer leaves are crisp and tender; light green, tinged with brownish red; superb flavor; very hardy; very fine for home use; too tender to ship any great distance.

MAY KING-A large, light green, very early heading sort, which does exceedingly well either for an early outdoor crop or for forcing under glass.
SALAMANDER - For a Summer variety this is one of the best; good-sized heads, and stands drought and heat with little injury.

NEW YORK OR WONDERFUL-A good summer Head Lettuce, one of the slowest to run to seed; of excellent flavor; very crisp and tender, heads of immense size and very solid, so solid, in fact, that when seed is wanted the heads must be slashed to permit the seed stalk to come through.

ICEBERG-One of the best varieties. Heads early and stands without running to seed a long time. The leaves are finely cut and curled, and of an attractive light green, while the center of the head is pure white and remarkably crisp and of fine quality. It is certainly one of the best kinds. We have a very fine strain that heads uniformly solid and compact. 


\section{LINDHOLM'S HOT WEATHER LETTUCE}

We have found this to be absolutely the best firm heading lettuce to grow through the summer months. It will not scald or burn and will make a head when other varieties fail. This variety of head lettuce has continually grown in the favor of both private and market gardeners and is the most reliable hard-heading lettuce ever introduced, far superior to all other varieties of cabbage-lettuce. It is adapted to both spring and suinmer use, as it withstands intense heat and forms magnificent large heads with leaves closely set, extremely solid heart, even before it is half grown. The color is a beautiful yellowish-green and the flavor is excellent, being rich and buttery.

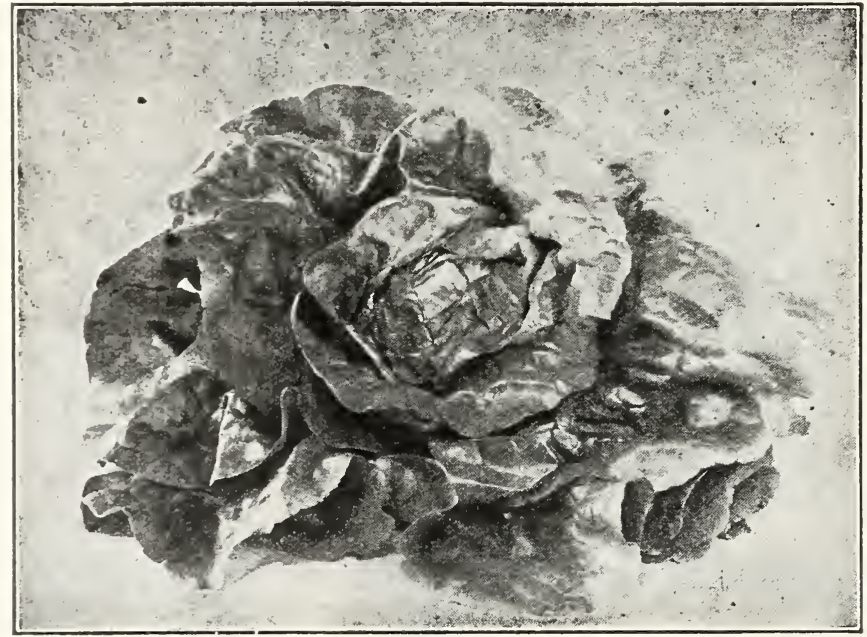

MIGNONETTE - A small early, crisp and curled cabbage heading variety; plant very compact, forming a hard, globular, well balanced head; leaves broad, excessively blistered, crumpled and twisted; color medium dark brown with a dark greenish tinge; quality good; recommended as one of the very earliest heading varieties.

\section{CHICKEN LETTUCE}

CHICKEN LETTUCE-Your poultry needs 'green' food and this variety of Lettuce is just the thing you will want to grow for this purpose. It is a genuine Lettuce which will yield as much or more chicken or rabbit feed as any plant that you may have used for 'greens.' When once cut it starts to grow again and makes a successive crop.

\section{LINDHOLM'S BEST MIXED LAWN GRASS SEED}

\section{LINDHOLM'S BEST MIXED LAWN GRASS}

SEED-Our preparation of Lawn Grass Contains Blue Grass, White Clover and Sweet Vernal Grass and other very choice and fine varieties, and is, we think, the very best preparation possible for our hot and dry summers, as we have been long making experiments to ascertain this fact.

Lindholm's mixture of Lawn Grass Seed is unsurpassed either for lawns, parks or grass plats. It forms a thick, compact growth of short-growing varieties, following one another in succession, and can be highly recommended.

\begin{tabular}{|c|c|c|c|}
\hline \multicolumn{4}{|c|}{ LETTUCE } \\
\hline Grand Rapids. & $\begin{array}{l}1-0 z . \\
\$ 0.15\end{array}$ & $\begin{array}{l}4-0 z \\
\$ 0.50\end{array}$ & $\begin{array}{l}1-1 \mathrm{~b} . \\
\$ 1.50\end{array}$ \\
\hline Black Seeded Simpson & .15 & .50 & 1.50 \\
\hline Big Boston & .15 & .50 & 1.50 \\
\hline Prize Head & .15 & .50 & 1.50 \\
\hline May King. & . . .15 & .50 & 1.50 \\
\hline Salamander & .15 & .50 & 1.50 \\
\hline New York or Wonderful.... & .20 & .65 & 2.25 \\
\hline Iceberg. & .20 & .65 & 2.25 \\
\hline Lindholm's Hot Weather & .20 & .65 & 2.25 \\
\hline Mignonette & .20 & .65 & 2.25 \\
\hline Chicken Lettuce .................. & .15 & .50 & 1.50 \\
\hline $\begin{array}{l}\text { Lindholm's Best Mixed } \\
\text { Lawn Grass Seeds....1-11 }\end{array}$ & & & \\
\hline
\end{tabular}




\section{PEDIGREE MUSKMELON SEED}

EXTRA EARLY CITRON-A small, round or slightly flattened melon, valuable as an early market sort on account of its extreme earliness, hardiness and great productiveness. The skin is green, becoming yellowish at maturity. The flesh is light green and sweet. I have an excellent s' rain of this melon; it is earlier and larger than the old strain of extra early citron.

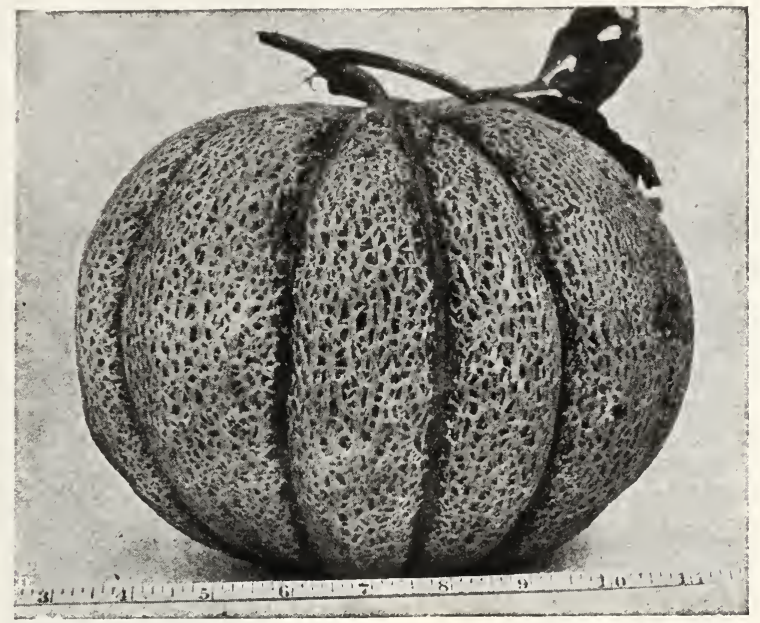

\section{Extra Early Citron}

EARLIANA, the New Muskmelon-We consider that there is no melon like it of the yellow-meated flesh variety for earliness, flavor and productiveness. We are firmly convinced that in addition to baing the earliest melon, and equal to any in flavor, it is by far the heaviest producer of mature fruit we have ever seen, a medium sized melon, nicely netted, flesh deep, sweet and melting, of golden yellow color. (Earliana is the same melon as Lake Champlain and Queen of the Earliest.)

HEARTS OF GOLD-The melons are almost perfectly round, thickly netted and very firm so they stand shipping well. The flesh is deep orange color, firm, very sweet and of delicious flavor. The melons are about the size of Rocky Ford. The vines are vigorous, free from blight and very productive. An excellent melon for shipping as it "holds up" well after picking. We have a fine strain of the true stock which produces melons of uniform size and high quality.

EX'TRA EARLY OSAGE-A week to ten days earlier than the old type Osage, and nearly as large; flesh very thick, salmon colored and of high quality. Form, color and general appearance similar to Osage. One of the very best melons we grow. 


\title{
MUSKMELONS
}

\author{
An Extra Early Melon
}

NEW GOLDEN OSAGE-An extra early melon, maturing from a week to 10 days ahead of the original Osage or the American Beauty.

We do not know of any large muskmelon or canteloupe quite equal to the New Golden Osage melon. It has exquisitely fine flavor; it grows to a large size and the melons are very firm and keep for a week after being picked.

The Golden Osage melons have a wide reputation for high quality among clubs and the best hotels. The seed was never offered by any dealer for a long time, but the public now has an opportunity to get seed that is of the genuine Golden Osage strain which we have grown and selected for years.

The flesh is deep orange colored, very thick, deliciously sweet and of high flavor.

The melons are of oval shape, cream colored with coarse netting. When ripe the melons turn a golden tint which shows through the netting and gives the fruit a very attractive appearance.

The size of the melons average quite large many weighing 10 pounds.

A valuable point about these melons is that they will keep a week after picking, and actually improve in flavor during that time.

For market and shipping this is an important consideration.

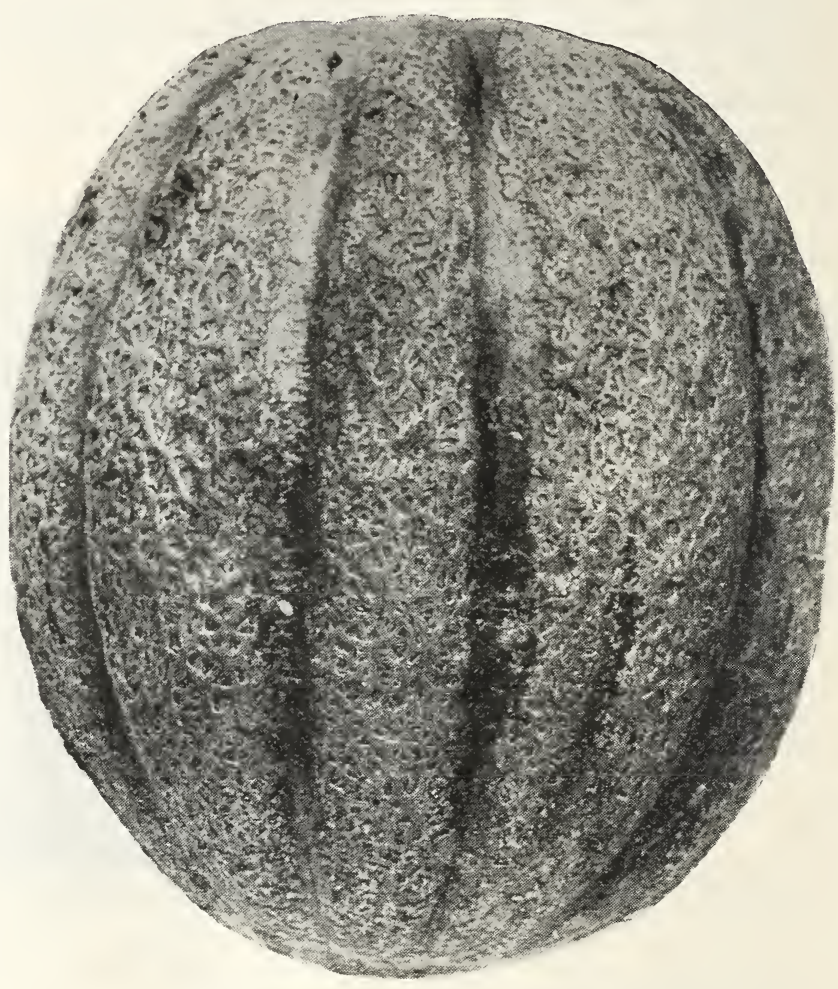

Golden Osage
HALE'S BEST - A remarkably early shipping melon from the Imperial Valley, Cal. Melons are oval in shape, about 6 in. long by $4 \frac{1}{2}$ in. in diameter, with heavy netting and fairly distinct ribbing. Flesh exceptionally thick and deep salmon in color. A most promising and profitable variety. 1 oz., $15 \mathrm{c}$; $1 / 4$ lb., 40c; $1 \mathrm{lb} ., \$ 1.50$.

In ordering Musk Melons remember to include our new Melon Ex Early Sunrise for the early variety and then the Golden Osage and the old fashion Osage late Melons for the market and the Sugar Rock and Hall's early best will be good Melons for the restaurants and the hotels.

\section{NOT HARD TO RAISE MELONS}

All that is required is a good rich, well manured soil, that is not too heavy, and a warm, sunny situation.

\section{THOMAS HYBRID OR IMPROVED} MILWAUKEE MARKET-It is exceptionally productive and especially fine flavored; very attractive appearance, medium in size and ripens medium early. The flesh is a deep salmon color, thick, firm and solid, and possesses a rich, aromatic flavor. Developed here and grown and marketed locally for a number of years. Milwaukee Market on account of its distinct and undeniably superior qualities has for sometime been recognized as a standard American variety of the first rank, and it is now grown by home and professional gardeners to the number of many thousands throughout the country. The fruit is very uniform in size, and every Melon is a good one, sweet and luscious to the rind. 


\section{MUSKMELONS}

\section{N E W G O L D E N} DELICIOUS MELON

-Fine flavor, large size and earliness combine to make this new melon a great favorite with market gardeners. The melons are of oval shape, light green, with coarse netting. As they mature they turn to a golden tint. Flesh deep orange, very thick, deliciously sweet, and of high flavor. Grows to a large size, weighing up to 7 and 8 lbs.

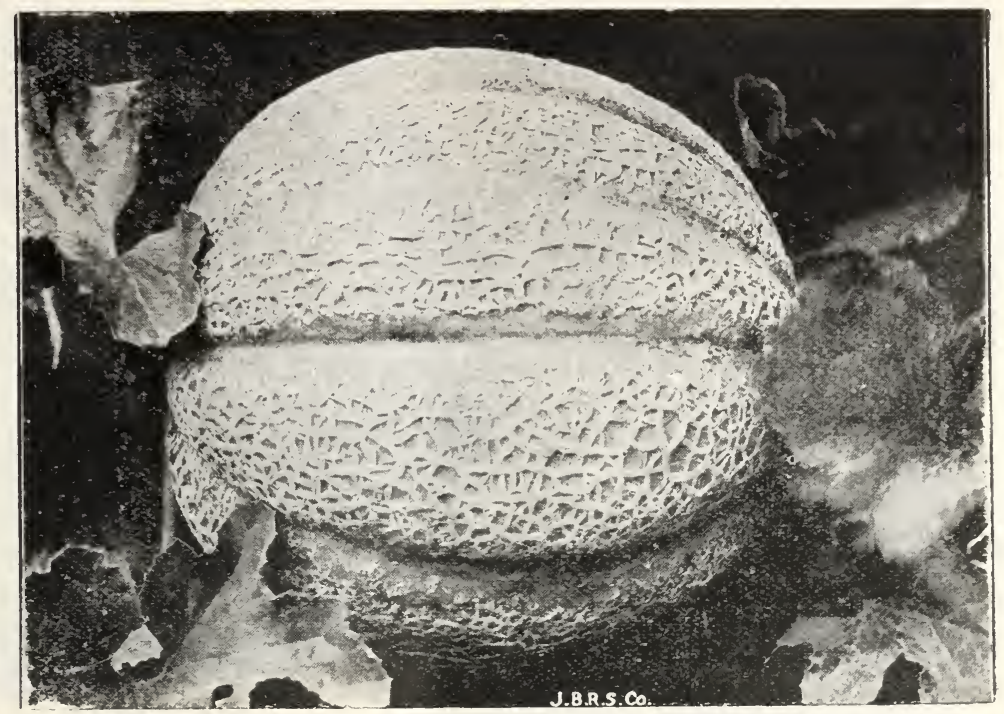

WHITE JAPAN-This variety, the New Golden Osage, American Beauty and early Netted Osage, are the only yellow-fleshed kinds grown to any extent in the West. The flesh is a thick salmon color, melting, and of a rich, sweet, delicious flavor. The fruits are of large size, nearly round, slightly ribbed and covered with patches of netting, skin yellowish white when ripe. Heavy yielder and good seller.

NETTED OSAGE- This Melon is one of my own production, having taken great care in harvesting the crop to exclude all melons not of the highest type. It has succeeded so well under such wide range of conditions, that $\mathrm{I}$ confidently recommend it to my customers as the best all-around melon for market or shipping. The quality and flavor are equal to the Osage, the flesh being a dark salmon, ripening clean to the rind. This melon does not burst when in a wet season like the Osage, and is just right for a market melon, being eight to ten inches in diameter. It is very heavily netted and fully a week carlier than the common Osage. I have an excellent strain of this melon which I have improved from year to year.

Netted Csage 


\section{MUSKMELONS}

AMERICAN BEAUTY-The American Beatuty Melon you will find the most pleasing and attractive Melon on the market today, being a great improvement over the White Japan. It has a rich salmon colored flesh, which is delicious as well as attractive. This melon has a heavy white netting, and skin which in color is clear yellow. I wish to introduce this melon to market gardeners as being one of $m y$ own production, bringing first prize at the Minnesota state Fair. It was pronounced far superior to any other melon, by the best judges and melon raisers in the State, and was picked from an assortment of twenty of the best melons on the market. We know of no other sort which will prove as large a seller and command as fancy a price. All gardeners who have never tried this melon should purchase at least a pound. The judges pronounced the American Beauty first; my Netted Osage

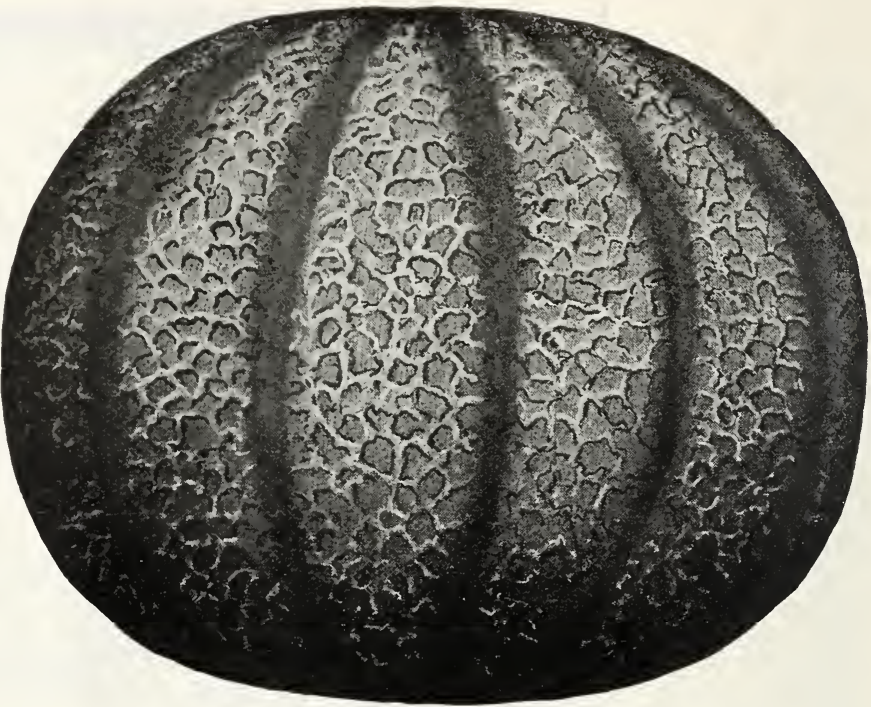
second.

GOLDEN HONEY DEW MELON-In every respect the same as the Green Fleshed Honey Dew, except the flesh is a rich golden color and ripens earlier. In order to develop it in this part of the country, start in pots under glass. On account of the delicious flavor, it commands a ready sale. It is the best keeper and slipper of all and will stay in good condition several weeks after it is ripe. Melons not ripe when frost comes may be stored in a cellar and will there ripen slowly and can be used all winter

IRONDEQUOIT - A fine yellow-fleshed melon. Vines are hardy and very productive. Melons are large, excellently shaped, distinctly ribbed and netted. The flesh is solid, very thick, with very small seed cavity. Rich salmon-yellow, sweet, and of a most delicious flavor.

EDWARD'S PERFEC'TO - A comparatively new melon, developed in Colorado as a shipper, and wil। hold its own in any market, both for quality and appearance. It is of the popular Rocky Ford size, solid salmon-tinted meat, beautifully netted.

EXTRA EARLY HAGKENSACK-Fruits are round, slightly flattened, with well-defined ribs and strong netting. Flesh is green, juicy, and of fine flavor.
BENDER'S SURPRISE-A very popular variety in the East, particularly around Albany, N. Y. A selection from Surprise and a close kin to Irondequoit, differing from that variety in being more oblong, more full and rounded at the ends, not quite as well netted or as early. A very delicious large, salmon-fleshed melon.

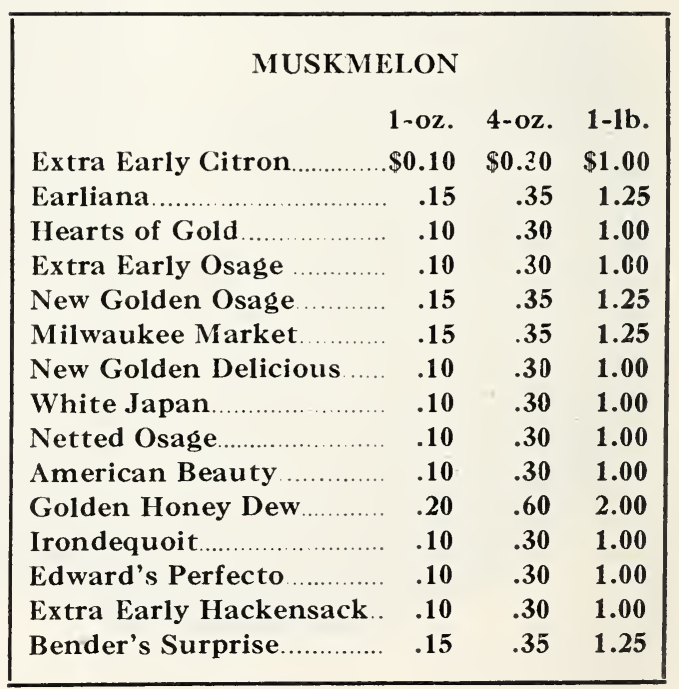




\section{COLORADO GROWN WATERMELON SEEDS}

KLECKLEY'S SWEET-There is no melon equal in quality to a good strain of Kleckley Sweet. It has a bright scarlet flesh, firm, crisp, and "sweet as sugar." We think by growing our seed in the north we have increased the earliness of the variety over the usual Texas or Florida grown stock. "Kleckley" is now only a few days later than Dark Ice Rhine. The melon is oblong in shape, about twenty inches in length by ten to twelve inches in diameter. The skin is a rich dark green, the rind is thin and brittle, and for this reason the melon is a poor shipper, but for the home garden and near market it is the very best.

DARK ICING - A nearly round Watermelon, with very thin rind. The seeds are white. The flesh is solid and of delicious sweetness. An excellent shipper, notwithstanding its thin rind. I know this to be one of the most desirable melons on the market.

HALBERT HONEY-A beautiful dark, glossy, melon of symmetrical shape and good size. A heavy bearer of fine fruits early in the season. Flesh of beautiful crimson color extends to within one-half inch of the very thin outer rind and is literally as "sweet as sugar."

IRISH GRAY - Color of rind yellowish gray. Wonderfully productive and a great keeper. The rind is almost as tough as a citron. Flesh bright, sparkling red, very sweet and firm. As good as Kleckley's Sweet and will carry three.thousand miles. Will produce one-fourth more Melons than Tom Watsons. Growth and vines more hardy and resistant than any other Melon. Bids fair to be a wonderful sort for home gardens as well as for shipping.

COLE'S EARLY-This is a very early variety of medium size and nearly round form. The skin is dark green, striped with lighter green. Hardy and very prolific.

\begin{tabular}{|c|c|c|c|}
\hline \multicolumn{4}{|c|}{ WATERMELON } \\
\hline & $1-o z$ & 4-oz. & $1-1 b$. \\
\hline Kleckley's Sweet.. &.$\$ 0.10$ & $\$ 0.25$ & $\$ 0.75$ \\
\hline 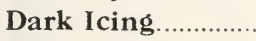 & .10 & .25 & .75 \\
\hline Halbert Honey. & 10 & .25 & .75 \\
\hline Irish Gray....... & .10 & .30 & 1.00 \\
\hline Cole's Early.... & .10 & .25 & .75 \\
\hline Winter Queen ........ & .15 & .35 & 1.25 \\
\hline Long Light Icing.. & .10 & .30 & 1.00 \\
\hline Tom Watson... & .10 & .25 & .75 \\
\hline Citron. & .10 & .25 & .75 \\
\hline
\end{tabular}

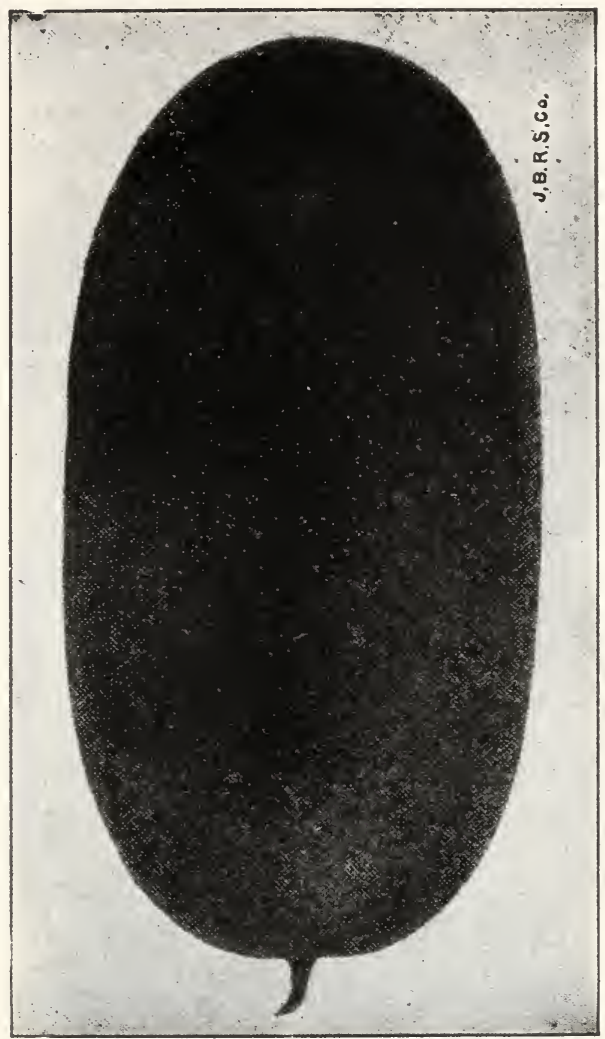

Kleckley's Sweet

WINTER QUEEN - Also called "Honey Dew." This is an exceptional melon for fine keeping quality; put in a cool place it keeps long into the winter and retains its delicious sweetness and flavor.

LONG LIGHT ICING-Also known as Gray Monarch. The fruits are long and large, light green, slightly veined with a little darker shade. The flesh is deep, rich red, and of splendid quality. Seed white.

TOM WATSON-A large oblong Melon, that has become a great favorite everywhere. The flesh is a bright attractive red, of delicious flavor.

CITRON FOR PRESERVES-Medium-sized fruits used for preserves and pickling. Ripens in the fall and can be kept in good condition for a long time. 


\section{SUPERIOR ONION SEED}

SOUTHPORT LARGE RED GLOBE-All grown from selected hand-picked bulbs, none but those perfect in size and shape being set for seed. Onions large and handsome, globe shaped and color a purplish crimson. It is a good keeper and always realizes high prices. Michigan grown.

MICHIGAN, OR OHIO YELLOW GLOBE-Finest shape, best color and yields the largest crop of any yellow onion. The bulbs are large, almost globeshaped, the largest diameter below the center of the bulb. Neck very small, color rich orange yellow. It is an enormous yielder and a splendid keeper.

SOUTHPORT WHITE GLOBE-A large, globeshaped onion; firm, fine grained, of mild flavor; keeps well. This is one of the handsomest onions grown, of beautiful shape, clear white skin, and commands the_highest market price. Michigan grown.

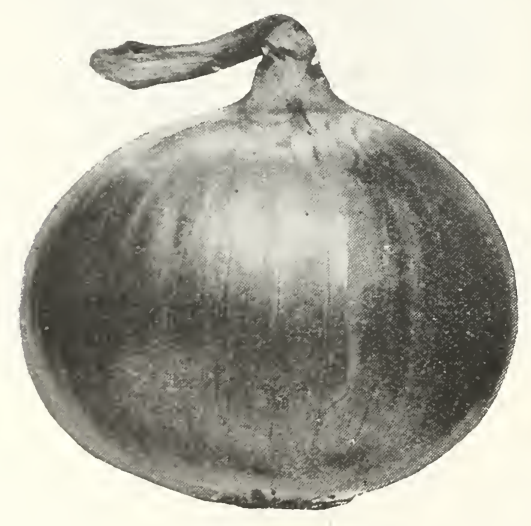

White Globe

SOUTHPORT, YELLOW GLOBE-The most beautiful Yellow Onion of fine globe shape, golden yellow color, large size, mild flavor, a heavy cropper, an excellent keeper and good shipper. Our strain will be found a good deal earlier than the old Southport variety. The best yellow variety to grow for the market

YELLOW GLOBE DANVERS, OUR FINEST STRAIN - This, our special strain, is all grown from carefully selected, hand-sorted bulbs and is immeasurably superior to most stock offered under this name.
AUSTRALIAN BROWN-This is a variety possessing remarkable keeping qualities. These onions have been kept in perfect condition the year around - the onions are of medium size, somewhat flattened, and of a light reddish brown color. They mature very early, being two weeks earlier than Yellow Danvers.

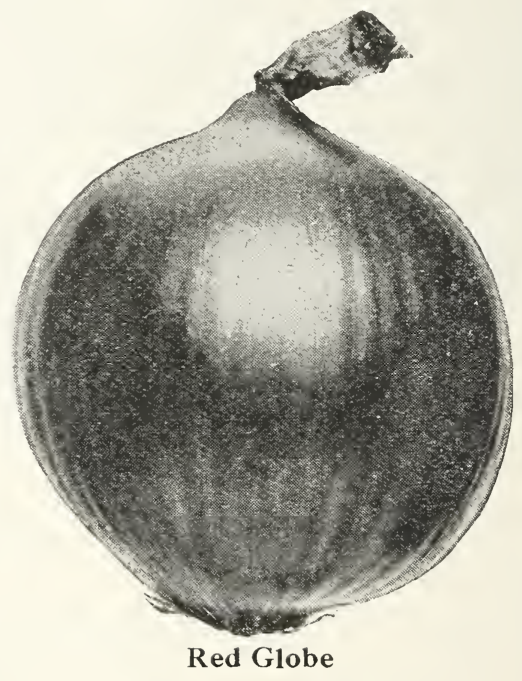

JAPANESE OR EBENEZER-A very fine round, yellow onion that will keep all winter and is of mild, pleasant flavor. The seed is used principally for raising sets, which when set out the following spring produce large, handsome, ripe onions in July.

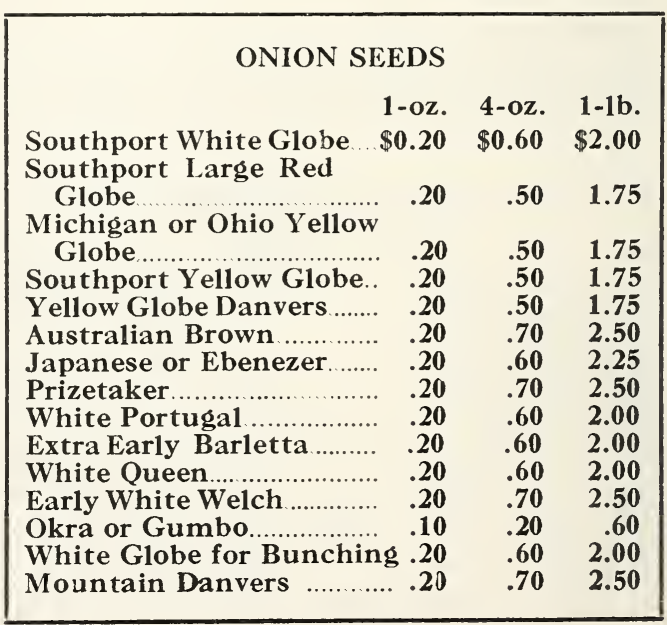


PRIZETAKER-American Grown-Amongst the large onions this one is exceptional for size and beauty -it is of the same type as the large Spanish onions, imported and sold for high prices.

Prizetaker is a yellow globe that matures to great size under right conditions; it requires a long season and should be started early in hotbed. When properly ripened it is a good keeper.

\section{WHITE PORTUGAL OR SILVERSKIN-Is a} highly favored onion by the great number of planters who use it, as well as by the consuming public. It is extensively used for growing White Onion Sets and Pickles, and also for early Bunching or Green Onions; for either of these purposes it is very good.

WHITE GLOBE-Used for green bunch onions large, globe-shaped bulbs of a pearly white color The flesh is firm, fine grained and of mild flavor. Used extensively for a green bunch onion, for which it is admirably adapted on account of its strong top and handsome shape. One of the best and most popular sorts. We have dropped the Early White Bunching on account it does not give satisfaction.

EX'TRA EARLY BARLETTA-The handsomest and most perfect white pickling onion grown. When sown thickly the onions mature about the size of a cherry, perfectly round, white and of very mild flavor.

WHITE QUEEN-A very early, very white, clean skinned variety used for bunching when young, and one of the very best for small white pickles.

EARLY WHITE WELCH ONION-The best kind for green onions; it forms no bulbs. A very hardy perennial variety of onions used for bunching or for early green onions. The shoots attain marketable size very quickly and sell at top prices before the green onions grown from sets are brought, to the market. Much superior to the Egyptian onion. Sow seed thinly in rows 12 to 16 inches apart. Seed may be sown in late summer or late fall months for early spring onions. Market gardeners will find the White Welsh Onion an exceedingly profitable crop.
MOUNTAIN DANVERS ONION-A very early maturing strain of Yellow Globe onion originating in the mountains of Colorado. The onions are of fine globe shape, deep yellow color and very firm. They ripen two or three weeks earlier than Yellow Globe Danvers, and are valuable on this account where the seasons are short. These onions have remarkable keeping qualities and can be safely stored all winter. They do not get quite as large as the Yellow Globe Danvers, but are of good size and are often found more profitable than the later kinds because they can be marketed before other kinds are ready. Muck growers find it profitable to plant a portion of their onion acreage in Mountain Danvers.

\section{ONION SETS}

It is impossible, as this catalogue is written, to fix prices for sets. We follow the market and will fill orders at market prices. In bushels or 10-bushel lots. Please write for prices; we have excellent sets this year.

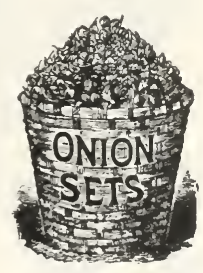

White Bottoms

1b. $\$ 0.20$

Ebenezer

lb. .20

Red Bottoms.

1b. .20

Yellow Bottoms.

lb. .20

\section{OKRA, OR GUMBO}

PERKINS' MAMMOTH-This variety is about 3 feet high, very early and productive. Pods are deep green, very long, slender, slightly corrugated, very tender, and of good quality. A fine market variety. 


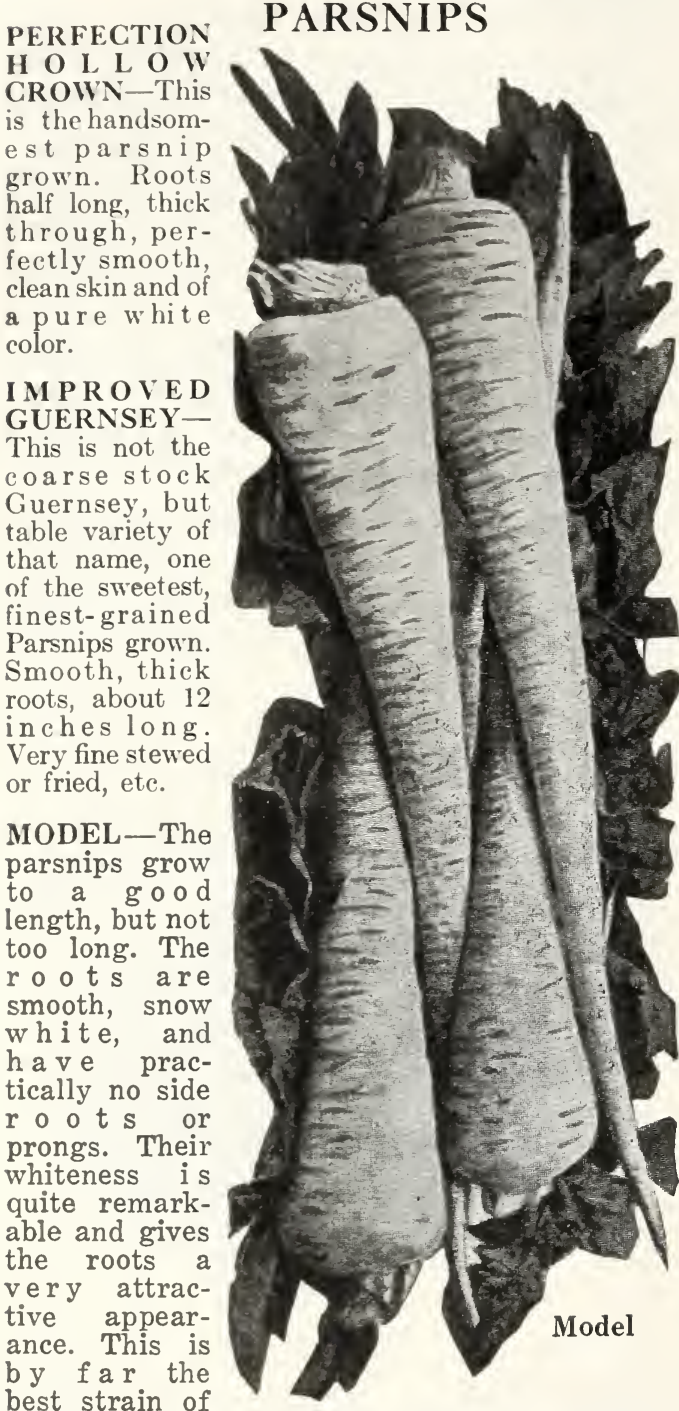

best strain of parsnip we have seen. The roots are uniformly of nice shape, very white, smooth, and handsome. This is largely due to the fact that our seed of this variety is all grown from transplanted roots and only the best shaped roots are used.

\section{PARSLEY}

CHAMPION MOSS CURLED-Plant very robust and is greatly improved by severe cuttings. The leaves are large and beautifully curled and of a very dark green. It stands heat, drought and cold better, and will yield double that of any other sort. The parsley for either the market or family garden. HAMBURG ROOTED-Ihe root resembles a small parsnip and is the edible part of this sort; extensively used for flavoring soups.

\section{PUMPKINS}

GOLDEN LONG PIE PUMPKIN-The Golden Long is a very fine pumpkin; more used in the market than all others put together. It is not to be compared with Burpee's Oblong, as this is longer, with a better shape and color. The pumpkin that gives satisfaction to market gardeners. I have an excellent strain of this seed.

SUGAR OR NEW ENGLAND PIE-For making pies this variety cannot be excelled. The pumpkins are small, but very sweet, fine grained and of the best quality. The skin is a deep orange and flesh rich yellow.

WINTER LUXURY, OR IMPROVED SUGARGrows a little larger than "Sweet Sugar," and the fruit is without ribs, lighter yellow and netted like a muskmelon. The flesh is thick and of fine quality, and they will keep all winter if properly stored. A very fine pumpkin for home use or market.

CONNECTICUT FIELD-An immensely productive, large, orange-colored field pumpkin, usually grown for stock feeding, but also making good pies. There is no variety that will do so well among the corn. Plant them on your richest land and you will be amply repaid.

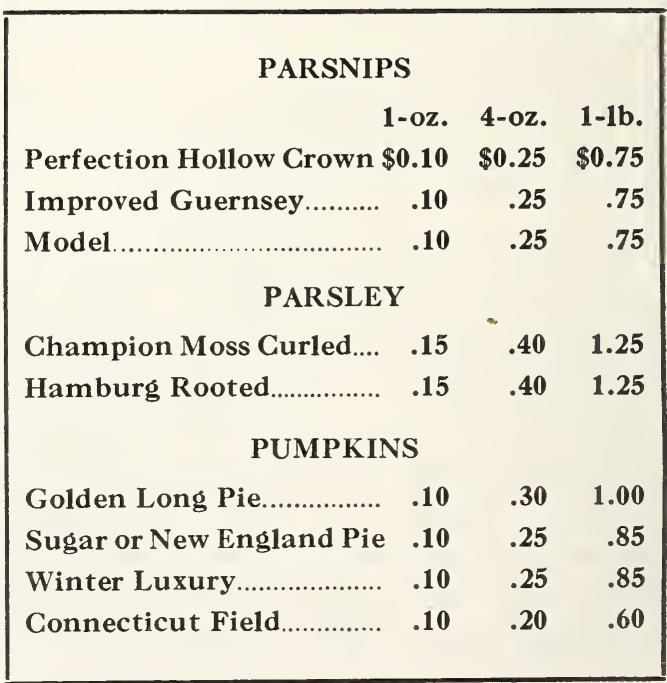




\section{SWEET PEPPERS}

\section{For Stuffing and Flavoring}

CHINESE GIANT PEPPER-This desirable variety is undoubtedly the largest Sweet Pepper ever offered. The flesh is quite thick, very mild and remarkably sweet.

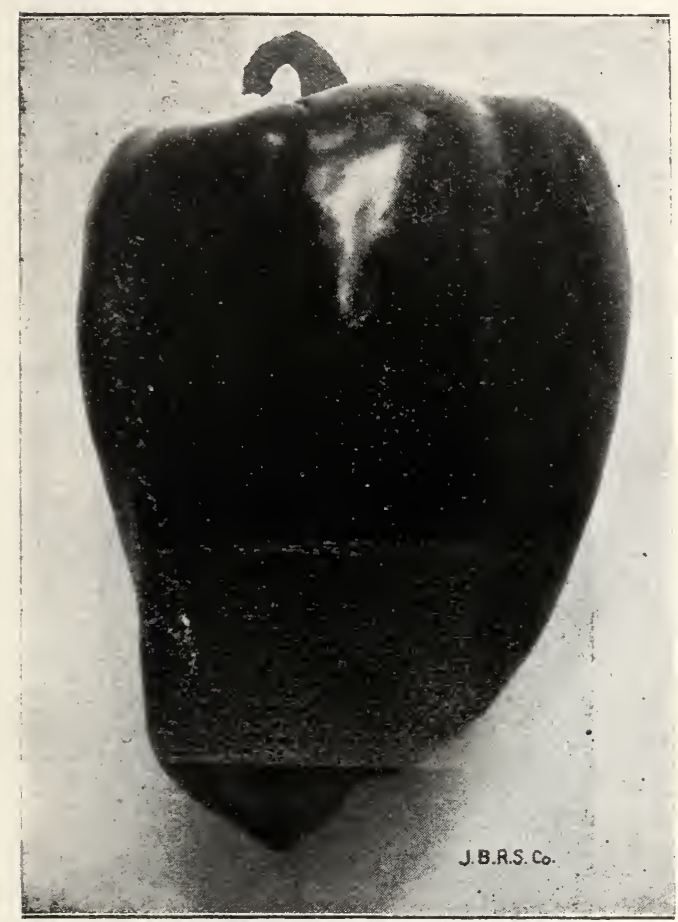

\section{Harris Early Giant}

WORLD BEATER - One of the best large, midseason peppers, with thick, sweet flesh. Fruits extra large measuring nearly 6 inches long by 4 inches through, of a rich ruby color. This strain is very productive and plants bear large quantities of the handsome fruits.

\begin{tabular}{|c|c|c|}
\hline \multicolumn{3}{|l|}{ SWEET PEPPERS } \\
\hline & 1-oz. & 4-oz. \\
\hline Chinese Giant.. & $\$ 0.50$ & $\$ 1.75$ \\
\hline Grimson Giant.. & .50 & 1.75 \\
\hline World Beater... & .50 & 1.75 \\
\hline Large Early Neapolitan & .50 & .175 \\
\hline Oshkosh Pepper. & 1.00 & 3.50 \\
\hline Harris' Early Giant... & .. .50 & 1.75 \\
\hline Sunnybrook Pimento & .. .50 & 1.75 \\
\hline Jersey Giant.. & .. .75 & 2.50 \\
\hline Improved Thick Long Red............. &. .50 & 1.75 \\
\hline
\end{tabular}

CRIMSON GIANT OR OHIO CIRIMSON-One of the earliest of the very large varieties. The flesh is mild and very thick. The plants are very vigorous and heavy yielders. The color is deep green, turning to a deep crimson when matured.

LARGE EARLY NEAPOLITAN-Decidedly the earliest of all large mild red pepper, and the most productive of all large peppers. The fruits measure 4 inches long and $4 \frac{1}{2}$ inches in circumference. The strong, vigorous plants grow 2 feet tall by 18 inches across. They are heavily laden with large handsome fruits and bear continuously until frost.

OSHKOSH PEPPER - Yellow peppers are usually not very popular, but this new variety is of such exceptional merit that we feel sure it will be largely grown when gardeners find out what it is.

The peppers, before they mature, are of a deep green, large, smooth and of the best shape for stuffing. When ripe the color is a deep golden yellow. The flesh is exceptionally thick-more so than any other large pepper that we know of.

HARRIS' EARLY GIANT - Is not only very large, but the plants produce enormous yields and the peppers mature earlier than any other very large kind with which we are acquainted. The plants are of vigorous growth, often being 18 inches to 2 feet tall, and covered from top to bottom with enormous peppers.

SUNNYBROOK PIMENTO - The smooth fruits average 3 inches in diameter and 2 inches long and are produced in clusters of 4 or 5 on dwarf broad bushes. The peppers are of a rich attractive deep scarlet color.

JERSEY GIANT - This is the earliest of all large Peppers, almost as large as Chinese Giant and three weeks earlier; plant of dwarf branching habit, bearing 12 to 15 fruit of a deep green color, turning to brilliant red, flesh thick and of mild flavor.

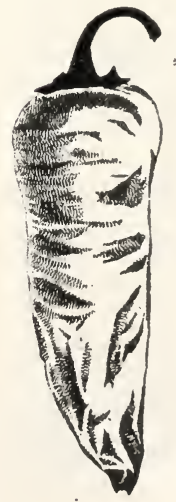

IMPROVED THICK LONG RED

-A great improvement on the ordinary Long Red Cayenne. Pods of about the same length, but much thicker. The flesh is fully double the thickness. They are grown almost exclusively for some markets. Exceedingly prolific, are very hot and have handsome bright red pods Produced early in the season while prices are high. 


\section{OUR MICHIGAN GROWN, HARDY, VIGOROUS SEED PEAS WILL ALWAYS GIVE BEST RESULTS}

P E D I R E E EXTRA EARLY -is the purest strain of very early Peas ever offered to the trade. The pods are good length and well filled, and the strain is prolific, exceptionally uniform in growth and free from spots. It is without question the best strain of Extra Early Peas ever offered to $t \mathrm{~h} \mathrm{e}$ trade.

\section{A X T O N'S} PROGRESS The latest and by far the best of $t h e$ largepodded large fruited wrinkled peas, growing on d warf vines which are the sweetest, a nd best yielding e a $r$ y varieties. Of all the varieties producing

peas of equal quality, this is the heaviest yielding. It bears long pods, averaging one more pea to the pod than Hundredfold, Pioneer and Laxtonian. It is an improvement upon Laxtonian, which has hitherto been the finest of the dwarfs for table quality.

THOMAS LAXTON-This fine pea very closely resembles the Gradus in size of pod and peas; the pod is of a darker color. Mr. Laxton considers it earlier than Gradus. We find it earlier and a better producer, but pods not quite as long as Gradus.

GRADUS OR PROSPERITY - A grand, early, large-podded wrinkled pea. Has become one of the favorites with truck growers in nearly every section of the country. Pods are from 4 to $4 \frac{1}{2}$ inches in length and the peas are unusually large, very sweet and of delicious flavor.

MARCHIONESS - A very valuable addition to the tall early varieties. It may be briefly described as an Extra Early Gradus. The pods are of equal size to Gradus and the season several days earlier. Quality superlative; plant this and be the first on the market with a good sized quality pea.
WORLD'S RECORD-An improved type of Gradus, being slightly earlier, more dwarf, true, to type and productive. Height 2 feet. Vines moderately stout, medium green; pods medium green, 4 inches long, fairly broad, pointed and well filled with 7 to 9 very large, dark green peas of exceptional quality.

LAXTONIAN - A large podded, dwarf variety on the order of Gradus, though more dwarf and a little earlier. Height 11/2 feet; pods and vine deep green; pods $33_{4}$ inches long, straight and pointed, containing 6 to 8 large, dark green peas.

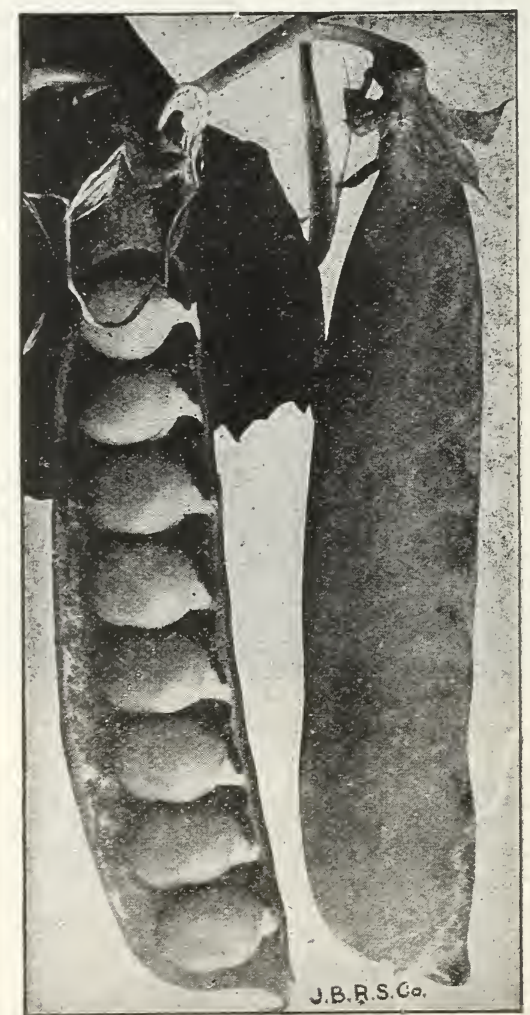

Improved Laxtonian

IMPROVED LAX'TONIAN - This new, large podded, early wrinkled pea is in great favor with market gardeners in all sections. The handsome large pods, which are well filled with big peas of delicious flavor, make it a good seller on the market stall. The vines are extremely vigorous, growing only fifteen to eighteen inches high, with dark green foliage, and produce a wonderful crop of pods. 
HUNDREDFOLD-Decidedly the best of the Laxtonian types; vine 16 inches high, sturdy, dark green and productive; pods dark green, 4 inches long, fairly broad and pointed containing 8 large, dark green peas; excellent quality.

LITTLE MARVEL-A grand sort for the home garden, being a good cropper. Makes a good pod and a short vine. It has all the qualities found in any variety.

AMERICAN WONDER - A dwarf, early wrinkled sort; pods short but well filled, quality excellent; height 1 foot.

PIONEER - A new Giant Podded, first early pea which has won great popularity. The plant is unusually robust in habit, and carries a heavy crop of long, pointed pods of dark green, which are well filled with rich-flavored peas.

MELTING SUGAR-Large Edible Podded Late Sort, a great favorite, white seeded sugar pea, with those who have once used them. Plants grow 5 feet high, producing handsolne large pods in 70 days, which when cooked resemble wax beans; tender and delicious.

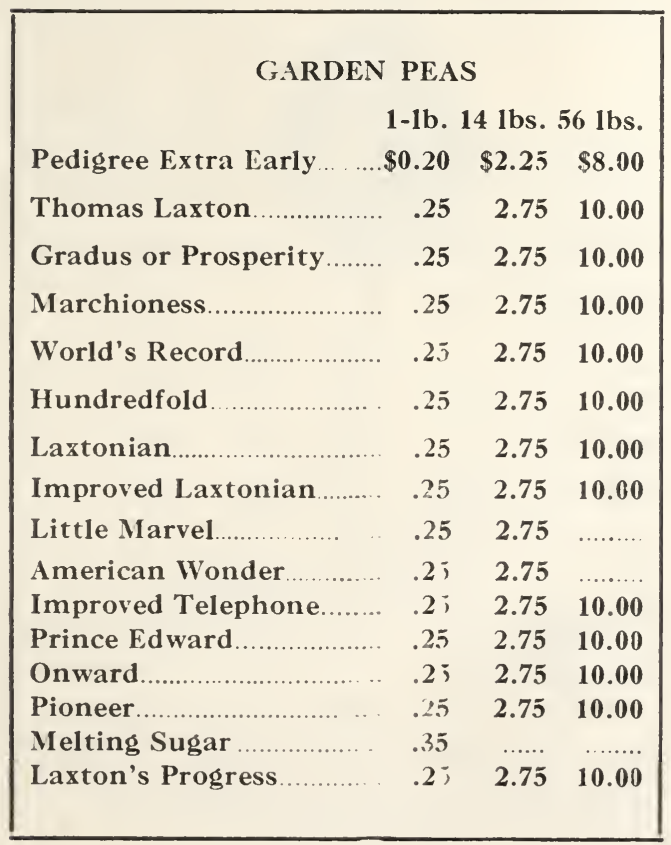

IMPROVED TELEPHONE

-Of the tall growing varieties of late peas, Improved Telephone is regarded by experienced and successful growers as the best sort for general purposes. In the home garden its value is attested by heavy yielding and excellent quality. Uniformly large pods, 5 inches or more long, filled with 8 to 9 delicious peas. The fine rich, dark green color of the pods gives them highest market value. The crop maturing evenly makes only a few pickings necessary, and insures the gardener a good profit.

\section{PR I N GE ED W A D - A} strain especially selected for large pods. The largest podded of all the Telephone types. Is ready for pickingat the same time as the well known Alderman, which it closely resembles, but with considerably larger pods. Market gardeners find this and the Admiral Dewey the two best late peas on the market.

ONWARD - A very distinct and valuable new mid-season variety, coming in just ahead of Telephone. A heavy cropping pea, $2 \frac{1}{2} \mathrm{ft}$. in height, with vigorous, strong, medium-

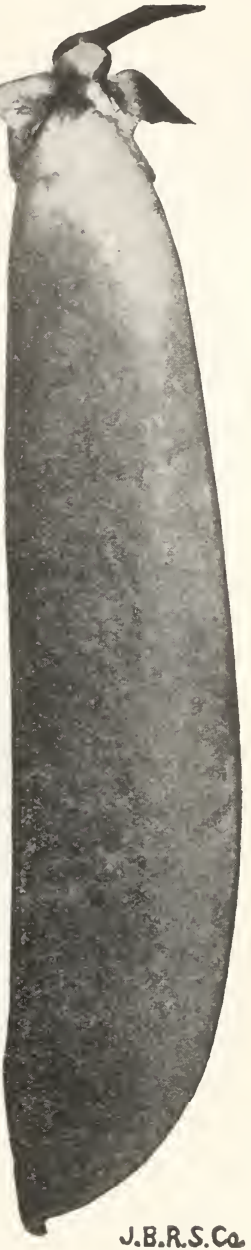

Improved Telephone green foliage. Pods are 4 inches long, large, broad, straight and blunt ended, deep green in color. Decidedly the best pea of recent introduction.

We carry Seed Potatoes in the spring. Early Ohio, Early Triumph, Irish Cobbler, Green Mountain, and Russet Burbank. Write for prices. 


\section{RADISHES}

Some of our radish seed is grown from transplanted roots and is sure to give excellent satisfaction. Extremely early; brilliant color; small top and tap root; uniform shape; good quality.

EARLY SCARLET GLOBE-Select Stock-This stock is grown from transplanted roots. Each root is inspected for shape and color, with an endeavor to secure a very uniform stock. We believe critical growers will find this stock equal to any offered either for growing outside or in the greenhouse. It is a very early and quick growing radish; all the small seeds are taken out so all the seeds are of the same size. This will make them come up more strong and even and you will hardly lose a single seed.

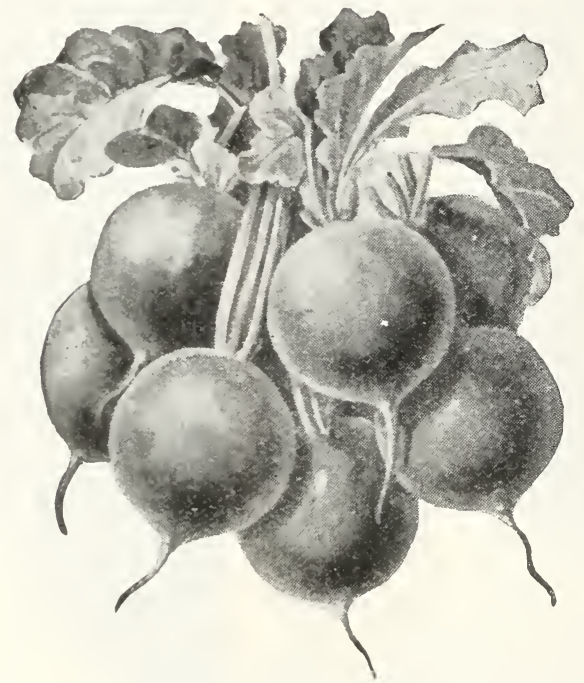

Scarlet Gloke

IMPROVED EARIY SCARLET GLOBE-The leading variety of radishes with market gardeners; equally as good for forcing in greenhouses and hotbeds as for open garden culture. Almost exclusively grown by market gardeners near the Twin Cities. A very handsome radish of rich, bright scarlet color and oval shape, with very small tops; the flesh is delightfully crisp, juicy and tender. An extra early variety fit to be pulled in about three wecks. This is also from transplanted roots.

\section{SPARKLER EARLY SCARLET TURNIP-} WHITE TIPPED - One of the most attractive and popular of the early turnips. The roots are slightly flattened, the upper portion a deep scarlet and the under portion white, making a beautiful contrast. Our stock of this important variety is true and can be relied on to be the best of its class.

RICE'S SAXA-The earliest of the forcing radishes, and one of the slowest to shoot to seed. Round, bright scarlet and with smallest possible top. We have an excellent stock of this radish and can highly recommend it.

CRIMSON GIAN'T - A large, early round sort of the scarlet Globe type. Grows twice the size, but is a little later and has more top, which makes it undesirable for forcing, but an excellent outdoor sort. It remains solid longer than any of the early round red varieties. Color bright red.

WHITE ICICLE-White Icicle is the finest of all the long varieties and is claimed to be the finest of all radishes. The roots are crisp and tender, even when fully developed, and they have an agreeable snappy flavor. The roots grow to good size, 5 inches long, and are the shape of an icicle. They are straight and free from any side roots.

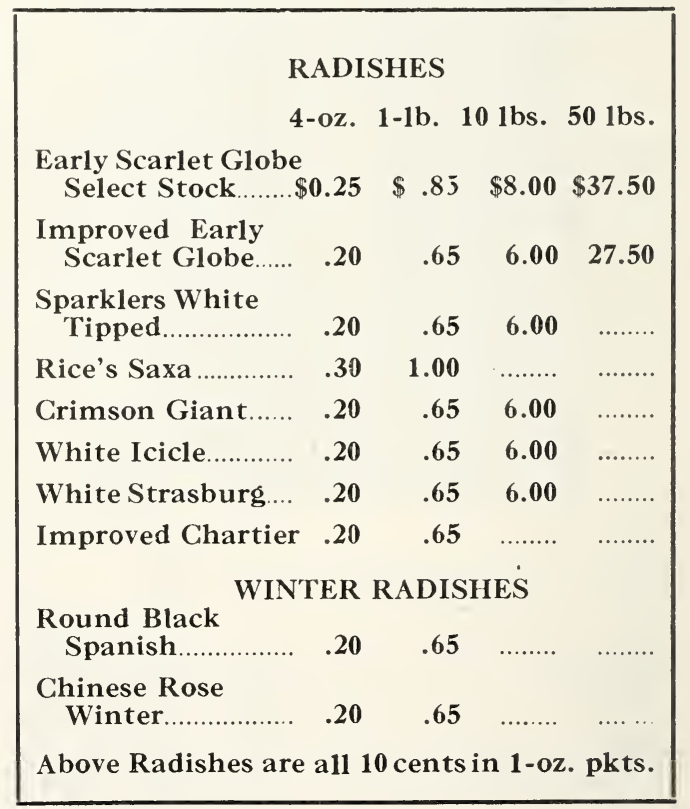

Radishes from transplanted stock scarce this year---Must be ordered early. 


\section{RADISHES}

WHITE STRASBURG-One of the most popular summer sorts. Roots long, quite thick through. Color white. It remains solid for a long time after reaching maturity.

IMPROVED CHARTIER-A distinct and exceedingly attractive sort; a clear rose colored long radish, shading into pure waxy white at the tips. Attains very large size. Perhaps one of the best all-seasons Radishes for the open ground.

\section{Winter Varieties}

ROUND BLACK SPANISH-The roots are round' sometimes slightly top shaped, three or four inches in diameter. The skin is almost black. The flesh is white, very compact, decidedly pungent, but well flavored. The variety keeps well through the winter.

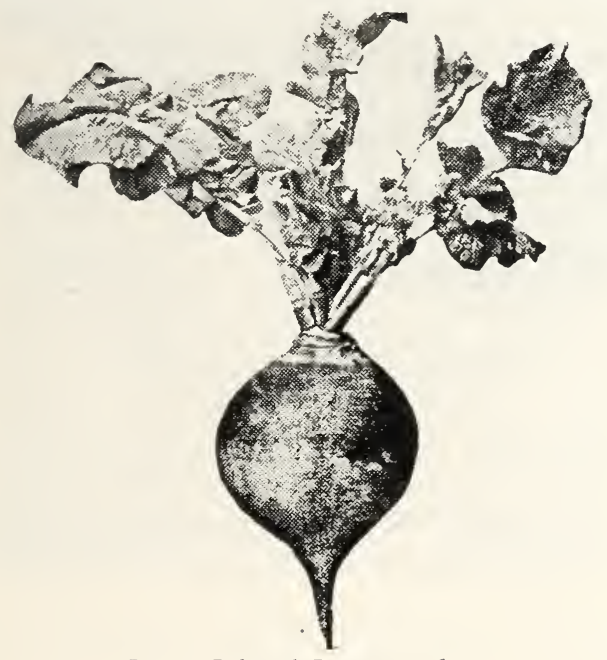

Long Island Improved

\begin{tabular}{|crrr}
\multicolumn{5}{c}{ RUTABAGAS } & \\
1-oz. & $4-0 z$. & $1-1 b$. \\
American Purple Top.......\$0.10 & $\$ 0.25$ & $\$ 0.75$ \\
Long Island Improved ...... & .15 & .30 & 1.00 \\
$\begin{array}{r}\text { Zwaan \& DeWiljes' Elite } \\
\text { Yellow Purpletop............. }\end{array}$ & .10 & .25 & .85 \\
\hline
\end{tabular}

CHINESE ROSE WINTER-A handsome and superior mid-summer, fall and winter sort of a lovely scarlet-rose color, and large size. Flesh meaty, crisp and tender. Keep roots in soil for winter use.

\section{Rutabagas, or Swedish Turnips}

AMERICAN PURPLE TOP-This type of rutabagas has been grown in this country for a hundred years. Comstock, Ferre listed it in 1834. The American strain is a selection from the old English type. It has been selected for a smaller top and shorter neck than is usually found in England. The roots are globular, but grow to a large size and are of splendid quality. An excellent sort for either table use or stock feeding.

LONG ISLAND IMPROVED-This stock renowned for its fine round shape, bright yellow color, one grain and sweetness. Matures rapidly and has practically no neck. Our original stock seed came from Mr. Neylon of Long Island. For many years Mr. Neylon has been selecting a few perfect specimen rutabagas which conform to a perfect type, and he has produced the seeds therefrom. In following this practice over a long period of years he has produced one of the finest rutabagas we have ever seen. Rutabagas grown from this seed for a number of years have had a ready sale in New York markets at 50c to $75 \mathrm{c}$ per barrel above all other stocks.

ZWAAN \& DE WILJES' ELITE YELLOW PURPLETOP - A quite distinct variety of our own selection, with which we had a great success in our country. It has a smaller top than the English varieties, but in general a heavier root, and is practically neckless. The shape is globular, the color deep purple. The small foliage allows close planting and as this variety works principally on the root and but few on the leaves, the yield per acre is enormous. Although it is early in maturity, it will keep in splendid condition until quite late in the spring. The quality of the flesh is superb, richly colored, fine grained and when cooked very tender and sweet. 


\section{SPINACH}

PRINCESS JULIANA-Those who have tried this new spinach know it is a wonderful improvement over all other kinds. It not only grows fast and produces a large vield, but it stands two weeks longer before running to seed. The leaves are broad, heavy dark green, and somewhat blistered like a Saroy cabbage. The remarkable thing about it is that it stands so long before putting up a seed stalk. This is a great advantage to the gardener.

GIANT FILLBASKET-The very largest Early Spinach, the result of careful re-selection. In Europe it holds first place in public favor. Our customers here have had great success with it and are planting it more extensively each year. Its broad, thick, light green leaves are very crisp and tender and of delicately delicious flavor.

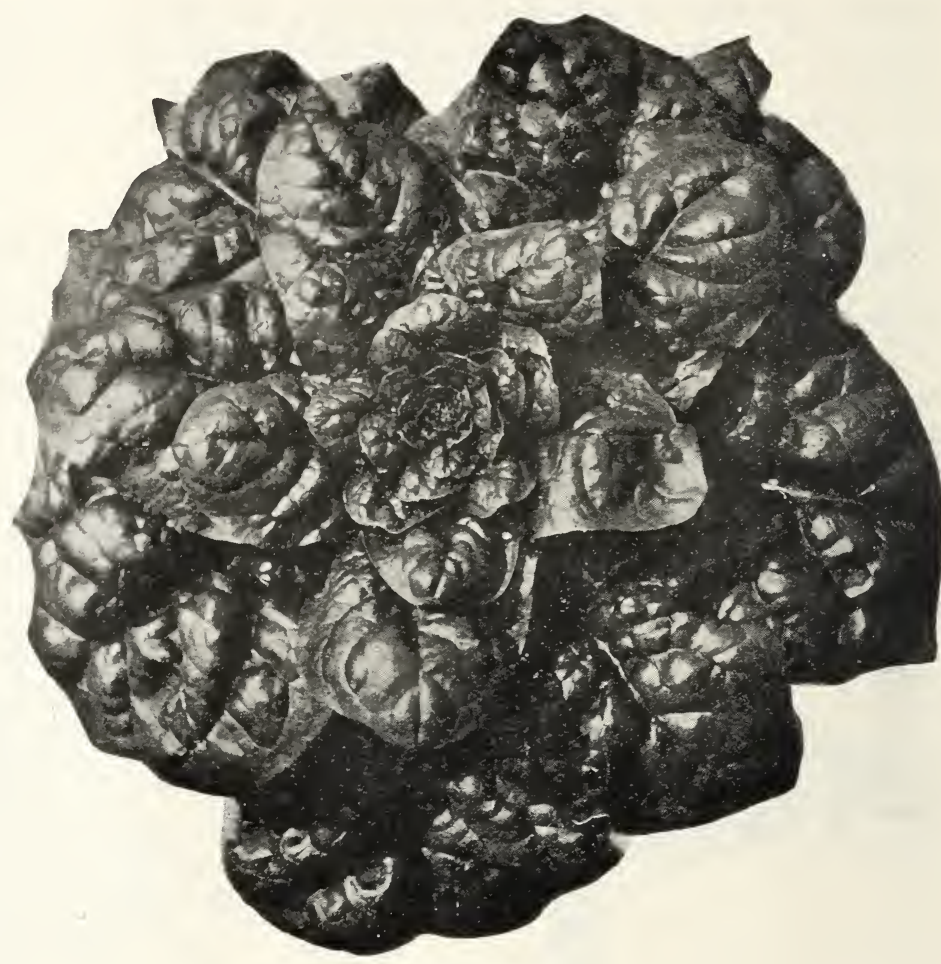

Princess Juliana

BLOOMSDALE EXTRA EARLY-This is the variety so highly prized by the gardeners around Minneapolis and St. Paul for the very earliest planting. Large wrinkled leaves, upright growth; fine quality; earliest variety; but will not stand long.

NEW LONG-STANDING BLOOMSDALE-A new strain of outstanding merit. It is just as early and quick-growing as the old Bloomsdale, but it will stand in a marketable condition 10 to 14 days longer before bolting. It is crumpled and blisted and very uniform. The color is a deep glossy green. Wherever Bloomsdale is grown, this improved strain will get far more satisfactory results.

SUMMER GREEN LONG STANDING-The finest variety to sow for a second crop or through the summer months, as it stands hot weather remarkably well. The plant is large, leaves thick, dark green and very much crumpled.
VICTORIA - Noted for its dark green leaves. It will outyield every other variety and at the same time stand longer without going to seed-very desirable for market.

\begin{tabular}{|c|c|c|c|}
\hline \multicolumn{4}{|c|}{ SPINACH } \\
\hline \multicolumn{4}{|c|}{$1-1 b .101$} \\
\hline Princess Juliana .................... &.$\$ 0.30$ & $\$ 2.50$ & $\$ 11.25$ \\
\hline Giant Fillbasket & .. .30 & 2.50 & 11.25 \\
\hline All-Season & .. .30 & 2.50 & 11.25 \\
\hline $\begin{array}{l}\text { Bloomsdale Extra Early... } \\
\text { New Long Standing }\end{array}$ & .30 & 2.50 & 11.25 \\
\hline Bloomsdale & 30 & 2.50 & 11.25 \\
\hline Summer Green I ong & & & \\
\hline Standing & .30 & 2.50 & 11.25 \\
\hline Victoria & .30 & 2.50 & 11.25 \\
\hline
\end{tabular}




\section{SQUASH}

HUBBARD - Large, hard dark green, heavily warted skin, thick-fleshed and a heavy cropper. A favorite with the market men and shippers. Our strain of Hubbard is considered to be the finest of any grown. The fruits grown from our seed matures earlier, keeps better and commands a higher price than seed grown down east.

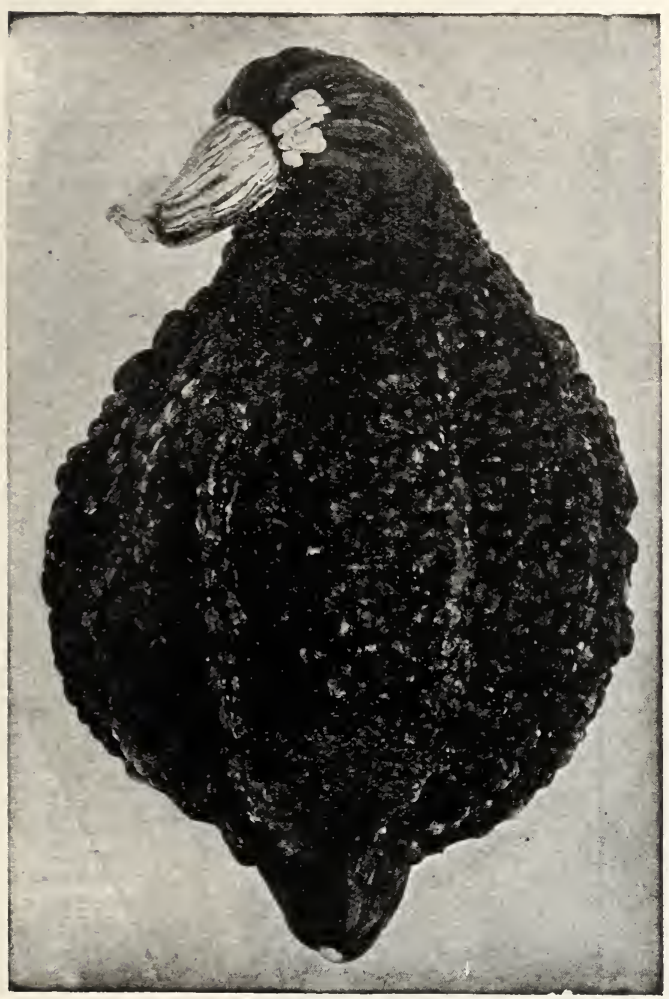

Hubbard

\begin{tabular}{|c|c|c|c|}
\hline \multicolumn{4}{|c|}{ SQUASH } \\
\hline & $1-o z$ & 4-oz. & $1-1 b$. \\
\hline Warted Hubbard & $\$ 9.15$ & $\$ 0.40$ & $\$ 1.59$ \\
\hline Blue Hubbard ... & .15 & .49 & 1.53 \\
\hline Golden Hubbard. & .10 & .35 & 1.25 \\
\hline White Bush & .10 & .35 & 1.25 \\
\hline Giant Summer Crook & & & \\
\hline Neck... & .10 & .35 & 1.25 \\
\hline Delicious ........ & .10 & .35 & 1.25 \\
\hline Great Chili & .10 & .35 & 1.25 \\
\hline Table Queen. & .10 & .35 & 1.25 \\
\hline Quality.... & .20 & .70 & 2.50 \\
\hline
\end{tabular}

BLUE HUBBARD - A new variety obtained by selection from the original Hubbard. The fruit is of a gray-blue color, grows very large and keeps remarkably well as the shell is extremely hard. The quality is equal to or even better than the original Hubbard.

GOLDEN HUBBARD - Similar to Hubbard, except that it is smaller, matures earlier and is of an orangered color, except for a bit of olive green on the blossom end.

WHITE BUSH - A very early and fine type of Bush or Scallop. Much larger and better in every way than the older types.

GIANT SUMMER GROOK NECK - A new crook neck, which is a little earlier than the old variety, and fully twice as large, being nearly two feet in length. It is of extra fine quality, handsome in appearance, and finds a ready sale at good prices in any market.

THE DELICIOUS - Surpasses all other varieties in richness and flavor, fineness of grain and thickness of flesh. About the same size and outside color as Hubbard. Flesh deep orange.

GREAT CHILI-This squash grows to an enormous size and often weighs $200 \mathrm{lbs}$. and more. It is very prolific. The skin is of rich orange yellow color. It is largely used for stock feeding, but also for exhibition purposes.

TABLE QUEEN - This is considered a great delicacy - cut in half and baked for twenty minutes, it makes a delicious meal. Also very nice for pies. This is what is called an individual squash, being quite small; six to seven inches long, by four to five in diameter. The shell is hard and smooth, so that they keep as well as the Hubbard. The color is dark green, with sometimes a blotch of red at stem end. This variety is getting more popular from year to year.

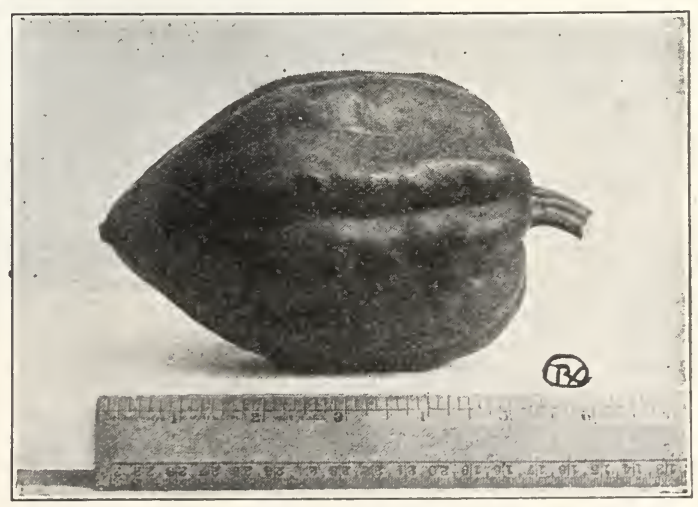

Table Queen 


\section{SELECTED TOMATO SEED \\ Northern Grown--Free From Blight--Matures Early}

We have had so many requests from our customers for better strains of Pepper and Tomato seed than is usually sold commercially, that we have endeavored to work up stocks, that, in our opinion, are far superior to the regular commercial seed generally sold. This, you realize, meant considerable work and the expenditure of a lot of money, but we feel that we have accomplished what we went after, and can now offer "With Pride," to our thousands of customers, the following Special Stocks, which we consider superior in every way to the regular or commercial seed.

They were all grown from Specially Selected Stock Seed and were thoroughly rogued of any plants showing off-type fruit before any seed was harvested. This entailed extra labor and expense and naturally makes the seed cost more.

EARLIANA-The Earliest Tomato in the world-by far the earliest, smoothest, solidest, most productive and best of all early tomatoes; resists wilt and other tomato diseases better than most others. This extreme earliness means millions of dollars to American Tomato growers. Fruit is bright crimson, thick, solid, heavy, smooth, firm, medium to large in size, superior quality, unusually heavy and continuous bearer throughout the season; best keeper and shipper.
JOHN BAER-An early variety, maturing with Bonny Best, producing fruit equally as good as Chalk's Jewel. Color, bright scarlet; good size and smooth. The seed we offer was grown from the introducer's stock.

Tomatoes grow splendidly trained to stakes or trellises. The fruit is much improved, not only in appearance, but in auality, and is a week or more ear'ier. This mode of cultivation is quite rommon an ong gardeners who grow for early market.

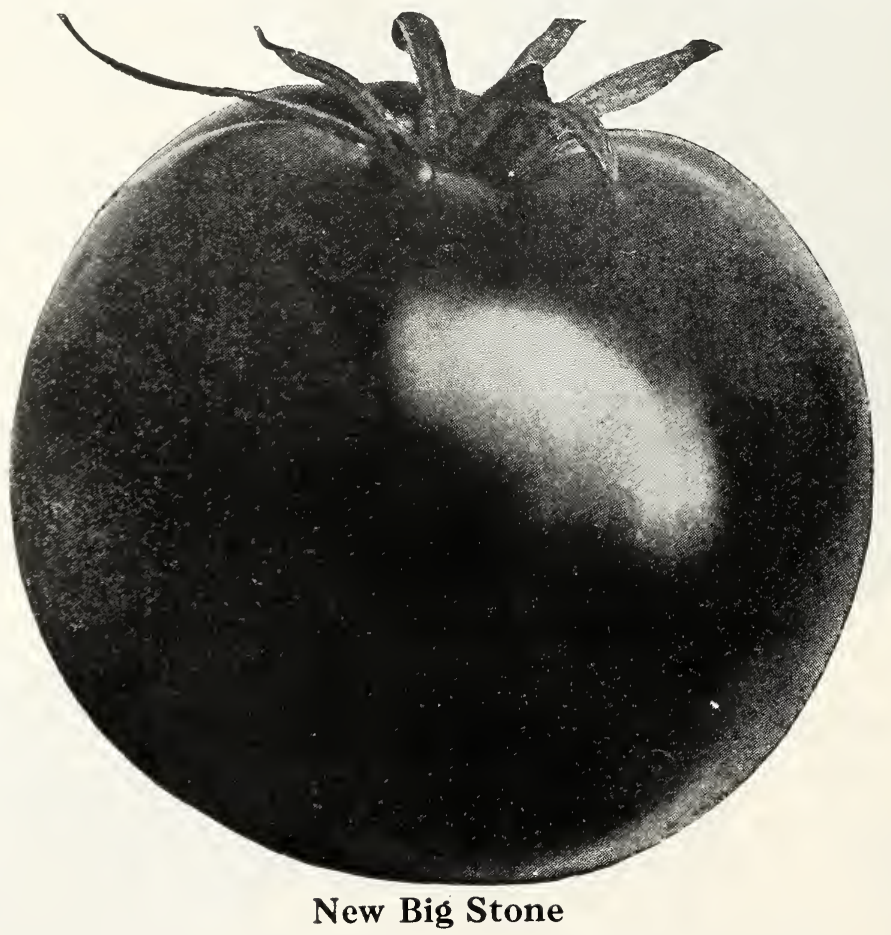

NEW TOMATO "AVON" - A red tomato equally as early as Earliana and a much larger and heavier yielder. The fruits are large, round or slightly flattened, deep scarlet-red color, smooth, free from cracks and of best eating quality. A good sort for market and early home garden use.
BONNY BEST - One of the finest bright red sorts for growing in greenhouses, and a good one to follow Earliana in the open field. Bonny Best is a favorite tomato of medium size. They are of bright scarlet color, always smooth, and of remarkably uniform size and shape A splendid sort for market and shipping. 


\section{SELEGTED TOMATO SEED}

LIVINGSTON'S GIOBE-'Tlis tomato has become a leader with prominent and successful tomato growers. In shape it is distinct, being globe-shaped, which permits a greater number of slices to be made. Of large size, smooth, firm and has very few seeds. Color a glossy pink, tinged with purple. Bears fruit in clusters of from three to seven; ready to pick in 95 days. Of special value to all long distance shippers or for forcing under glass. An excellent home gardener or market sort.

BEAUTY - Is the most popular of the Large Purple sorts. Vines large, vigorous and heavy bearers; fruit large, uniform, very smooth, purplish skin; flesh light pink, excellent flavor.

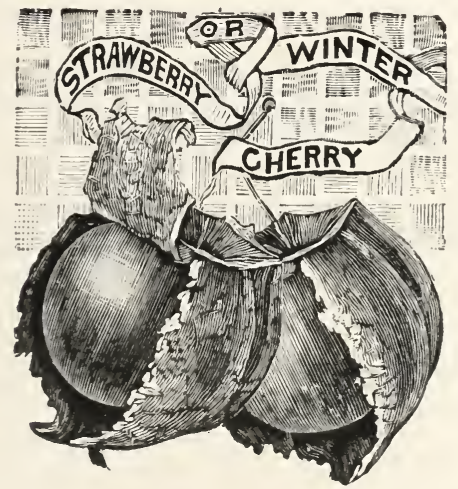

\begin{tabular}{|c|c|c|}
\hline TOMATO & $1-\mathrm{oz}$ & 4-oz. \\
\hline Earliana.. & .40 & 1.25 \\
\hline Bonny Best.. & .40 & 1.25 \\
\hline John Baer. & .50 & 1.50 \\
\hline New Avon. & .60 & 2.00 \\
\hline Livingston Globe. & .60 & 2.00 \\
\hline Beauty ...................... & .35 & 1.25 \\
\hline Marglobe.... ........ & .75 & 2.50 \\
\hline Dwarf Stone.... & .45 & 1.50 \\
\hline Panderosa $\ldots \ldots \ldots$ & .60 & 2.00 \\
\hline Golden Queen. & .40 & 1.25 \\
\hline New Big Stone.. & .40 & 1.25 \\
\hline Yellow Plum...... & .40 & 1.50 \\
\hline Yellow Husk or Ground Cherry & .50 & 1.50 \\
\hline Dwarf Champion & .45 & 1.50 \\
\hline
\end{tabular}

TOMATO, MARGLOBE-This great new tomato introduced by the U.S. Dept. of Agriculture through the efforts of Dr. Fred J. Pritchard, of the Bureau of Plant Industry, is the last word in tomatoes. Never before has hybrid of such great promise been brought to our notice. Its fine appearance, great productiveness, deep globe-shape and superb table qualities is giving it first place wherever known. Its spreading habits of growth enable it to bear large, perfect globe-shaped fruit in great abundance. In color it is a most beautiful scarlet, ripening well up to the stem.

DWARF STONE-Vine dwarf, vigorous and productive. While maturing with the later sorts the bright red fruit is of good color, exceedingly smooth, very solid and the largest of any of the dwarf varieties.

DWARF CHAMPION-An early purple-fruited variety, forming strong, ereet, bushy plants. Fruit medium size, smooth and fairly sold. Grown extensively for plants, as it makes a handsome, sturdy bush.

NEW BIG STONE-The very best of the main crop varieties. For yield, size and appearance, we have seen no finer strain than ours. The smooth skin, small core, fine-grained flesh with little acidity, delight the eater and give satisfaction to the grower, and marketgardeners find it their most profitable sort.

PONDEROSA - Largest of all tomatoes. Single specinens often grow to weigh from one and one-half to two pounds. Good flavor.

GOLDEN QUEEN-A handsome vellow variety of medium size and excellent flavor. Very attractive when sliced with the red sorts.

YELLOW PLUM-Fruits plum-shaped, of clear, deep yellow color; flesh yellow and finely flavored; esteemed for preserves.

YELLOW HUSK OR GROUND CHERRY - U'sed for preserving and eating from the hand. The seed we offer is that of the true Yellow Ground Cherry, not the purple-fruited sort which is scarcely edible. Excellent for making pies. 


\section{GARDEN TURNIPS}

EXTRA EARLY WHITE MILAN-The earliest white turnip, flat in shape and clear white throughout. Very tender; it is fit for use at least a week earlier than other turnips.

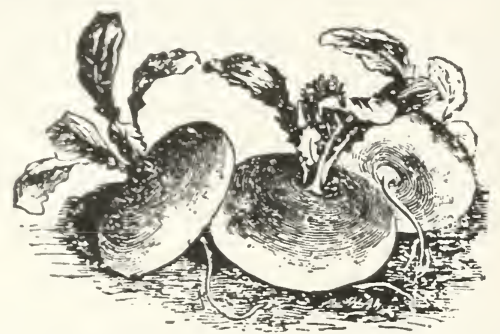

PURPLE TOP WHITE GLOBE-An early variety; globe-shaped; heary cropper; in other respects similar to the Red Top Strap Leaf. A handsome looking bulb, and is rapidly taking the lead of all other varieties of early turnips for market garden purposes.

WHITE EGG-A very early snow-white variety. The oval roots are of medium size and particularly smooth, and will not crack as readily as the flat varieties. The flesh is firm and fine-grained and particularly desirable for table use.

SNOWBALL, EARLY - Quick-growing, round, pure white and early, with medium-sized, smooth, and sweetly flavored roots, and short, scant top. Flesh pure white, fine-grained, and tender.

\section{KOHL RABI}

EARLY WHITE VIENNA-A short leaved, early variety that is of much finer quality than the Large White. The roots are best used when they are only two or two and a half inches in diameter.

\section{LEEK}

LARGE AMERICAN FLAG-The most popular variety; grows to a good size, and is straight and uniform, and is of the best quality.

\section{GARLIC}

Garlic is much esteemed for flavoring soups, stews' etc. The root or bulb is composed of many small bulbs called "cloves" which are planted in the spring. Easily grown anywhere.

\section{SALSIFY OR OYSTER PLANT}

MAMMOTH SANDWICH ISLAND-This splendid variety will average nearly twice the size of the White French Salsify. Grows very uniform. Mild and delicious in flavor. A popular sort with all growers.

\section{AROMATIC AND SWEET HERBS}

DILL-An annual. The seeds have an aromatic odor and warm pungent taste. They are used for seasoning and possess medicinal properties, but their largest use is for making dill pickles.

MARJORAM SWEET-Leaves and ends of the shoots are used for flavoring, both green and dried.

SAGE - Leaves and tops are used for seasoning and stuffing, also for medicinal purposes.

SUMMER SAVORY-Leaves and young shoots are used for flavoring, especially for boiled string beans.

THYME-Used for seasoning; a tea is also made for nervous headache.

\section{TURNIPS}

1-oz. 4-oz. 1-1b.

Extra Early White Milan..\$0.10 $\$ \mathbf{\$ 0 . 3 0} \quad \$ 1.00$

$\begin{array}{llll}\text { Purple Top White Globe.. } & \mathbf{1 0} & \mathbf{3 0} & \mathbf{1 . 0 0}\end{array}$

$\begin{array}{llll}\text { White Egg ............................. } & .10 & .25 & .75\end{array}$

Snowball, Early ..................... $\quad .10 \quad .25 \quad .75$

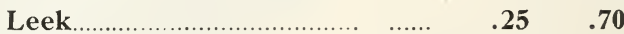

Kohl Rabi, Early
White Vienna ….......
.25 $\quad .75 \quad 2.50$

Garlic ....................................... $\quad .35$

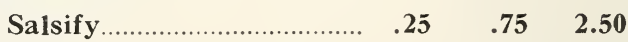

$\begin{array}{lllll}\text { Dill .......................................... } & .10 & .25 & .75\end{array}$

$\begin{array}{lll}\text { Sweet Marjoram ................. } & .25 & .75\end{array}$

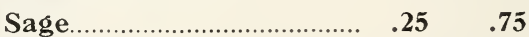

Summer Savory ................... $\quad .20 \quad .50$

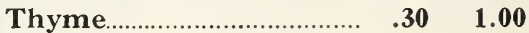




\section{HIGH GRADE FARM SEEDS}

\section{Prices on all Farm Seeds are subject to Market Changes}

ALFALFA GRIMM'S-The best of the alfalfas and recommended very highly. The price of this is usually high but it repays you. Resists the hard winters and is a heavy produrer.

ALFALFA-MONTANA-An excellent grade and quite hardy, being well adapted to the Northwest.

MEDIUM RED CLOVER - This is the reeognized standard of the clover family. It produces two crops each year. The first is generally harvested for hay when in full bloom. The second crop may be harvested for seed, cut for hay, or plowed under for fertilizer.

MAMMOTH RED CLOVER-This variety is grown mostly for pasture and for soiling. It is a very vigorous grower, but is not desirable for hay unless cut when quite young.

ALSIKE CLOVER - Grows well on low, wet land where Red Clover does not thrive. For heavy or wet land it is a good plan to mix Alsike and Red Clover, using about half of each. Alsike being a perennial will last for a good many years, either for hay or in pasture. It makes fine hay of high feeding value. It is very valuable in pastures, especially on wet or heavy soil.

WHITE BLOSSOM SWEE'T CLOVER-This variety is most generally referred to when sweet clover is mentioned. It lives for two years only, but will reseed itself if allowed to mature. Sweet clover will grow well on most any kind of soil, and will improve the soil for future crops.

WHITE OR DUTCH CLOVER-A low close growing clover, with round white heads. Very fragrant and desirable for beautifying the lawn. It will stand

\begin{tabular}{|c|c|c|}
\hline \multicolumn{3}{|c|}{ NORTHLAND BRAND } \\
\hline & Per lb. & $100 \mathrm{lbs}$. \\
\hline Alfalfa, Grimm's &..$\$ 0.30$ & $\$ 28.50$ \\
\hline Alfalfa, Montana & .22 & 21.00 \\
\hline Clover, Medium Red... & .24 & 22.00 \\
\hline Clover, Mammoth Red. & .25 & 23.00 \\
\hline Clover, Alsike & .21 & 20.00 \\
\hline Clover, Sweet White Blossom & .10 & 8.50 \\
\hline Clover, White or Dutch & .50 & 48.00 \\
\hline Timothy & .07 & 6.00 \\
\hline Red Top .... & .15 & 14.00 \\
\hline Kentucky Blue Grass &. .23 & 21.00 \\
\hline
\end{tabular}

close cutting and very rapidly throws up an abundance of leaves and blossoms. It is usually better to sow with other grasses. Does well on most any soil.

TIMO'THY - This crop is cut for hay; probably surpasses any other grass in cultivation; it thrives best on moist, loamy soils, and is not well suited to light, sandy or gravelly soils, it should be cut just when the blossom falls. Sow either in spring or fall, at the rate of $12 \mathrm{lbs}$. per acre, if alone, but less if mixed with other grasses.

RED TOP -Valuable for most soils. Good permanent grass; stands our climate well; is adapted to our pastures; has succeeded on alkali soil when other grasses failed. Fancy clean or hulled seed; sow 8 to 10 lbs. per acre.

KENTUCKY BLUE'GRASS-Will outlive any other grasses for pasture or lawn, but should not be cut or pastured too closely in extremely hot, dry weather. The seed is very slow in germinating, therefore, it is advisable to plant with other varieties of quicker growing habits. Makes a sweet and nutritious pasture for all stock.

APPROXIMATE AMOUN'T 'TO SOW PER ACRE AND WEIGHT PER BUSHEL

$\begin{array}{ll}\text { LBS. } & \text { LBS. } \\ \text { KIND } & \text { WEIGHT PER ACIR } \\ & \text { FER BU. TO SOW }\end{array}$

Alfalfa

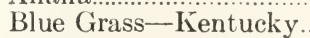

$60 \ldots \ldots \ldots \ldots .10-15$

Bromus Inermis

$14 \ldots \ldots \ldots .60-100$

Buckwheat.................................52 ..........50-60

Clover-Alike............................60.............6. 6 -7

Clover-Medium Red …..............60........... 8-12

Clover-Mammoth..........................60.............8-12

Clover-Sweet................................60...........12-15

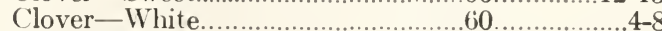

Corn-Hills................................56........... $7-14$

Corn-Fodder.............................56..........40-60

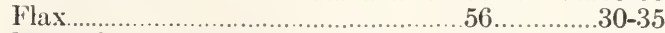

Lawn Grass....................................20..........60-100

Millet-For Hay .............................50............35-50

Peas-Canada Field.......................60........120-150

Rape-Dwarf Essex......................50.............5-7

Red Top-Solid Seed.....................42 ...........6-10

Rye........................................................... $70-75$

Sorghum-For Fodder...................50 ..........15-20

Sudan Grass..................................40 ............. 8-10

Soy Beans......................................60............. $30-45$

Timothy........................................................ 11-15 


\section{GRASS SEED}

SUDAN GRASS - The Hay Maker and Drought Resister Sudan is an annual grass and must be reseeded every year. The plant under favorable weather conditions grows to a height of 6 to 10 feet, but when broadcasted thickly it grows only 3 to 5 feet high. It frequently produces 20 or more stalks to a plant. The stems are unbranched, seldom larger than a lead pencil and are covered with an abundance of leaves. Is easily cured, making hay of excellent quality; which is readily eaten by all kinds of stock without injury to them. Sow seed by drilling or broadcasting, using 10 to 15 pounds per acre.

MILLET, JAPANESE-This is one of the largest varieties of millet. It grows so strong that the stalks look like small corn fodder. Very large crops can be raised, nearly double that of common millet. The hay is relished by horses, cows and sheep Even when seed is allowed to ripen, the hay after the seed is threshed out is readily eaten by stock, there being no waste as in the case of corn stalks.

MILLET, GERMAN-A valuable annual hay and fodder crop, more productive and larger than Hungarian, but is later and not so quick growing. Height from 3 to 5 feet. 48 pounds per bushel.

\section{RAPE}

DWARF ESSEX - Rape is one of the surest crops for late pasturing. The leaf resembles the rutabaga very much, but will produce a heavier growth, that is relished by hogs, sheep and cattle. It may be sown as late as July 1st,and produce a very fine fall pasture.

\section{SOY BEANS}

EARLY BLACK-One of the best in our opinion for the Northern States, where a quick-growing variety is desired. Average height on good land is about three feet, requires from 100 to 115 days to mature. Its fine stem enables it to cure quickly, which is a point in its favor.

\section{SUNFLOWER}

MAMMOTH RUSSIAN-May be grown to great advantage in waste ground. An excellent and cheap food for fowls. All farmers should plant this, if only for feeding chickens. It is enormously productive of seed, as the heads sometimes measure 18 inches in diameter. Plant 4 quarts to acre.

\section{BUCKWHEAT}

JAPANESE-Will produce a larger growth and will stand dry weather better than any other variety. The kernel is large, dark brown and matures very early. As much as 40 bushels to the acre have been harvested of this variety, making it very profitable to raise.

COMMON FLAX-Is used to a great extent on entirely new soil with very good results. We take special care of securing seed that is entirely free from foul seeds.

\section{FIELD PEAS}

CANADA FIELD PEAS, YELLOW-This is a standard variety. It is used for stock feeding and forage. The peas are used for soups and poultry feeds.

GANADA FIELD PEAS, GREEN-Used for the same purposes as the yellow peas only a different color.

COW PEAS-These are grown chiefly as pasture for cattle, sheep and swine.

\begin{tabular}{|c|c|c|}
\hline 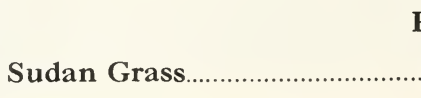 & $\begin{array}{c}\text { Per lb. } \\
\ldots \$ 0.10\end{array}$ & $\begin{array}{c}100 \text { lbs. } \\
\$ 9.00\end{array}$ \\
\hline Millet, Japanese & .... .06 & 5.00 \\
\hline Millet, German............... & $\ldots . .07$ & 6.00 \\
\hline Rape, Dwarf Essex.... & .... $\quad .10$ & 8.75 \\
\hline Soy Beans..................... & $\ldots . \quad .08$ & 7.00 \\
\hline Sunflower..................... & $\ldots . .15$ & 12.00 \\
\hline 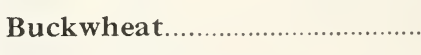 & $\ldots .05$ & 4.00 \\
\hline Field Peas, Yellow.............. & $\ldots . \quad .10$ & 8.50 \\
\hline Field Peas, Green & $\ldots .10$ & 8.50 \\
\hline Flax & ..Bushel & 4.00 \\
\hline
\end{tabular}


FIELD CORN

\section{The Best for the Northwest}

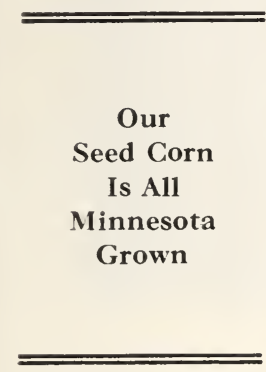

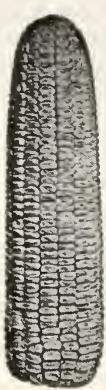

Rustler

White
Dent

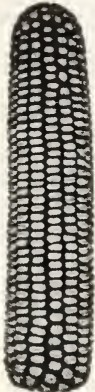

Lindholm's Early

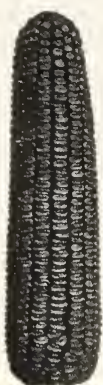

Minn.

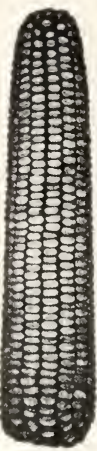

N. $W^{r}$. Dent
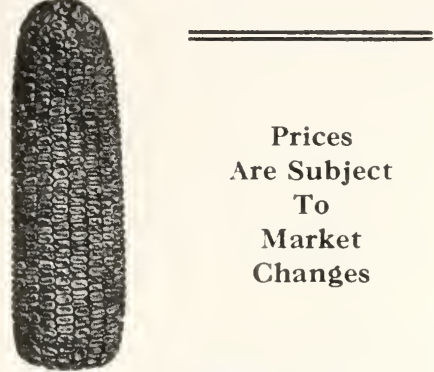

Prices

Are Subject

To

Market

Changes
MINNESOTA No. 13-Is so well known that it is unnecessary to devote any space to its description. It is the standard Yellow Dent for Minnesota, produces a nice uniform ear of fairly good size, and maturing about Sept. 1st.

RUSTLER'S WHITE DENT-This early White Dent corn is one of the best for early ripening in any of our Northern States. The ears are large, having from 14 to 18 rows of well shaped deep kernels. The average height of the stalks is 8 feet.

LINDHOLM'S EARLY MINNESOTA - This corn you will find to be the earliest of all dent corns and matures in Minnesota in 80 days, and ripens in this northern latitude if planted as late as the first of June. It will do well on either clay or black soil land. Every gardener should not fail to plant a few acres of this variety to insure against crop failure. Grain has white cap and yellow body. Stalks have plenty of blade, making excellent fodder.

TRIUMPH-This corn is the largest early and most productive of all the early flint varieties. The stalks grow very tall and leafy and make superior fodder. Ears average from 14 to 16 and sometimes as high as 20 rows. This corn is early enough to escape destructive frosts.

\begin{tabular}{|c|c|c|}
\hline \multicolumn{3}{|l|}{ FIELD CORN } \\
\hline & Peck & Bus. \\
\hline Minnesota No. $13 \ldots \ldots$. & $\$ 1.15$ & $\$ 4.00$ \\
\hline Rustler's White Dent & 1.15 & 4.00 \\
\hline Early Minnesota.. & 1.15 & 4.00 \\
\hline Triumph. & 1.35 & 5.00 \\
\hline Early Murdock. & 1.35 & 5.00 \\
\hline Northwestern Dent & 1.35 & 5.00 \\
\hline Minnesota Ideal. & 1.35 & 5.00 \\
\hline POP GORN & 1-1b. & 5 lbs. \\
\hline White Rice........................ & $\$ 0.20$ & $\$ .90$ \\
\hline Japanese Rice...... & .20 & .90 \\
\hline Black Beauty..... & .20 & .90 \\
\hline Red Beauty..... & .25 & 1.00 \\
\hline South American (new) & .25 & 1.10 \\
\hline
\end{tabular}

NORTHWESTERN DENT - This is the earliest Dent Corn for the Northwest; that is, for most parts of North Dakota, Northern Minnesota, Northern Wisconsin, etc., where hardly any other variety can be depended upon to mature. It is a cross between a red flint and yellow dent corn, and has red kernels with yellowish and white cap and shadings. Under ordinary conditions it will mature from in 85 to 90 days, and will yield from sixty to eighty bushels to the acre. The ears are of good size, from seven to ten inches long, bearing ten to fourteen rows.

MINNESOTA IDEAL-One of the largest yielders of the Yellow Dent type, that will mature in this locality. Although not as early as Minnesota 13, or Gould's Reliable, it will as a rule mature in good season.

\section{POP CORN}

Very often it is overlooked that Pop Corn is one of our most profitable crops. It yields exceptionally well even under unfavorable conditions and there is invariably a demand for the seed. This demand is created by the Corn that is sold annually for popping purposes and for the making of cracker jack and like confections.

WHITE RICE-This is the most popular of the pop corn family. The kernels are white and pointed, popping to a pure snow white.

JAPANESE DWARF RICE-Very tender and almost hulless. Ears are short and cliunky. Although the kernels are very small they pop to a large size, being very tender and brittle.

BLACK BEAUTY - A very early variety of a blueblack color. The kernels are large and smooth, popping to a very large size, and becoming very crisp and tender.

SOUTH AMERICAN (NEW)-Also known as Dynamite, T. N. T. and Mushroom. Produces yellow kernels much larger than other varieties. Pops to enormous size; flavor excellent. We recommend the use of this instead of Queen's Golden and other similar sorts. Ears are long and slender. Fourteen rowed. 


\section{FODDER CORN}

GIANT FODDER CORN-This is a very tall growing leafy variety of southern white corn. A very heavy yielder, often producing from 10 to 25 tons of green feed per acre.

We recommend sowing this corn very thick in order to prevent stocks from becoming too large and coarse. From one to two bushels per acre by drills may be sown with very good results.

ELEPHANT FODDER - Of the yellow dent type, but grows taller and more leafy than the average yellow dent corn, therefore producing a very heavy yield.

RED COB FODDER - Is a tall growing southern corn that will produce an abundance of feed per acre. The kernel is white and grows on a red cob, thus deriving its name.

ACME FODDER CORN-The Best Silage Corn for the Northwest-Acme Fodder is a mixture of off type dent corn or of the local mixed strains or other early dents of which we may have an extra amount. Being a mixture it is ranker and more luxuriant in growth and a heavier producer. For this reason it is especially valuable for silage. It is easily handled with a binder and gives just about the right degree of maturity early enough for silo filling.

EVERGREEN SWEET CORN FOR FODDERSweet corn makes the finest kind of fodder and it is rich in sugar and so tender that cattle eat it up clean. There is no corn that produces such excellent fodder. There is little or no waste in feeding it and the crop produced is as large as from field corn which makes fodder of much inferior quality. The seed we offer is genuine Evergreen Sweet Corn and is of good strong germination.

\section{SUGAR CANE OR SORGHUM}

Our customers are constantly increasing their sowings of this cheap and exceedingly useful summer fodder for all stock and especially milch cows. Every farmer, sinall or large, should make sowings of it.

\section{Vegetable Plants and Roots}

\section{RHUBARB ROOTS}

People are just beginning to realize the great profit in the culture of Rhubarb in the open field, also as a forcing crop for winter. It yields enormous profits. Anyone can succeed, as the culture is very simple. The roots we offer are division of large roots. $10 \mathrm{c}$ each; 85c doz.; $\$ 6.00$ per 100.

\section{VEGETABLE PLANTS}

Cabbage Early and Late varieties-doz. 10c; $100,70 \mathrm{c}$.

Cauliflower, Snowball-doz., 25c; 100, \$2.00.

Celery, Golden self-blanching-doz., 20c; $100, \$ 1.25$.

Chives, May 1st-bunch, 10c; doz., \$1.00

Egg Plant, June 1st-doz. 40c.

Ground Cherry or Husk 'Tomato-doz., 25c; $100, \$ 1.50$.

Pepper-doz., 40c; 100, $\$ 2.00$.

Tomato, Early and Late varieties-doz., 35c; $100, \$ 2.00$.

\section{ASPARAGUS ROOTS}

We have some really fine, large, strong 2-year-old roots of our own growing. If 2-year-old roots are set out this spring shoots can be cut next spring, but cutting should not continue more than 10 days or two weeks. 2-years old; good, strong, well-grown roots-doz., 30c; $100 . \$ 1.25 ; 1,000, \$ 10.00$.

\section{FLOWERING PLANTS}

Asters, mixed colors-doz., 25c.

Colus, green, red and variegated-each, 10c; doz., 75c.

Canna, King Humbert, red leaved-each, 25c; doz., \$2.50.

Geraniums, red, white, pink,-each, 25c; doz., $\$ 2.50$.

Pansies, mixed colors-doz. 35c.

Petunias, single and double-each, 15c; doz. $\$ 1.50$.

Salvia, in pots, - each, 10c; doz., \$1.00.

Vincas, green and variegated-ea., 20c; doz., 2.00

\begin{tabular}{|lrc|}
\hline \multicolumn{1}{|c|}{ FODDER CORN } & Per Bushel \\
Giant Fodder Corn $\ldots \ldots \ldots \ldots \ldots \ldots \ldots \ldots \ldots$ & $\$ 2.15$ \\
Elephant Fodder Corn $\ldots \ldots \ldots \ldots \ldots \ldots \ldots$ & 2.15 \\
Red Cob Fodder Corn $\ldots \ldots \ldots \ldots \ldots \ldots \ldots \ldots$ & 2.15 \\
Acme Fodder Corn $\ldots \ldots \ldots \ldots \ldots \ldots \ldots \ldots \ldots$ & 2.15 \\
Evergreen Sweet Corn for Fodder.... & $\mathbf{1 0 . 0 0}$ \\
Sugar Cane or Sorghum $-1001 \mathrm{lbs} . \ldots$. & $\mathbf{6 . 0 0}$ \\
\hline
\end{tabular}




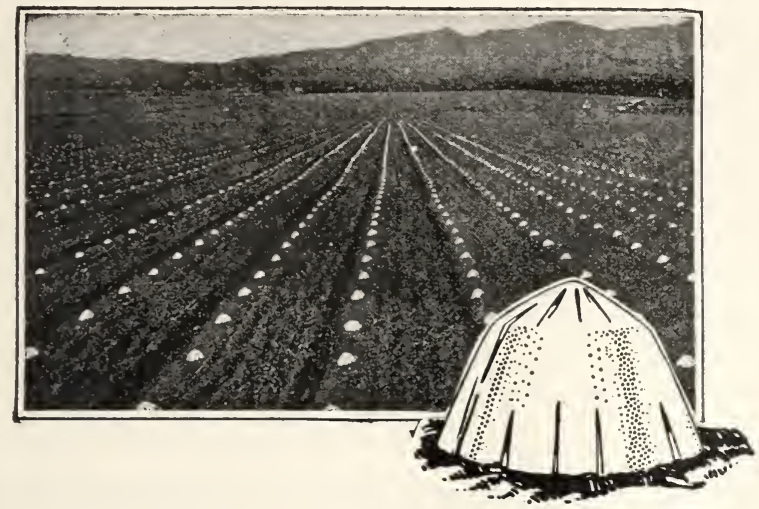

\section{Higher Prices for Your Crop}

\section{. . THIS AMAZING NEW METHOD OF PLANT PROTECTION GETS YOU HIGHER PRICES FOR LARGER AND QUICKER CROPS}

Last year thousands of growers added to the value of their vine crops by using Germaco HOTKAPS - shown above. This remarkable invention consists of a scientifically constructed wax paper cone that you place over each plant. Thus they are miniature hot-houses that protect plants from frost, wind, rain, insects and ground crusting.
HOTKAPS not only protect plants, but make them grow hardier and faster. Thus you get a greater crop production to market earlier for higher prices!

You can add to your next year's profit with HOTKAPS They cost but a fraction over a penny each. One man can "set" 3,000 HOTKAPS per day. They not only bring you higher prices but are a method of crop insurance-against the danger of the elements.

Prices: 1,000 lots, $\$ 11.50$; 5,000 lots, $\$ 11.00 ; 10,000$ lots, $\$ 10.75$. 250 trial package, including special type garden setter, $\$ 4.00$; standard Germaco HOTKAP setter, $\$ 2.50$.

If you need HOTKAPS for your backyard garden, note these prices: 50 with garden setter, $\$ 1.50 ; 100$ with garden setter, $\$ 2.25$; garden setter alone, 50 cents.

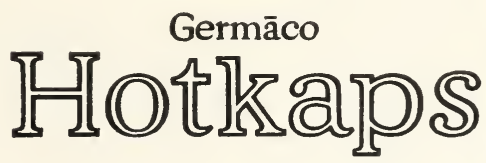




\section{Fertilizers}

\section{NITRATE OF SODA}

A fertilizer very quick in action and used for the nitrogen it contains. It creates rapid growth, is odorless, very quickly and entirely soluble. It should be applied only when the plants are above ground. Nitrate of soda is the best form in which nitrogen can be returned to the soil. It is of special value for early crops such as Peas, Corn, Beets, Cabbage, etc., when rapid maturity is essential, and of great benefit to hay and forage crops. Nitrate of Soda is a great stimulant for the production of Sugar Beets, Potatoes and Sorghum, also small fruits.

Use as a top dressing at the rate of $100 \mathrm{lbs}$. per acre on the following vegetables when plants are well established, viz.: Beet, Cabbage, Cauliflower, Cucumber, Celery, Egg Plant, Lettuce, Spinach and Onion.

For Asparagus use at the rate of $250 \mathrm{lbs}$. per acre as a top dressing after the first shoots make their appearance.

For Strawberries use 100 lbs. per acre as a top dressing after the plants have blossomed.

For Grass and Grain use at the rate of $100 \mathrm{lbs}$. to $200 \mathrm{lbs}$. per acre when growth is well established.

For the home garden, apply in soluble form, using one ounce to 2 gallons of water.

Nitrate of Soda should be applied directly to the soil and should not be allowed to touch the foliage.

We handle the Empire Brands of the American Agricultural Chemical Company. This fertilizer has proven to given entire satisfaction.

\section{PULVERIZED SHEEP MANURE}

This pure natural manure is immediately effective, unequalled for mixing with the soil. Excellent for the flower or vegetable garden, potted plants, lawn, outdoor plants, shrubbery and small fruits.

Flower and Vegetable Garden-Plow or spade up the ground about 6 or 8 inches deep. Scatter the sheep manure over the entire surface. Work thoroughly into the soil by harrowing or raking.

Potted Plants-Apply it dry and work it into the top soil using one tablespoonful to a 6 or 8 inch pot; use every 3 or 4 weeks. Repotting plants, mix thoroughly one part sheep mature to five parts soil.

Old Lawns-Scatter the sheep manure over the entire surface, in early spring or fall, but be sure to keep the ground moist for a few days.

New Lawns-The soil should be plowed or spaded to a depth of 6 to 8 inches. Scatter the sheep manure over the entire surface. Harrow or rake in thoroughly and level the soil as desired. Sprinkle well with water and let stand 24 hours before seeding.

Outdoor Plants, Shrubbery and Small Fruits -Loosen the soil around the plants. Scatter the sheep manure over the entire surface. Work thoroughly into the soil.

Liquid Manure-Mix $1 \mathrm{lb}$. sheep manure to 5 gallons of water, applying the mixture direct to the soil; repeat once a week until the plant shows healthy growth, then apply once a month.

\begin{tabular}{|lrrc|}
\hline & 25 lbs. & 50 lbs. & 100 lbs. \\
Nitrate of Soda ........ & $\$ 1.50$ & $\$ 2.50$ & $\$ 4.50$ \\
Sheep Manure $\ldots . . . .$. & .75 & 1.40 & 2.25 \\
\hline
\end{tabular}




\section{General List of Reliable Flower Seed}

\section{ASTERS}

QUEEN OF THE MARKET-These well known, early flowering Asters are of a branching habit, about 18 inches high, coming into bloom directly after the early Express, and are one of the most useful types for early market purposes.

We have them in the following colors: Crimson, Dark Blue, Flesh Pink, Lavender Rose, White and Finest Mixed.

Oz., \$1.00; Pkt., 5c

ROYAL-These are dwarf, branching, about two feet high. Flowers of the branching class, coming into bloom directly following the Queen of the Market. Lavender, Violet, Rose, Purple, Deep Shell Pink, White and Finest Mixed.

Oz., $\$ 1.00 ;$ Pkt., $5 c$

AMERICAN BRANCHING-Plants $21 / 2$ to 3 feet high, branching and robust habit. Flower large and double, throwing no single flowers. Blue, Crimson, Lavender, Deep Rose, Shell Pink, White, and Finest Mixed.

Oz., \$1.00; Pkt., 5c

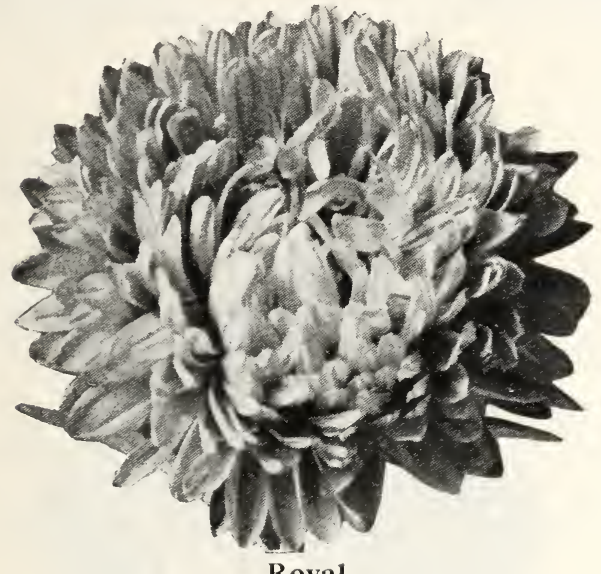

Royal

ACHILleA, The Peari-Double white perennial. Pkt., 10c

ACROCLINEUM ROSEUM-Mixed everlasting. $\mathrm{Oz}, 50 \mathrm{c} ;$ Pkt., $5 \mathrm{c}$

ACONITUM NAPELLUS-Blue monkshood perennial. Oz., 50c; Pkt., $5 \mathrm{c}$

AGERATUM-Blue Perfection. This the darkest color. $\mathrm{Oz}$, 50c; Pkt., $5 \mathrm{c}$

ALYSSUM-Little Gem, or Carpet of Snow.

Oz., 50c; Pkt., $5 c$

ANTIRRHINUM-New type of Snapdragon with very large flowers in many beautiful shades; semitall. Now largely used for cutting both sumner and winter, also very 1 opular for bedding.

Oz., 50c; Pkt., $5 \mathrm{c}$

AQUILEGIA (Columbine)-Perennial. This beautiful plant thrives in all kinds of soil; flowers abundantly from early May until last of June; varied colors.

Oz., 60c; Pkt., $5 \mathrm{c}$
BALSAM (Lady Slipper)-Double Camelia Flowered Mixed.

Oz., 50c; Pkt., 5c

BELLIS PERENNIS-(English Daisy) Mixed.

Oz., \$3.00; Pkt., 5c

CALENDULA ORANGE KING-Special florists' strain selected.

Oz., 50c; Pkt., 5c

CALLIOPSIS-Dwarf mixed, dainty yellow and brown.

Oz., 50c; Pkt., 5c

CANDYTUFT (Giant Empress)-An improved variety, producing very long spikes of bloom resembling a white hyacinth.

Oz., 40c; Pkt., 5c

CARDINAL CLIMBER-One of the best annual climbers introduced.

Oz., \$1.00; Pkt., 10c

GELOSIA CRISTATA NANA-Mixed Cockscomb, Dwarf.

Oz., \$1.75; Pkt., 10c

CELOSIA PLUMOSA-Feathered varieties in all colors; mixed.

Oz., 50c; Pkt., 5c

CENTAUREA (Bachelors' Buttons)-It is not a pretentious plant but will always charm by its simple beauty.

Oz., 40c; Pkt., 5c

CARNATION-Marguerite come into flower early in summer, supplying a good crop of flowers for cutting up to frost.

Oz., \$2.00; Pkt., 10c

CLARKIA-Charming annuals for flower beds, with colors, white rose, red, purple, etc.,

Oz., 50c; Pkt., 5c

COSMOS-Early flowering; mixed.

Oz., 40c; Pkr., 5c

NEW EARLY DOUBLE GRESTED COSMOS.

Oz., \$3.50; Pkt., 10c

GHRYSANTHEMUM-New large flowered double and semi-double hybrids. By seeding early they will bloom in July and August. Oz., 50c; Pkt., 5c

COREOPSIS GRANDIFLORA-Yellow perennial. Oz., 75c; Pkt., 5c

CONVOLUVLUS-(Morning Glory)-Najor; all colors mixed.

Oz., 25c; Pkt., 5c

DELPHINIUM (Hardy Perennial Larkspur)The Delphiniums are one of the most popular perennials and are in great demand both for garden decoration and for cutting.

BELLA DONNA - This is the beautiful light blue Delphinium so universally admired. The flowers which are distributed so gracefully along the tall stems, are a very pretty shade of clear turquoiseblue.

Oz., \$2.50; Pkt., 15c

FORMOSUM - We are fortunate in having secured a fair crop of this fine, deep blue with white centre. Oz., \$3.00; Pkt., 15c

BELLAMOSUM - This is a dark blue form of the popular light blue Belladonna, with which it is identical in habit of growth, freedom of bloom and other good qualities, but with intensely rich deep blue flowers. 


\section{GENERAL LIST OF RELIABLE FLOWER SEED}

DELPHINIUM (Hardy Larkspur)-The new indigo blue is the best Delphinium we ever saw; it is almost variegated; purple and blue; and stands the hot weather better than any other kind.

Oz., \$3.50; Pkt., 20c

GOLD MEDAL HYBRIDS- Unquestionably the finest strain of mixed hybrids offered. The original stock came from England, and consisted of the bestnamed varieties.

Oz. \$1.50; Pkt., 10c

VANDERBILT HYBRIDS - A Californian novelty of charming beauty. Immense flower stalks with great heads of bloom tapering to the tip. Nearly all flowers open at once and exhibit the greatest combination of colors known. Oz., \$2.50; Pkt., 20c

DIANTHUS-(Double Flowering Annual Pinks) - There are few annual flowers that will produce such a brilliant display of color for so long a time as the various varieties of dianthus. $\mathrm{Oz} ., \$ 1.00 ; \mathrm{Pkt} ., 5 \mathrm{c}$

DOLICHOS (Hyacinth Bean)-A very rapidgrowing, hardy annual climber, bearing pea-shaped blossoms and ornamental seed pods. Fine for covering screens.

$\mathrm{Oz} ., 20 \mathrm{c}$; Pkt., 5c

ESCHSCHOLTZIA (California Poppy)-This beautiful and brilliant annual has been greatly im. proved in recent years, and we now have many beautiful and unusual colors.

Oz., 50c; Pkt., 5c

EUPHORBIA (Variegata, Snow of the Mountain) - Attractive foliage, veined and margined with white; 2 feet.

Oz., 60c; Pkt., 5c

GAILLARDIA (Annual Varieties)-They will produce from early spring until late fall a continuous profusion of brilliancy colored flowers; red and yellow.

$\mathrm{Oz} ., 50 \mathrm{c} ;$ Pkt., 5c

GRANDIFLORA SUPERB MIXED (Hardy Perennial Varieties) - Our own saving; splendid combinations of crimson and gold in great variety.

Oz., 60c; Pkt., 5c

NEW HYBRIDS - Very large flowers, in a great variety of colors.

Oz., \$1.00; Pkt., 10c

EUPHORBIA HETERAPHYLLA (-Mexican Fire Plant). Oz., 60c; Pkt., 5c FOUR O'CLOCK or MARVEL OF PERU. Oz., 20c; Pkt., 5c

FORGE'T-ME-NOT-(Victoria, Blue).

Oz. \$2.00; Pkt., 10c

GODETIA-Splendid hardy annuals with large mallow-like flowers.

$\mathrm{Oz} ., 50 \mathrm{c}$; Pkt., 5c

GLOBE AMARANTH-A desirable everlasting, valued for its handsome small, globular flower heads which, if cut when well matured, will retain their beauty through the winter.

Oz., 50c; Pkt., 5c

GOURDS - Many of these besides having interesting fruits are very ornamental when used as climbers. They easily attain a height of 15 feet.

$\mathrm{Oz} ., 25 \mathrm{c} ;$ Pkt., 5c
ANNUAL GYPSOPHILA (Baby's Breath)Graceful, free-flowering plant, forming a symmetrical bush, covered with loose panicles of flowers, excellent for cutting and mixing in bouquets.

ELEGANS DELICATE PINK-A pretty blush pink form of the above, and equally as valuable for cutting.

Oz., 30c; Pkt. 5,c

ELEGANS GRANDIFLORA ALBA-This is an improved large-flowering, pure white, of free, easy growth. Several sowings should be made during the season to keep up a supply. Oz., 30c; Pkt., 5c

GYPSOPHILA (Baby's Breath)-Perennials. The following are always in demand to mix with other cut flowers:

PANICULATA(Baby's Breath) - The fine, mistlike flowers are much used in bouquets. Oz., .60 Pkt.,.05

PANICULATA (fl. pl.)-Double flowering. The original type and one of the best perennials in the list for cutting. Oz., \$10.00; Pkt., .50

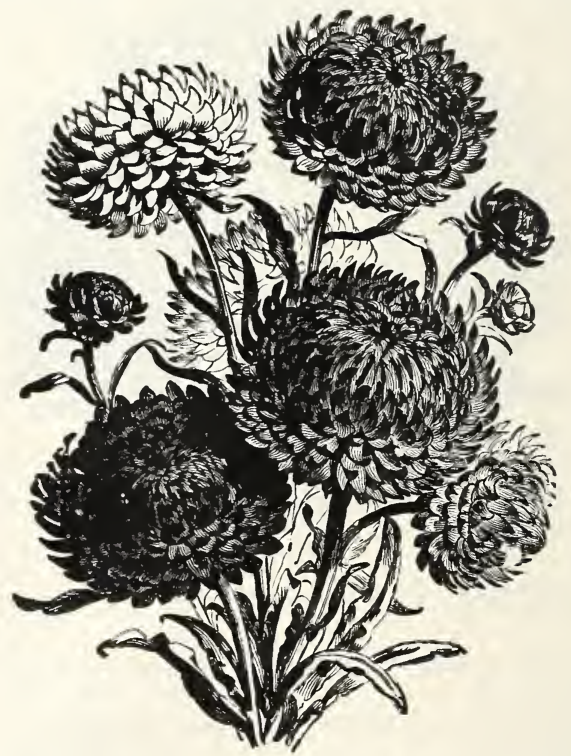

HELICHRYSUM (Straw Flower)-Monstrosum (f. pl.)-One of the best of "Everlastings." Exceedingly effective double flower in rich glittering colors, making a fine display in beds or borders, but especially grown to dry and use in baskets and vases through the winter; when wanted for this purpose they snould be cut with as long stems as possible, and when the blooms are about one third open, take off all foliage, tie in bunches and hang head downwards in some dark, dry place until cured; they succeed in any good garden soil. We offer the following choice colors: Fireball, Golden Ball, Rose, Silver Ball, Salmon and Mixed Colors.

Oz., 75c; Pkt., 5c 


\section{GENERAL LIST OF RELIABLE FLOWER SEED}

NEW DOUBLE HOLLYHOCKS-These are the finest Hollyhocks we have ever seen. 'The size of the great double blossoms and the majestic flowering stem crowded for three to four feet with the massive flowers make a wonderfully effective display.

Oz., \$1.50; Pkt., $10 c$

ANNUAL LARKSPURS-The annual Larkspurs are suitable for cutting and supply a large quantity of flowers all through the season.

$$
\text { Oz., 60c; Pkt., 5c }
$$

LOBELIA (Farquhar's Dark Blue)-The fines! dwarf blue Lobelia for berding. The plants are compact and covered with a profusion of flowers.

Oz., \$2.01; Pkt., 10c

ANNUAL LUPINUS-The annual Lupinus are now very popular as cut flowers.

$$
\text { Oz., 30c; Pkt., 5c }
$$

MARIGOLD-Both the African and French sorts are among the most popular annuals for bedding and cutting.

$$
\text { Oz., 60c; Pkt., 5c }
$$

DOUBLE AFRICAN MARIGOLDS-Splendid for beds or borders; the tall varieties grow about 3 feet high, the dwarf sorts 18 to 24 inches.

$$
\text { Oz., 60c; Pkt., 5c }
$$

FRENCH MARIGOLD-These are a dwarf compact plant very attractive, each being covered with hundreds of small bright flowers of various colors.

Or., 60c Pkt., 5c

MIGNONETTE-For florists' use we especially recommend the Red Goliath and Machet. But all of the varities offered are good and strictly select stock.

RED GOLIATH-We consider this the largest and best of the red varieties. Very choice stock.

$$
\text { Oz., \$1.00; Pkt., 5c }
$$

MACHET-Of dwarf pyramid growth, bearing numerous flower stalks, highly colored and very fragrant; one of the best.

$$
\text { Oz., \$1.00; Pkt., 5c }
$$

MORNING GLORY (Large Flowering)-The Convolvulys Major is an annual of rapid growth; large flowers of many colors; suitable for porches or arbors, blooming in July and constantly till frost.

Oz., 20c; Pkt., 5c

DWARF BEDDING NASTURTIUM-We offer these low-growing Nasturtiums in a special mixture of brilliant colors which, we believe, cannot be surpassed.

$$
\text { Oz., 10c; Pkt., 5c }
$$

NASTURTIUMS-We sell immense quantities of climbing nasturtiums. They are very effective in window boxes, vases, baskets, etc.

$$
\text { Oz.. 10c; Pkt., 5c }
$$

\section{LINDHOLM'S BEST STRAINS OF MIXED PANSY}

MASTERPIECE OR GIANT RUFFLED - These pansies are very large and the petals are frilled and ruffled to a greater extent than other kinds. The colors are excellent and the plants of great vigor, holding the immense flowers well up on long strong stems. The petals are often so large and fluted that the flowers appear to be double.

Oz., \$4.00; Pkt., 1Cc

\section{PETUNIAS}

Few annual plants equal in effectiveness the Petunia for growing in beds and borders or in window and porch boxes. They commence flowering early and continue a sheet of bloom until frost.

SINGLE BEDDING PETUNIA-Large single flowers, blotched and strined in all the Petunia colors; fine for bedding; blooms a few weeks after planting and continues to bloom profusely until frost; all colors mixed.

Oz., \$1.50; Pkt., 5c

BALCONY PETUNIAS-One of the handsomest porch boxes we have ever seen had Rosy Morn Petunias in the background and Balcony White along the front and drooping down from it. A valuable thing about Petunias for beds, bases or boxes is that they stay in bloom all season.
Balcony Rose
Oz., \$5.00; Pkt., 50c
Balcony White
Oz., \$4.50; Pkt., 50c
Balcony Blue.
Oz., \$8.00; Pkt., \$1.00

PHLOX DRUMMONDI GRANDIFLORA-This is the large flowering class, and in all its varieties of colors and shades cannot be excelled by any annual for brilliant and constant display. Blooms from July to November.

Oz., \$1.00; Pkt., 5c

PORTULACA (Moss Rose)-Will grow and bloom abundantly all summer in a dry, hot loration, where most other plants would soon die. The flowers are of the richest colors and make a beautiful border. Single mixed colors.

$$
\text { Oz., 80c; Pkt., 5c }
$$

DOUBLE FLOWERED (Finest Mixed Colors) Resembles beautiful double roses, though only one inch in diameter; several colors, very showy.

Oz., \$4.00; Pkt., 10c

\section{MIXED FLOWER SEEDS}

People who wish a great variety of flowers at small cost will do well to plant a packet of this seed. It is a mixture of different annuals, all the best sorts, and those which grow and bloom together in wild garden style.

Oz., 40c: Pl:t, 5c 


\section{GENERAL LIST OF RELIABLE FLOWER SEED \\ POPPIES \\ SWEET PEAS}

Plants are to remain as they will not bear transplanting. As cut flowers they are s'ort-lived, but if their stems are dipped in boiling water for just one moment when cutting they will last much longer.

RELIABIE DCUBLE MIXTURE-The flowering period of Double Poppies is very much longer than that of the Single Shirleys and the plants need more space to develop to perfection. Double Poppies make splendid cut flowers. Mixed colors.

$\mathrm{Oz} ., 60 \mathrm{c} ;$ Pkt., $5 \mathrm{c}$

SHIRLEY, OR SILK SINGLE POPPIESThese are by far the best of all single Poppies. They range in color from the purest white to the deepest crimson and blood-red. Oz., 60c; Pkt., 5c

PYRETHRUM-Single mixed, 2 feet; May and June; splendid for beds and borders; nothing is finer for cutting. Produces single daisy-like flowers of all colors, in great profusion. Oz., $\$ 2.00$; Pkt., 10c

RICINUS (Castor Bean)-Stately, strong-growing plants, with very ornamental foliage, well adapted as centre plants of groups of Cannas, Dahlias, etc.

Oz., 20c; Pkt., 5c

SALPIGLOSSIS-A very beautiful hardy annual plant, flowering freely from July to early autumn. Rich soil should be provided with plenty of space for plants to develop. $\quad \mathrm{Oz}$., \$1.50; Pkt., 5c

SCABIOSA (Mourning Bride)-Fine free-blooming plants for mixed borders and excellent for cutting. Flowers borne on long, erect stems, in globular heads in colors of nearly white to dark purple maroon.

Oz., 60c; Pkt., 5c

SALVIA, SCARLET SAGE-A standard bedding plant that keeps the garden bright with color until late in autumn. It is especially adapted for a border in front of tall shrubs or in back of dwarf growing plants.

$\mathrm{Oz} ., 75 c$; Pkt., 5c

SPLENDENS - Blooms from August until killed by frosts. $\quad$ Oz., \$2.00; Pkt., 15c

BONFIRE-The spikes grow erect and stand clear above the foliage. The plants form handsome globular bushes.

Oz., \$4.00; Pkt., 10c

STATICE-Very popular for table decorations and when carefully dried the flowers retain their coloring for a long time. It is better to start seed inside in flats or boxes.

Oz.,\$1.50; Pkt., 10c

TEN WEEKS' STOCK-Stocks are half-hardy annuals, beautiful and fragrant old-fashioned flowers. Sow under glass or on warm border early in Spring transplant to rich ground.

$\mathrm{Oz} ., \$ 2.00 ;$ Pkt., $10 \mathrm{c}$

SWEET WILLIAM-A well-known, attractive free-flowering plant hardy, bearing in the early summer rich and varied colors that make a splendid show in beds and borders.

Oz., \$2.00; Pkt., 10c

SHASTA DAISY - One of our most popular perennials that grows well and blooms abundantly in almost any situation.

Oz. \$2.00; Pkt., 10c
Everybody likes Sweet Peas, and they are grown with as little care, and bloom so profusely that the smallest garden should contain a good supply.

ECKFORD MIXTURE-This mixture contains the cream of the new and standard sorts.

Oz., 10c; Pkt., 5c

\section{GRANDIFLORA VARIETIES}

BLANCHE FERRY-Scarlet.

Oz., 20c; Pkt., 10c

DOROTHY ECKFORD-Pure white.

Oz., 20c; Pkt., 10c

LADY GRISEL IIAMILTON-Lavender.

Oz., 20c; Pkt., 10c

KING EDWARD VIII-Large carmine-scarlet.

Oz., 20c; Pkt., 10c

LORD NELSON-Dark navy blue.

Oz., 20c; Pkt., 10c

HON. MRS. E. KENYON-Clear buff-yellow.

Oz., 20c; Pkt., 10c

EARLY FLOWERING ORCHID or SPENCER-

All colors mixed. These blooms four weeks earlier than other Sweet Peas and if kept picked will continue to flower for three months; waved and frilled flowers on long stems. Oz., 25c; Pkt., 10c

VERBENA, MAM MOTH - The Verbenna is one of the most popular garden annuals. They bloom profusely the first year from seed, the flowers lasting until late in autumn. Mixed colors.

$$
\text { Oz., \$1.00; Pkt., 5c }
$$

ZERANTHEMUM-One of the best of the everlasting flowers. A choice mixture of colors, including purple, light rose and white; very showy in the garden, and can be dried for winter bouquets.

Oz., \$1.00; Pkt., 5c

ZEA (Rainbow Corn)-A varitey of maize with leaves variegated yellow, green rose and dark red., Four feet.

$\mathrm{Oz} ., 25 \mathrm{c}$; Pkt., 5c

ZINNIA (Double Dahlia Flowered)-A beautiful new type closely resembling decorative dahlias in form and in the arrangement of the petals. They attain a height of 3 feet, producing large blooms of distinctive colorings.

Oz., \$2.00; Pkt., 10c

BLACK KNIGHT-Very dark red, one of the darkest and richest colored of Zinnias. Flowers two and one-half to three inches in diameter; very thick and double. This flower always attracts attention by its intense coloring and perfect flowers.

Oz., \$1.75; Pkt., 10c 


\section{Planet Jr. Tools}

Planet Jr. tools save time, lighten labor, and get bigger, better crops at less cost. Designed by a practical farmer and manufacturer with over 40 years experience. Lasts a lifetime. Fully guaranteed.

No. 3 PLANET JR. HILL AND DRILL SEEDER

Holds 3 quarts of seed.

A favorite among onion growers, market gardeners and seedsmen.

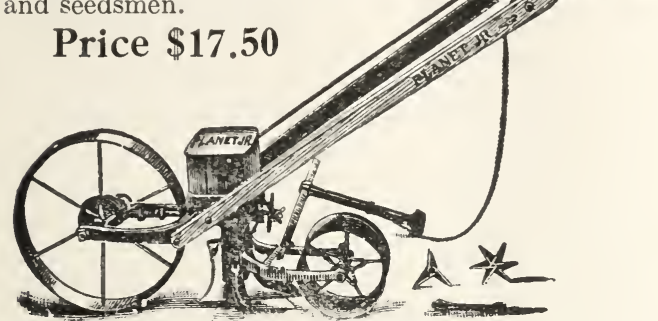

Sows accurately in large or small quantities in drills in a narrow line, making wheel-hoe cultivaticn easy, or in hills, $4,6,8,12,24$ inches apart. Force feed.

The flow of seed is instantly started or stopped by the cut-off rod. No seed wasted at ends of rows.

$$
\text { No. } 107
$$

\section{PLANET JR. SEVEN-TOO'TH PLAIN GULTIVATOR}

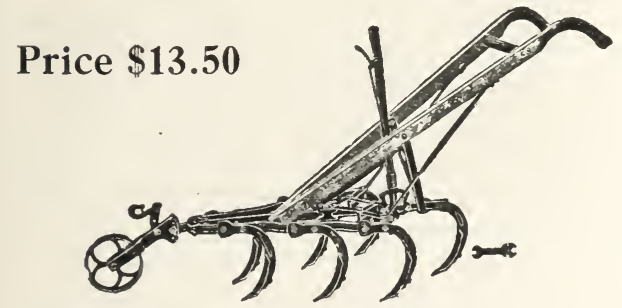

This cultivator is very much like the No. 101, but has seven teeth. It does closer and finer work than the fire tooth. The DEMAND TUDAY IS FOR BETTER CULTIVATION, FINER, CLOSER WORK and SURER DESTRECTION TO WEEDS. The Planet Jr. No. 197 7-tooth Plain Cultivator is meeting this demand for many farmers.

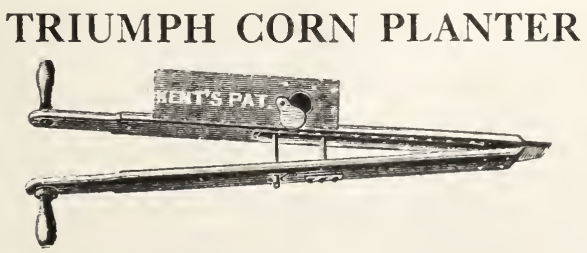

We carry the Triumph Corn Planter with Fertilizer Attarhment. Price $\$ 2.25$ Each.
No. 12 PLANET JR. DOUBLE WHEEL
HOE CULTIVATOR and PLOW

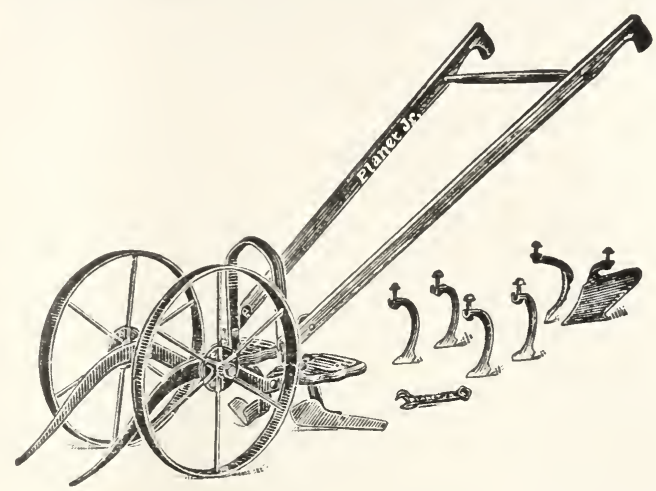

A single and double wheel hoe in one. Straddles crops till 20 inches high, then works between. Has steel frames and 14-inch steel wheels. The greatest hand cultivating tool in the world.

\section{Price $\$ 10.75$}

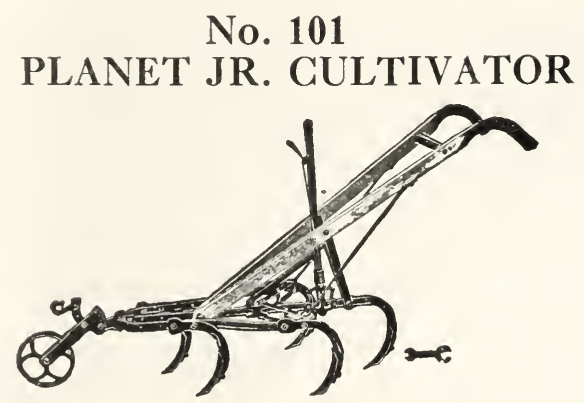

A new and improved cultivator sold at a low price. Stop in and see it. It will please you. The No 101 is simple, strong and easily handled and has so few wearing parts that it will give many years of service with an occasional replacement of teeth.

\section{Price, with Wheel $\$ 11.75$}

\section{RUBBER BANDS}

We carry in stock Rubber Bands for bunching, No. 7 and No 8 best grade and also all kinds of strings for bunching. 


\section{Special Notice}

We make a specialty of supplying Market Gardeners with the best strains of seeds that can be produced. We are always on the alert for a better strain, and if we find it, we spare no expense in securing stock of it. We handle absolutely nothing that we do not believe to be the best obtainable. We do not claim to compete in prices with irresponsible parties, whose sole effort is to secure the lowest priced seeds, regardless of quality; such seeds are not cheap, but dear at any price. The first cost of seeds is insignificant, compared with time and labor that must be expended upon a growing crop. Quality is our first consideration, and the prices we offer are as low as first-class seeds can be sold for.

\section{Will You Please}

\section{Send Us Your Order as Soon as Possible?}

Our purpose in requesting this is because we want to give you the best possible service and we are able to do this the more easily when you ORDER EARLY. There is sure to be a rush of orders as spring approaches and by ordering now your order can be taken care of promptly before this rush begins. Then, too, there are a few items of which our supply will be low because of partial failure of the seed crop. Our stock of these items will probably be sold out before planting time. Why not make up your order today and mail it in to us? You can then be sure of securing all the varieties ordered and it will help us give you better service.

C. J. LINDHOLM.

\section{INDEX}

\begin{tabular}{|c|c|c|}
\hline Page & $\mathrm{Pa}$ & 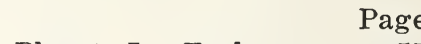 \\
\hline$\ldots \ldots 45$ & Field Corn .. & Planet Jr. Tools. \\
\hline Asparagus $\ldots \ldots \ldots \ldots .9$ & Field Peas ......... 46 & Popcorn ......... \\
\hline Asparagus Roots...... 48 & Flax $\ldots \ldots \ldots \ldots \ldots 46$ & Radish...6 and 7 and $3 \varepsilon$ \\
\hline Bets........ $10-11$ & Fodder Corn ... & Red Top \\
\hline eans......7 and.12-13-14 & Flower Seeds .. & Rhubarb Roots \\
\hline orage ............ 19 & Flowering Plants ..... 48 & Rape \\
\hline roccali ........... 14 & Garlic ............. 44 & abaga \\
\hline sels Sprouts....... 14 & otkaps ............ 49 & \\
\hline neat $\ldots \ldots \ldots \ldots 46$ & ale $\ldots \ldots \ldots \ldots \ldots 22$ & sh. \\
\hline e $\ldots \ldots 7$ and $15-16$ & Rabi ........ 44 & Soy Beans ........ \\
\hline wer ......3 and 17 & ucky Blue Grass.... 45 & Sun Flower \\
\hline$\ldots \ldots \ldots \ldots 17$ & $\ldots \ldots \ldots \ldots \ldots \ldots 44$ & Sugar Cane \\
\hline hinese Cabbage....... 24 & Lawn Grass Seeds.. & n Grass \\
\hline t. . . . 2 and 18-19 & Lettuce . . . . . . . 25-26 & mer Savary ... \\
\hline$\ldots \ldots \ldots \ldots \ldots \ldots 45$ & Melon....4 and 27-30 & Squash........5 and \\
\hline Collards .......... 22 & d ........... 22 & Sweet Marjaram ...... \\
\hline elle ........... 3 & $\ldots \ldots \ldots 46$ & Swiss Chard ...... \\
\hline er....2 and $20-21$ & $\ldots \ldots \ldots \ldots \ldots 33$ & to......8 and 42 \\
\hline orn. . 1 and 22-23-24 & n. ...2 and 4 and $32-33$ & e $\ldots \ldots \ldots \ldots \ldots$ \\
\hline$\ldots \ldots \ldots \ldots \ldots 19$ & os $\ldots \ldots \ldots \ldots 34$ & thy \\
\hline$\ldots \ldots \ldots \ldots \ldots 44$ & ey......8 and 34 & \\
\hline gg Plant ......... 24 & $\ldots \ldots \ldots$ and $36-37$ & able Plants \\
\hline ndive $\ldots \ldots \ldots \ldots . . \ldots 24$ & Pepper.........3 and 35 & Watermelon..2 and 5 and \\
\hline
\end{tabular}




\section{A Page of Our Specialties That Have Exceptional Merit}

\section{BEET}

DETROIT DARK RED-The beets are of perfect globe shape with small tops and fine tap roots. The color is deep red without light colored rings. The quality is exceptionally fine.

\section{CARROT}

RICE'S CORELESS-A very handsome early carrot, roots a deep orange color, richly colored clear through. Free from hard, woody core and of excellent quality. Six to 7 inches long, cylindrical and stump rooted.

\section{CAULIFLOWER}

SNOWDRIFT-One of the best for early and late. A compact grower and sure header. The leaves are plenty large enough to afford protection to the head. It is rapidly taking the place of many of the older selections on account of its fine texture, pure white heads and large size. Sure heading even under unfavorable conditions.

\section{CUCUMBER}

LONGFELLOW-Highly desirable either for greenhouse or outdoor growing. Fruits 11 to 12 inches long as slicers, some longer. Uniform in size, shape, color and quality. Very dark green and holding its color a long time. Requires rich soil and the best of culture.

\section{CABBAGE}

FERRY'S HOLLANDER-This is one of the most largely grown varieties for fall shipping and winter keeping. It is round and solid. Grows well on all soil and resists most any kind of weather. Has few outside leaves.

\section{SWEET CORN}

EARLY SUNRISE-A money maker for market growers who wish to be first on the market. Nearly two weeks earlier than Golden Bantam, and while hardly as sweet the quality is better than most extra early sorts. The plump yellow kernels set 8 to 10 rows to the cob.

\section{TENDERGREEN BEAN}

This new variety has nroved to be one of the very best green beans with round pods. The pods are long, rather slender, light green, round as a pencil, stringless and of very high quality, being unusually tender and delicious when cooked. The vines are very vigorous, strong and productive. The pods mature about the same time as Black Valentine and much resemble that variety in appearance but are far superior in quality.

\section{GOLDEN OSAGE MUSKMELON}

We believe there is no muskmelon quite equal to the Golden Osage for fine flavor, size and keeping qualities combined.

\section{WATER MELON}

BLACK SEEDED A N G E L I N O-A new variety. The color of the flesh a deep crimson. The flavor is exceptionally fine and it is highly recommended for the home yarden and roadside market.

\section{PEAS}

WORLD'S RECORD-An improved Gradus, being a little earlier and larger and has shorter vines. It is of the finest quality and a profitable variety for market.

\section{RADISH}

SCARLET GLOBE-Transplanted stock. We offer three distinct strains of this most important sort.

RESELECTED SCARLET GLOBE-Standard type.

SCARLET GLOBE 11-Special outdoor strain with more top.

BRIGHT SCARLET GLOBE-Special greenhouse stock.

\section{TOMATO}

BREAK O' DAY-A new wilt resistant tomato that is nearly as early as Earliana and as productive as Marglobe. Its fruits are large, smooth, meaty, red and globular. 


\section{LINDHOLM'S}

High Grade Northern Grown Seeds suited to all Soils and Climates as they are Northern Grown

SEEDS that Satisfy

BULBS that Bloom

PLANTS that Grow

Our Floral Specialties are PEONIES,

DELPHINIUMS,

GLADIOLUS

and DAHLIAS

This catalogue does not include all the seeds we handle. Write or phone ...... We will supply any variety you wish.

\section{CHAS. J. LINDHOLM}

High Grade Seeds for Truck Gardeners and Florists

Residence:

4133 Lyndale Avenue No.

Res. Phone: Hyland 1966
Retail Store:

4170 Washington Ave. No. Bus. Phone: Hyland 7424

Minneapolis, Minn. 